JULIE M. POLAKOSKI

THE IMPACTS OF GOOD FAITH ON COLLECTIVE BARGAINING:

A NEW ZEALAND CASE STUDY

LLM THESIS

LAWS 582: LLM BY THESIS

FACULTY OF LAW

TE WHARE WĀNANGA O TE ŨPOKO O TE IKA A MĀUI

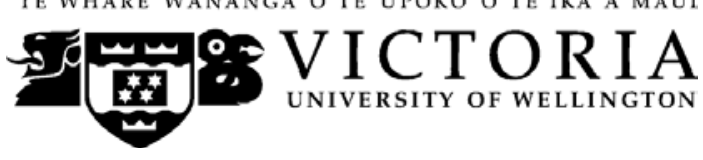

$2010-2011$ 


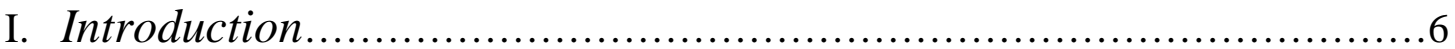

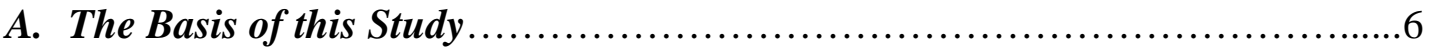

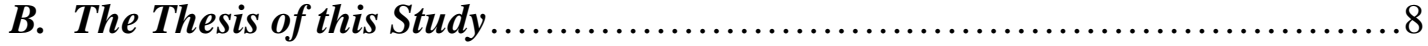
C. Research Question......................................................... 10

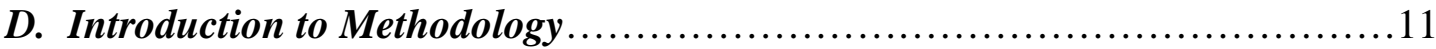

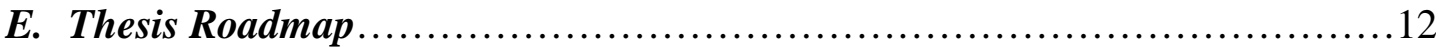

II. Background Information On New Zealand Employment Law.............14

A. Historical Background........................................................

1. Introduction.............................................................. 14

2. The Industrial Conciliation and Arbitration Act of 1894 and Its Legacy...........15

3. The Employment Contracts Act of 1991 and Its Legacy..........................18

4. The Law of the Day: The Employment Relations Act of 2000......................22

5. Conclusion regarding New Zealand's Employment Law History..................24

B. The ERA's Duty of Good Faith in Collective Bargaining.........................25

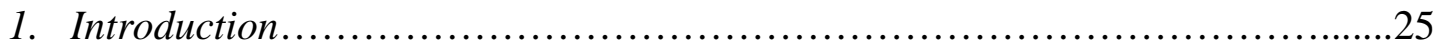

2. Basic Good Faith Bargaining Requirements.................................26

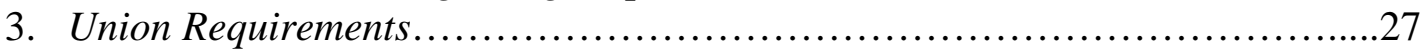

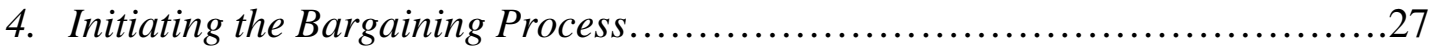

5. Bargaining Process Agreements (BPA).....................................29

6. Meeting and Presenting Collective Agreement Requirements.....................30

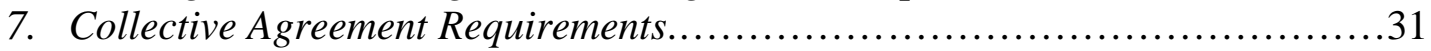

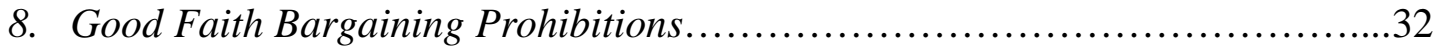

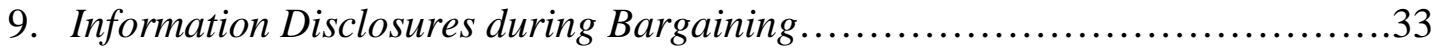

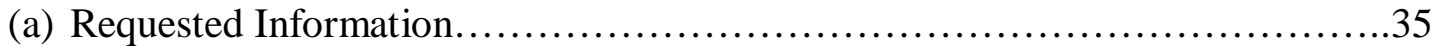

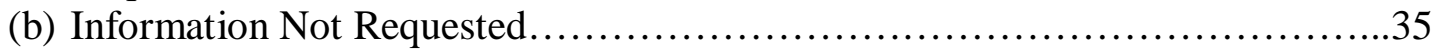

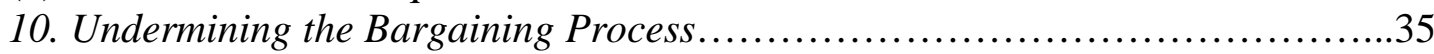

(a) Communication with Employees During Negotiations.........................36

(b) Sending uninformed representatives to the bargaining table.....................37

(c) Dragging out the bargaining process or unnecessarily rushing through the

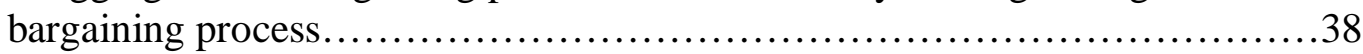

(d) Inaccurately informing constituents or failing to inform constituents of the progress and offers being made during bargaining............................38

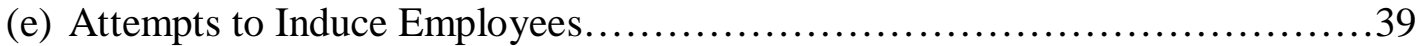

(f) Passing on the collective terms and conditions of employment to non-union

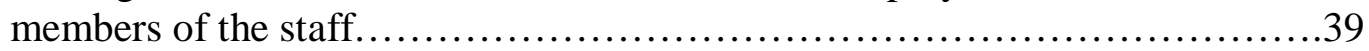

11. Unilaterally ending collective bargaining ...................................42

12. Statements to the public, third parties, or media.............................42

13. Trade Union Education Leave...............................................42

14. Bargaining Fee Agreements..............................................42

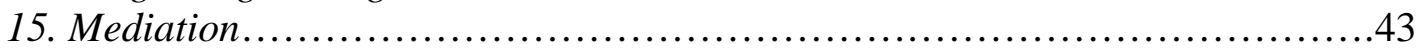

16. Requirement to Conclude a Collective Agreement.............................45

17. Post Bargaining Requirements................................................45 
18. Economic Weapons Available: The Ability to Strike or Lockout...................46

19. Breach of Good Faith.......................................................48

C. Discussions about the Impacts of Good Faith in Collective Bargaining ........49

1. Introduction to Discussions about Good Faith.......................................49

2. Early Support for Good Faith and a Comparative Perspective....................50

3. Literature Challenging the Effectiveness of Good Faith in Collective

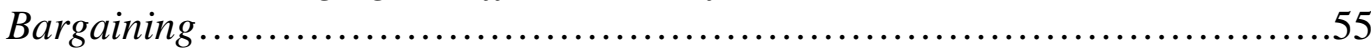

4. Conclusion of Commentators on Good Faith..................................63

III. The Current State of Collective Bargaining in New Zealand.............64

A. Introduction to the State of Collective Bargaining Statistics....................64

B. The Public-Sector and Private Sector Divide ..................................65

C. The Current State of Collective Bargaining in New Zealand..................66

D. The Significance of the Current State of Collective Bargaining in New Zealand.................................................................66

IV. Background Information of the Results...............................67

A. The Value and Focus of this Interview-Based Study .......................67

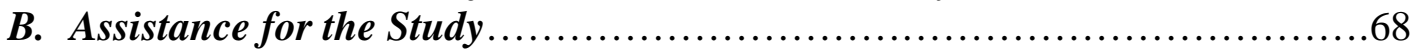

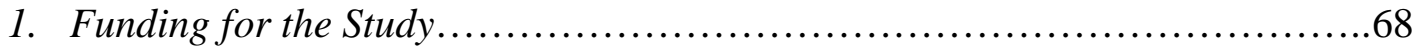

2. Supervisory Assistance, Advice, and Review.................................68

3. External advice..............................................................69

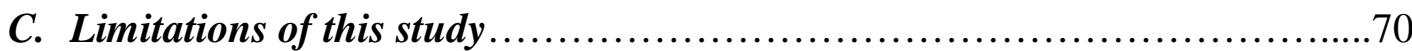

1. Time and Administrative Restrictions.........................................70

2. Scope limited to the Employment Relations Act, subsequent laws regulating good faith in collective bargaining, and the Code of Good Faith.......................70

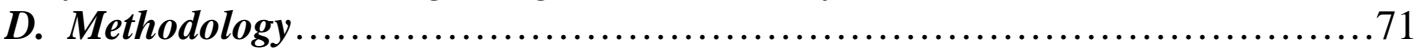

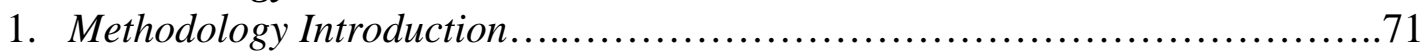

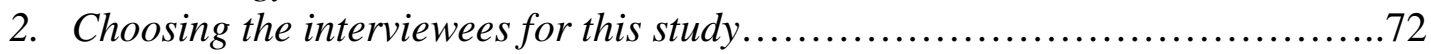

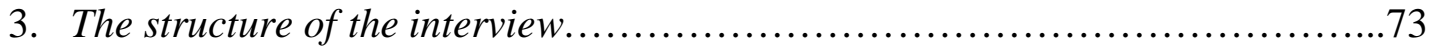

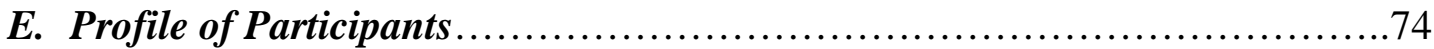

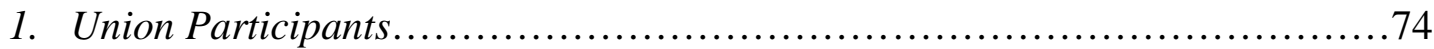

(a) The Service and Food Workers Union Nga Ringa Tota.........................74

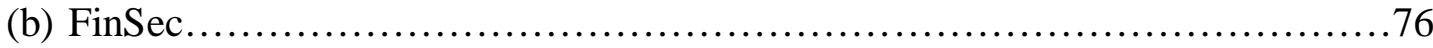

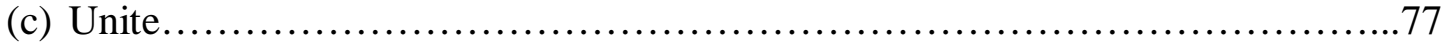

(d) The New Zealand Amalgamated Engineering, Printing and Manufacturing

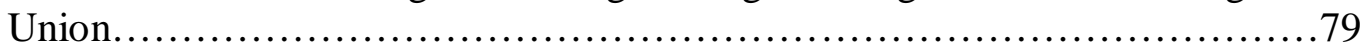

(e) The New Zealand Tramways and Public Passenger Transport Employees

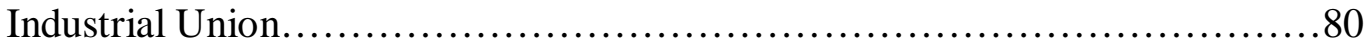

(f) The New Zealand Tertiary Education Union................................... 81 


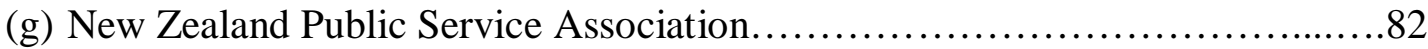

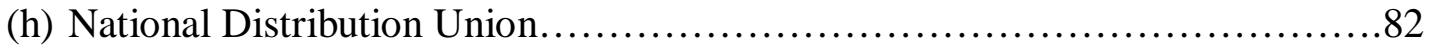

(i) New Zealand Meat Workers \& Related Trades Union Inc.......................84

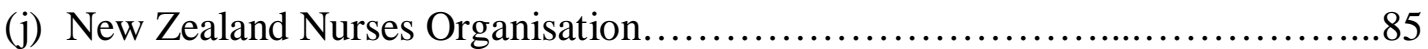

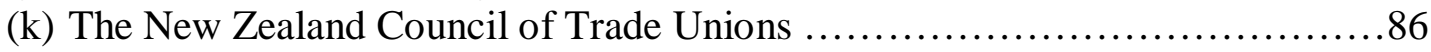

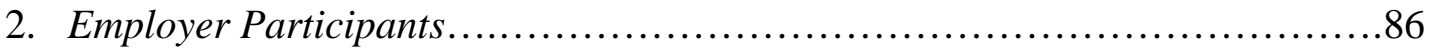

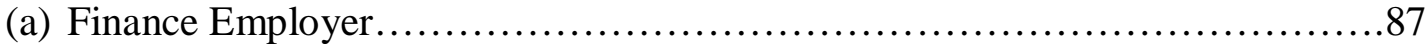

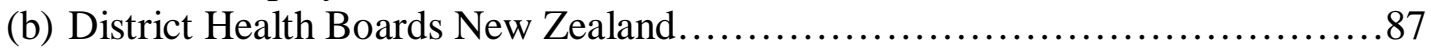

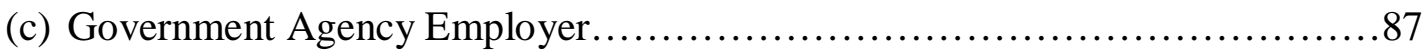

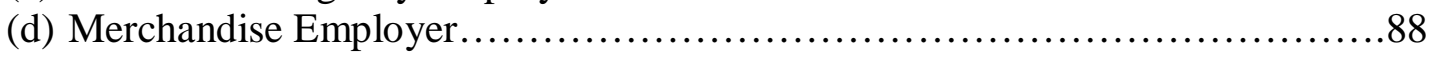

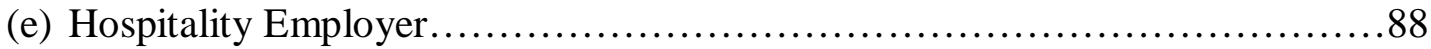

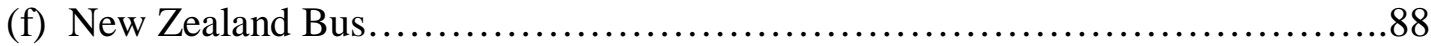

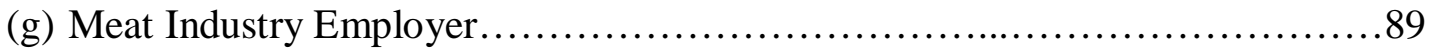

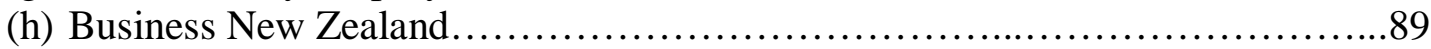

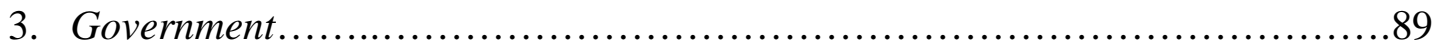

(a) New Zealand Department of Labour Mediation Service...........................89

(b) New Zealand Department of Labour .........................................90

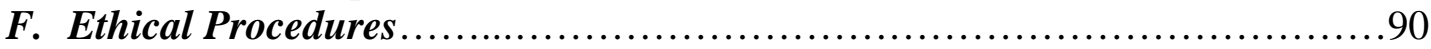

G. The quantity of interviews conducted for this study.........................91

V. The Interviews with the Parties to Collective Bargaining ...............91

A. Bargaining Process Agreement (BPA).......................................992

1. BPAs Where the Union and Employer Have a Good Relationship................92

2. BPAs where the parties do not have a good relationship and general problems with the BPA Requirement.................................................96

3. Positive Feedback regarding the BPA Requirement...........................100

4. Conclusion Regarding the BPA Requirement................................101

B. Collective Bargaining Process.............................................102

1. Opinions of unions regarding the duty of good faith in collective bargaining...103

2. Employer opinions about the impacts good faith in collective bargaining.......107

3. Conclusion Regarding Good Faith in Collective Bargaining.....................110

C. Information Requests and Disclosures during Bargaining....................110

1. Employers' opinions regarding information requests and the flow of information during bargaining.........................................................111

2. Unions' opinions regarding information requests and the flow of information during bargaining ..........................................................114

3. Conclusion regarding the interviewees' experience with information requests and disclosures made during bargaining..........................................115

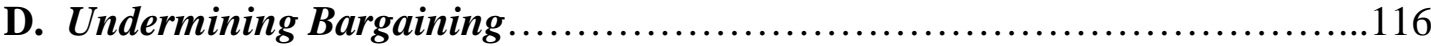

1. Introduction................................................................116

2. Direct Communications with Employees During Bargaining, Keeping Employees Informed about Bargaining Progress and Attempts to Induce Employees.......117

a. Employers' experiences with employee communications made during bargaining.............................................................. 118

b. Unions' experiences with employee communications made during bargaining. 
c. Conclusion regarding communications made to employees during bargaining.

3. Sending uninformed representatives to the bargaining table....................125

4. Continuing Bargaining after Reaching an Impasse on an Issue................126

5. Protracted Bargaining..................................................... 128

6. Passing on the collective terms and conditions of employment to non-union members of the staff.......................................................129

a. Union opinions regarding passing on......................................

b. Employer Opinions Regarding Passing-On................................133

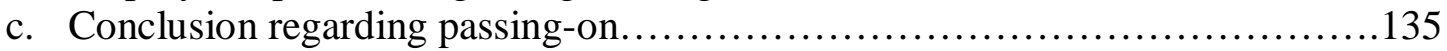

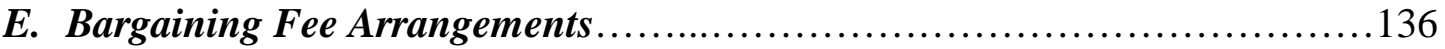

F. Requirement to Conclude a Collective Agreement..........................138

1. Employer Opinions Regarding the Duty to Conclude an Agreement..............139

2. Union Opinions Regarding the Duty to Conclude an Agreement....................140

3. Conclusion Regarding the Duty to Conclude an Agreement......................143

G. Post-Bargaining Requirements...................................... 143

H. Breach of Good Faith Remedies......................................... 145

1. Seeking a Legal Remedy................................................ 145

VI. Analysis.............................................................. 148

A. Common Themes....................................................... 148

1. Good Relationship Significant Factor for Collective Bargaining..................148

2. High Union Density Significant Factor for Collective Bargaining................150

(a) Union Opinions of the Benefits of High Density to Collective Bargaining......150

(b) Employer Opinions of the Benefits of High Density to Collective

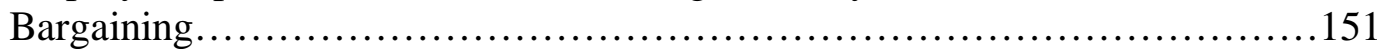

(c) Conclusion Regarding High Union Density.............................. 152

VII. Conclusion.............................................................. 152 
Thank you to my parents for inspiring my study of labour relations and to my Fulbright family for bringing me to New Zealand and supporting me along the way. 


\begin{abstract}
This paper explores the protective strength of the good faith reforms as enacted under the Employment Relations Act 2000 and subsequent legislation on the collective bargaining rights of workers. Interviews were conducted with numerous unions and employers in New Zealand to discover how the good faith reforms have impacted their dealings with one another with regards to collective bargaining.

\section{Word length}

The text of this paper (excluding abstract, table of contents, footnotes and bibliography) comprises approximately 45,894 words.
\end{abstract}

\title{
Subjects and Topics
}

Employment Law or

Labour Law or

Employment Relations Act 2000 


\section{Introduction}

\section{A. The Basis of this Study}

New Zealand is a country of dynamic employment reform. Throughout the past decades, New Zealand has moved from one of the most heavily regulated labour markets to one of the least regulated. Today, a change in government can often mean a change in the employment laws. However, the real impact of these legal reforms on the collective bargaining rights of workers is an area yet to be fully explored.

For almost a century beginning in 1894, New Zealand had one of the most union protectionist employment law systems in the world. ${ }^{1}$ For some time, not only did the law give unions a great deal of statutory strength, but trade union membership was effectively compulsory for employees whose work was covered by a union. ${ }^{2}$ Very little regarding workers' employment terms was left to the flow of the free market; awards extending to workers in an industry throughout the nation set minimum terms and conditions of employment. $^{3}$

However, in 1991, the National Party abolished all legal protections for unions and the collective bargaining process through the enactment of the Employment Contracts Act (ECA). The ECA took a hands-off, free market approach to labour management. Trade unions were no longer recognized as industrial entities or organisations of employees under the law, and the ECA provided little protection against anti-union tactics engaged in by employers. The ECA's deregulation of New Zealand labour lasted for nine years, resulting in a dramatic decrease in collective bargaining coverage throughout the country.

\footnotetext{
${ }^{1}$ Ellen J. Dannin “We Can’t Overcome? A Case Study of Freedom of Contract and Labor Law Reform” (1995) 16(1) Berkeley J. Empl. \& Lab. L. 3 at 4.

2 Gordon Anderson “Just a Jump to the Left? New Zealand's Employment Relations Act 2000” (2001) 14 AJLL 62 at 68.

${ }^{3}$ Dannin, above $n 1$, at 4.
} 
In 2000, a Labour government attempted to yet again change the direction of New Zealand's employment laws by bringing back protections for workers to collectivise. Unlike the ECA, which assumed that unions and employers have equal power at the bargaining table, the Employment Relations Act 2000 (ERA) recognizes the inequality of power in employment relationships. ${ }^{4}$ The ERA attempts to address this inequality by binding parties to a duty of good faith.

The duty of good faith is now the centrepiece of New Zealand's industrial relations management system. Unlike the ECA that defined the employment relationship as a mere contractual relationship, the ERA categorizes the employment relationship as a "human relationship" involving issues of "mutual trust, confidence, and fair dealing." The ERA seeks to build productive employment relationships by requiring the parties to engage with one another in good faith. ${ }^{5}$ Accordingly, the parties to collective bargaining are now obligated to be responsive, communicative, open, and honest in their relations with one another. Good faith requires unions and employers to engage in "cooperative and facilitative methods of resolving bargaining disputes” instead of being adversarial. ${ }^{6}$

One of the stated goals of the ERA is to promote collective bargaining. However, 10 years into the ERA, collective bargaining coverage remains at the same low rate as it was during the ECA and continues to decline. Consequently, the ability of good faith to safeguard collective bargaining is being questioned.

New Zealand has progressed from a system that provided no protections for collective bargaining to a system that now relies on the duty of good faith to protect and promote collective bargaining. In engaging in these dramatic labour reforms over the course of several decades, New Zealand has provided insight to the rest of the world of the impacts of the law on collective bargaining. 10 years into its inclusion in New

\footnotetext{
${ }^{4}$ Employment Relations Act 2000, s 3.

${ }^{5}$ Richard Rudman Employment Law Guide (2010 ed, CCH, Auckland, 2010) at 89.

${ }^{6}$ Ibid, at 97; see Assn of University Staff Inc v Vice Chancellor of the University of Auckland [2005] 2 NZELR 277, [2005] 2 (1) NZLR 277.
} 
Zealand employment law, New Zealand becomes a useful case study of the effectiveness of the duty of good faith in collective bargaining.

Discovering the impacts of legal reforms on collective bargaining is important for purposes of understanding how to protect workers' rights. ILO Conventions 87 and 98 encourage independent unions and collective bargaining to help even out the power imbalance that exists between unions and employers. ${ }^{7}$ Collective bargaining is recognized by the international labour law community as an effective tool to protect those in weak bargaining positions. Collectivization is also viewed as a means for overcoming any power imbalance between employers and employees that may result in unjust employment terms and conditions. Thus, research of this nature in countries such as New Zealand can shed light on the value of the duty of good faith and how the law can effectively protect collective bargaining.

\section{B. The thesis of this study}

The thesis of this study is that the duty of good faith is not an effective means under the law to promote or protect collective bargaining. To prove this thesis, New Zealand was used as a case study involving the parties bound by the duty of good faith in collective bargaining.

This thesis is supported by empirical research gathered by the author. Interviews were conducted with unions and employers regarding their experiences with good faith in collective bargaining under the ERA. Some interviewees participating in this study who worked in the area of labour management relations in the 1990s were able to compare their experiences with collective bargaining under the ERA to their experiences with collective bargaining under the ECA. However, all union and employer participants

\footnotetext{
${ }^{7}$ Geoff Davenport and Judy Brown Good Faith in Collective Bargaining (LexisNexis Butterworths, Wellington, 2002) at 21; see Freedom of Association and Protection of the Right to Organise Convention ILO C87, 31st conf, (1948); see Right to Organise and Collective Bargaining Convention ILO C98, 32nd conf, (1949).
} 
contributed their opinions as to whether good faith has helped collective bargaining over the past 10 years since the ERA became law.

These comments affirmed the premise of this paper. Union and employer interviewees expressed that good faith has done little to meaningfully alter their behaviour during bargaining or significantly improve bargaining outcomes. Ultimately, the research conducted with these parties revealed that the protective strength of the duty of good faith is minimal and the state of collective bargaining has not been substantively improved by the good faith reforms. The findings gathered from these interviews should be reflected upon in light of the current trend of declining collective bargaining coverage in New Zealand.

While this paper whole-heartedly concedes that good faith has a very important role in modern employment law, good faith is not considered, in and of itself, adequate to promote or protect collective bargaining. Therefore, enacting a law in which the duty to act in good faith is the primary protection is not sufficient to promote collective bargaining.

\section{Research Question}

New Zealand's law that first enacted the duty of good faith, the Employment Relations Act of 2000, was dissected to investigate the impacts of good faith in collective bargaining. Rather than doing an economic analysis of the impacts of these legislative reforms or a statistical study of union density since the enactment of the ERA, the main research gathered for this study investigated the human side of the good faith employment reforms.

The main research question of this paper is whether the duty of good faith has improved collective bargaining according to the experiences of unions and employers. 
To find an answer, interviews were conducted with many of these parties of collective bargaining from various industries and sectors.

Interviewees were asked questions seeking to reveal the effectiveness of the duty of good faith in collective bargaining. An understanding of the following was sought:

- Whether good faith is effective in evening out the power discrepancy between employers and unions during collective bargaining

- $\quad$ Whether good faith facilitates the collective bargaining process towards a fair settlement.

- $\quad$ Whether good faith can remedy a situation in which bargaining negotiations have broken down or become tense

- Whether good faith can protect workers from being discouraged from collectivising due to employer intimidation and other anti-union tactics

The interviewees volunteered information on their experiences regarding individual good faith provisions under the ERA in addition to their opinions about the state of collective bargaining as a whole under the duty of good faith.

\section{Introduction to Methodology}

Over the course of ten months, interviews were conducted in New Zealand with the parties involved in collective bargaining - employers and unions. Interviewees were asked for their opinions and experiences surrounding good faith under the decade-old Employment Relations Act in attempt to discover whether good faith has been effective or beneficial.

These interviews investigated the extent to which parties to employment agreements are conducting their interactions with one another in accordance with the duty to bargain in good faith. The impacts of this duty on the collective bargaining process were explored. 
Specifically, the interviews for this study sought to reveal whether or not the duty of good faith was benefitting the overall collective bargaining process and resulting settlement according to unions and employers. Interviewees were asked which good faith provisions have benefitted the collective bargaining process, which provisions have done nothing, and whether or not good faith as a whole has improved collective bargaining outcomes. Additionally, the interviewees were questioned, in their experience, whether the good faith provisions have actually promoted collective bargaining.

While most of the comments in this study are subjective opinions of trade unionists, employers, and their respective interest groups about their experiences with good faith, there were significant trends in the opinions offered for this study.

Accordingly, these opinions are valued for purposes of understanding the impacts of New Zealand employment reforms on the parties directly involved in employment relations, day-in and day-out. What these opinions and comments revealed is that although the ERA has now been around longer than the ECA, its impacts have not been as strong as its predecessor; in fact, the ERA has yielded similar results and experiences as the ECA with regards to collective bargaining coverage.

The interviews of this study revealed that the main goal of the ERA to promote collective bargaining by encouraging productive good faith employment relationships has not yet been achieved; however, its other aims - to protect individual choice, keep judicial intervention at a minimum, and promote mediation - have been realised. Because good faith is not an effective means of promoting collective bargaining under the law, New Zealand's original expectations to create a shift in employment relations were misplaced as collective bargaining coverage continues to decline.

\section{E. Thesis Roadmap}

This thesis will begin by providing a general summary of New Zealand's employment law history. This information gives context to the current law and shows the significance of the legislative reforms over the past few decades. How New Zealand has 
approached the regulation of its industrial relations system throughout its history also helps explain the impacts the current legislation had on industrial relations.

Following a discussion of New Zealand's employment law history, this paper will list the current good faith requirements of the Employment Relations Act 2000 and the Amendment Act 2004. This section will outline what is expected from unions and employers in order to comply with the duty of good faith in collective bargaining under the ERA. The results provided in this study will build off of what is required of the parties to collective bargaining.

The arguments made by scholars and experts in New Zealand employment relations will then be provided to show the context of this study. This discussion aims to show how this study has picked up from where other literature on the topic has left off, and how this study will hopefully contribute to the discussions of the impacts of legislative reforms on collective bargaining.

The current state of collective bargaining in New Zealand will follow. This section of the paper presents the collective bargaining rates existing in New Zealand after the past few significant legislative reforms. The research conducted for this study attempts to explain the statistics discussed in this part of the paper.

All of the background information provided in this paper up until this point seeks to build a solid foundation of collective bargaining in New Zealand. This foundation sets the stage for the presentation of the empirical research gathered by the author of this study.

The logistics behind the interviews conducted to prove this thesis including who participated and how the interviews were conducted is then described. This methodology section introduces the results. 
The results of the interviews conducted by the author of this paper simply highlight unions' and employers' experiences with good faith in collective bargaining. The information following the results attempt to make some conclusions about what their comments mean in interpreting the impacts of the good faith reforms in New Zealand on collective bargaining. Most importantly, the results prove the thesis of this paper: the duty of good faith is not an effective means under the law to promote or protect collective bargaining.

\section{BACKGROUND INFORMATION ON NEW ZEALAND EMPLOYMENT LAW}

\section{A. Historical Background}

\section{Introduction}

For most of its history, New Zealand Employment law has focused on promoting unionisation and the collective determination of terms and conditions of employment. New Zealand became the first country in the world to legalize the collective determination of terms and conditions for workers when it enacted the Industrial Conciliation and Arbitration Act of 1894 (IC\&A Act). ${ }^{8}$ The IC\&A Act created the foundational framework for New Zealand's employment law system that remained in place until the late $20^{\text {th }}$ century. ${ }^{9}$

By the 1990s, New Zealand had radically reformed its laws to move as far away from the system established by the IC\&A Act as possible. However, by 2000, New Zealand embarked upon another legislative reform towards a more moderate approach to industrial relations management. A brief history of New Zealand employment law is helpful to understanding the nature of the impacts of its current law on collective bargaining and unionisation.

\footnotetext{
${ }^{8}$ Dannin, above n 1, at 9-10.

${ }^{9}$ Gordon Anderson "New Zealand" in R. Blanpain (ed) International Encyclopaedia of Laws (Kluwer Law International, Alphen aan den Rijn, 2006] 1 at 22.
} 


\section{The Industrial Conciliation and Arbitration Act of 1894 and Its Legacy}

The 1894 IC\&A Act's title stated that its purpose was "to encourage the formation of industrial unions and associations and to facilitate the settlement of industrial disputes by conciliation and arbitration." ${ }^{10}$ The IC\&A Act required that industrial disputes be resolved through compulsory arbitration. The arbitration mechanisms in place set minimum, legally enforceable terms and conditions of employment for most industrial and even white-collared workers throughout New Zealand. $^{11}$

The IC\&A Act's arbitration system gave unions much statutory strength. First, unions registered under the Act were given 'exclusive jurisdiction' in an industry; this meant that the registered union for an industry was the exclusive voice of the workers in that particular industry. ${ }^{12}$ The registered union was given jurisdiction over all of the persons working under the occupational description provided in the registration, in all the geographic areas specified in the covered industry. ${ }^{13}$ All unions and employers in a covered industry were then bound to the terms of the award negotiated by the registered union with its respective employers. ${ }^{14}$

Employers were required under the IC\&A Act to recognize and bargain with the respective registered union in their industry, providing unions with power independent of strikes. ${ }^{15}$ Further, to also promote industrial peace, the IC\&A Act set forth procedures for settling disputes and enforcing industrial agreements. ${ }^{16}$ Strikes and lockouts were illegal where an award was in force, also ensuring less volatile industrial action. ${ }^{17}$

\footnotetext{
${ }^{10}$ Erling Rasmussen Employment Relations in New Zealand (2nd ed, Pearson, North Shore (New Zealand), 2009) at 51; see Industrial Conciliation and Arbitration Act 1894.

${ }^{11}$ Anderson, above n 9, at 22 and 46.

12 Erling Rasmussen Employment Relations in New Zealand (2nd ed, Pearson, North Shore (New Zealand), 2009) at 52; see also Dannin, above $n 1$, at 9-10.

${ }^{13}$ Dannin, above n 1 , at 9-10.

14 Ibid, at 10 .

${ }^{15}$ Rasmussen, above n 12, at 52.

${ }^{16}$ Ibid, at 53.

17 Ibid.
} 
Although New Zealand reformed its employment laws numerous times as government administrations changed, the foundations of this compulsory arbitration and national awards system remained in place for most of the $20^{\text {th }}$ century. Accordingly, most of the collective bargaining that took place from 1894 until 1991 was on a multiemployer basis, resulting in awards that set minimum terms for workers falling under its coverage. $^{18}$

More specifically, the principles upon which New Zealand based its industrial relations system remained the same for almost 100 years. ${ }^{19}$ The primary principles,

...were the encouragement and involvement of unions, the belief that basic terms and conditions are best set by the collective involvement of workers, and finally that such terms and conditions should extend to the whole workforce. ${ }^{20}$

Until the 1990s, the changes made to New Zealand's employment laws only reformed the processes to deliver these principles, and were implemented within the existing national awards system that had first been established in 1894 with the IC\&A Act. ${ }^{21}$

The high degree of legal protections in place for unions until the 1990s affected how unions operated. Unions did not need to and could not compete for members because representation was defined through registration. Registration also ensured such membership indefinitely and legally compelled the payment of dues. ${ }^{22}$ By the 1980s, the rigid controls on the labour market meant that a union represented most workers. Also by this time, these unions had held exclusive jurisdiction over their respective industries for almost a century, with a legally enforceable collective agreement in place for nearly as long as well. ${ }^{23}$

\footnotetext{
${ }^{18}$ Dannin, above $\mathrm{n} 1$, at 11 .

${ }^{19}$ Anderson, above n 9, at 49.

${ }^{20}$ Ibid.

${ }^{21}$ Ibid.

${ }^{22}$ Dannin, above $\mathrm{n} 1$, at 12.

${ }^{23}$ Ibid; see also Gordon Anderson "Developments in the Legal Regulation of Collective Bargaining in New Zealand” (1990) 3(3) AJLL 227 at 228.
} 
Furthermore, the national awards system also limited unions' experiences with collective bargaining. ${ }^{24}$ Because awards set minimum conditions, employers were legally allowed to unilaterally make the terms and conditions better without the union's involvement; in fact, it became common practice for the union not to participate when the employer addressed workplace issues or raised the standards for its unionised workers. ${ }^{25}$ A study conducted in 1990 found that only 15 per cent of employers discussed their above-award increases with either the union or employees involved. ${ }^{26}$ Accordingly, even though unionisation remained quite high, unions were not necessarily actively involved in their collective agreements or representing their members. ${ }^{27}$

By the 1980s, an economic recession caused New Zealand's legislators' to turn their attention to potential labour reform. ${ }^{28}$ The changes to New Zealand's industrial relations system that followed displayed a shift from a focus in the law on equity and fairness to a focus on freeing the labour market to make it more responsive to the conditions of the global economy and market. ${ }^{29}$ Accordingly, deregulations of the tight controls on labour were the result.

Compulsory arbitration was abolished in 1984 with the Industrial Relations Amendment Act, and was replaced with voluntary arbitration; this system attempted to encourage private sector unions and employers to settle their disputes without the involvement of a third party. ${ }^{30}$ The Labour Relations Act of 1987 required registered unions to have at least 1,000 employee members in order to be covered by an arbitral award. ${ }^{31}$ The 1987 Act also attempted to reform employment relations by encouraging

\footnotetext{
${ }^{24}$ Dannin, above $\mathrm{n} 1$, at 14 .

${ }^{25}$ Ibid, at 15 .

${ }^{26}$ Ibid.

27 Ibid.

${ }^{28}$ Ellen Dannin Working Free: The Origins and Impact of New Zealand's Employment Contracts Act (Auckland University Press, Auckland, 1997) at 26.

${ }^{29}$ Rasmussen, above n 12, 68.

30 Ibid, at 69.

31 Ibid.
} 
enterprise and industry bargaining. ${ }^{32}$ These changes, however, still retained the protections of the national award system. ${ }^{33}$

The economy continued to weaken by the time the National Party won the election in 1990. By 1990, 239,700 people were without jobs out of a working-age population of 2,219,500. ${ }^{34}$ In late 1990 , unemployment increased to 15 - 20 per cent. ${ }^{35}$ The poor economic state of the country became the fuel behind the fire for the National Government's opportunity to embark upon radical labour reform. ${ }^{36}$

It was argued that the strict controls on the labour market from the awards system contributed to New Zealand's economic turmoil. ${ }^{37}$ Accordingly, a Labour Relations Amendment Act was passed in 1990, which permitted employers to opt out of award coverage in favour of negotiating a separate agreement. ${ }^{38}$ This law, however, was short lived, and was quickly abandoned before its impacts on the labour market were felt. By 1991, the poor economy and high unemployment rates set the stage for radical change. ${ }^{39}$

\section{The Employment Contracts Act of 1991 and Its Legacy}

The National Government implemented the Employment Contracts Act (ECA) in 1991. The ECA sought to promote an "efficient labour market" by implementing a pure contracts based approach to employment relations. ${ }^{40}$ The underlying principles of the ECA included a focus on individualism, the freedom of choice, the freedom of contract, and market flexibility - ideas all coming from the neoclassical theories of economics of the University of Chicago school of law and economics. ${ }^{41}$ Compulsory unionism and the

\footnotetext{
32 Ibid.

${ }^{33}$ Gordon Anderson “'The Sky Didn’t Fall In’: An Emerging Consensus on the Shape of New Zealand Labour Law?” (2010) 23 AJLL 94 at 96.

34 Dannin, above $\mathrm{n} 28$, at 88.

35 Ibid.

${ }^{36}$ Ibid.

${ }^{37}$ Ibid, at 39.

${ }^{38}$ Rasmussen, above n 12, at 72.

39 Ibid, at 73.

${ }^{40}$ Employment Contracts Act 1991, Long Title.

${ }^{41}$ Davenport and Brown, above n 7, at 11.
} 
arbitration and national awards system were completely abandoned, dismantling 100 years of New Zealand employment legislative tradition. ${ }^{42}$

The ECA was based on the premise that employees and employers have equal bargaining power; accordingly, terms and conditions of employment were to be individualized and set through agreement between the parties without government intrusion. $^{43}$

Under the ECA, New Zealand's system was no longer based on the assumption that the state should play a part in evening out the imbalance of power. The law sought to grant workers the individual choice to join a union or negotiate their employment terms and conditions directly with their own employer, without the encouragement of doing so collectively. ${ }^{44}$ To further emphasize a move away from promoting collective bargaining, the ECA did not even mention the word 'union' in its terms. ${ }^{45}$

The ECA removed essentially all protections for collective bargaining. Unions could only be recognized as agents if the employee specifically requested such representation. However, employers were not required to recognize or bargain with a union, regardless of how large the union's membership rates were at a worksite. ${ }^{46}$ Additionally, there were no provisions for the registration of unions, no arrangements for the recognition of the role of unions in the negotiation of a contract, nor was there an inclusion of procedures for the settling of disputes over wages and conditions. ${ }^{47}$

Ellen Dannin, an American employment law specialist, came to New Zealand in the 1990s at the height of the ECA to research the effects of legal reform on unions and collectivisation. By drastically reforming its industrial relations system at that time, Dannin saw New Zealand as a self-imposed “experiment”, providing insight to the rest of the world of the impact of the law on collective bargaining. ${ }^{48}$ In her extensive work on

\footnotetext{
${ }^{42}$ Anderson, above n 9, at 49.

43 Employment Contracts Act 1991.

${ }^{44}$ Anderson, above n 9, at 50.

45 Employment Contracts Act, 1991.

${ }^{46}$ Anderson, above $\mathrm{n} 9$, at 49.

47 Employment Contracts Act 1991.

${ }^{48}$ Dannin, above $\mathrm{n} 1$, at 6.
} 
the impacts of the ECA on unions and collective bargaining, Dannin criticised the law as not fully taking into account the "significant differences between employees and employers" by assuming both have equal power at the bargaining table, and for ignoring the uphill battle workers face in collectivising without legal protections. ${ }^{49}$

Dannin's research comprehensively revealed the impacts of the ECA legal reform on the state of unionisation in New Zealand. She referred to Pat Walsh, one of New Zealand's foremost industrial relations specialists at the time, to describe the impacts of the ECA:

The broad parameters of life under the Employment Contracts Act were already apparent in its first six months of operation - a substantial, perhaps irreversible fall in trade union membership and collective bargaining coverage, the continued erosion of employment conditions and employment security, a growing sense of employer strength and (in some quarters) militancy, and a more confliction and antagonistic approach to industrial relations rather than the idealized picture of harmonious co-operation sketched by its advocates. ${ }^{50}$

Within the ECA's first year, unions lost approximately 50 per cent of their members. Over the next few years, many unions simply disappeared. ${ }^{51}$ After the enactment of the ECA, unions that were dependent on compulsory membership collapsed. ${ }^{52}$ Unions struggled to recruit new members and retain current members. Over the nine years that the ECA was in place, union density fell from 42 per cent to 17 per cent, with collective bargaining coverage amounting to 25 per cent of the New Zealand workforce. ${ }^{53}$

In attempting to enforce a system based on principles of unrestrained market forces and freedom of contract, Dannin described the ECA as being "as close to the "law of the jungle" as employment law could be. ${ }^{54}$ The focus on individual employment contracts, she stated, "signalled a change from the collective to the individual and from

\footnotetext{
${ }^{49}$ Dannin, above n 28, at 268.

${ }^{50}$ Ibid, at 120; see Pat Walsh "The Employment Contracts Act” in Jonathan Boston \& Paul Dalziel (eds) The Decent Society? Essays in Response to National Economic and Social Policies (Oxford University Press, Auckland, 1992) 59, at 74.

${ }^{51}$ Dannin, above $\mathrm{n} 1$, at 6

${ }^{52}$ Anderson, above n 30, at 98 .

${ }^{53}$ Anderson, above n 8, at 50.

${ }^{54}$ Dannin, above $n 1$, at 6.
} 
communal or humanistic values to economic and quantitative values.”55 Dannin claimed that other countries could not ignore the "importance or relevance of the developments" occurring in New Zealand with the enactment of the ECA to understand how removing all protections for collectivisation devastatingly impacts unionisation. ${ }^{56}$

The regime of the ECA demonstrated the ultimate meaninglessness of full freedom in collective bargaining. While that system gave a worker the right to choose any representative form, that choice was hollow since the employer had no corresponding need to recognize that choice in a worthwhile way....If a society believes that collective bargaining performs a valuable role, then it must support that choice. ${ }^{57}$

Dannin emphasised that the ECA's hands-off approach to employment relations permitted employers to make the ultimate decision of whether an employee could unionise. Without any legal protections to require an employer to recognise the union, employers could control the collective bargaining process, deciding to deny workers the ability to unionise if they chose so. ${ }^{58}$

To move forward, Dannin argued that New Zealand employment law should at least require employers to be bound to a duty to bargain in good faith or some sort of equivalent to enable or force the conclusion of a collective agreement. ${ }^{59}$ Although arbitration could be a beneficial process to reach a settlement, Dannin saw unions' previous dependency and reliance on arbitration before the ECA as disastrous. ${ }^{60}$ In providing too much union protection, the IC\&A Act allowed and almost encouraged unions to be unresponsive to their membership. ${ }^{61}$ She stressed that regardless of the law, unions need to depend on organising activism to guarantee their existence. ${ }^{62}$ Dannin argued that the IC\&A Act and the ECA equally contributed to New Zealand unions' failure, and to progress away from this, future legislation should learn from the implications these two laws had on collective bargaining.

\footnotetext{
${ }^{55}$ Ibid, at 120 .

${ }^{56}$ Ibid, at 8 .

${ }^{57}$ Ibid, at 153.

${ }^{58}$ Ibid.

${ }^{59}$ Ibid, at 154 .

${ }^{60}$ Ibid.

${ }^{61} \mathrm{Ibid}$, at 158 .

${ }^{62} \mathrm{Ibid}$, at 155.
} 
By the time of the MMP election in 1996, the unpopularity of the ECA was widespread. ${ }^{63}$ After a complaint had been issued to the International Labour Organization (ILO) by the NZCTU in 1993 that the ECA violated ILO Conventions 87 and 98 on freedom of association and collective bargaining, the ILO's findings were that the ECA was “difficult to reconcile” with internationally recognised rights and made recommendations for reform.

The Labour Party outspokenly recognised the ECA's failure to address the unequal bargaining power between employers and employees, and pledged to introduce a legislative requirement to bargain in good faith to remedy this imbalance. ${ }^{64}$ Once the Labour party regained power, the result was the Employment Relations Act (ERA) in 2000.

\section{The Current Legislation: The Employment Relations Act of 2000}

The ERA has attempted to become a middle ground between the ECA and the old arbitration awards system of the IC\&A Act in order to strike a balance between employees and employers. In stark contrast to the ECA, the ERA 2000 recognised in its language the "inherent inequality of bargaining power” between workers and employers. ${ }^{65}$ The Employment Relations Amendment Act 2004 then removed the word "bargaining" from the object of the Act in order to recognise that "the inherent inequality of power in employment relationships requires a broader focus than on bargaining power alone."66 The ERA clearly sought to move away from the ECA's premise that the parties to an employment relationship possessed equal strength, and one of the ways it attempted to do so was to remedy the inequality by imposing a statutory duty for employers and unions to conduct their behaviour with one another in good faith.

Unlike the ECA, the focus of the ERA is on employment relationships, as opposed to individual contractual relationships, with the duty of good faith as the focus to

\footnotetext{
${ }^{63}$ Davenport and Brown, above n 7 , at 17.

64 Ibid.

${ }^{65}$ Employment Relations Act 2000, s 3.

${ }^{66}$ Employment Relations Amendment Act (No 2) 2004 Explanatory Note, p 3.
} 
harbour these relationships. Yet, the ERA still retained workers' right to individual choice. ${ }^{67}$ The Labour government’s Explanatory Note of the Employment Relations Bill provided that the policy behind the ERA was:

...based on the understanding that employment is a human relationship involving issues of mutual trust, confidence and fair dealing, and is not simply a contractual, economic exchange. This basis requires specific recognition in any regulation of the relationship - something not satisfactorily achieved by general contract law.

The overarching objective of the [Act] is therefore to build productive employment relationships through the promotion of mutual trust and confidence in all aspects of the employment environment... ${ }^{68}$

The ERA then, as law, sets forth the objectives for achieving this policy goal in section 3 of the Act:

(a) to build productive employment relationships through the promotion of mutual trust and confidence in all aspects of the employment environment and of the employment relationship -

(i) by recognising that employment relationships must be build on good faith behaviour; and

(ii) by acknowledging and addressing the inherent inequality of bargaining power in employment relationships; and

(iii) by promoting collective bargaining; and

(iv) by protecting the integrity of individual choice, and

(v) by promoting mediation as the primary problem-solving mechanism; and

(vi) by reducing the need for judicial intervention; and (b) to promote observance in New Zealand of the principles underlying International Labour Organisation Convention 87 on Freedom of Association, and Convention 98 on the Right to Organise and Bargain Collectively. ${ }^{69}$

The ERA expects the parties to an employment relationship to be "active and constructive in establishing and maintaining a productive employment relationship."70 To do this, the parties are required to be responsive and communicative, open and honest without misleading one another. ${ }^{71}$

\footnotetext{
${ }^{67}$ Employment Relations Act 2000, s 3.

68 Rudman, above n 5, at 89; see Employment Relations Act 2000, explanatory note.

${ }^{69}$ Employment Relations Act 2000, s 3.

${ }^{70}$ Code of Good Faith in Collective Bargaining, s 1.3.

71 Ibid.
} 
In 2004, the Labour government attempted to strengthen the protections for collective bargaining by passing the Amendment Act. The Amendment Act sought to increase penalties for a breach of good faith, limit employers' ability to undermine the collective, and strengthen provisions to encourage the conclusion of collective agreement. In November of 2008, the National Government regained control. By the end of 2010, the National government made several amendments to the ERA that will go into effect in April 2011. These changes merely seek to "clarify" any issues surrounding communications made by employers to employees during bargaining, but retain good faith as the centrepiece of the legislation. Both of these legislative amendments are discussed in more detail below.

Instead of relying solely on case law to develop and further define what the duty of good faith entails over time, section 35 of the ERA gave the Minister of Labour the authority to periodically approve codes of good faith. The Codes of Good Faith outlines what the duty of good faith entails and provides guidance on what constitutes good faith behaviour in collective bargaining. Similarly, the Minister of Labour is also authorized to approve codes of employment practice, providing further direction on the topic. While these codes are not exhaustive and are no substitution for the ERA, they are to be followed in determining whether the parties have acted in good faith in compliance with the ERA. ${ }^{72}$

\section{Conclusion regarding New Zealand's Employment Law History}

As industrial relations specialists Barry Foster ${ }^{73}$ and Ian McAndrew ${ }^{74}$ have described it,

New Zealand has a colourful industrial relations history, having ventured through a full range of industrial relations systems over just the past 30 years. Each of

\footnotetext{
${ }^{72}$ Code of Good Faith in Collective Bargaining, s 1 (Introduction).

${ }^{73}$ Barry Foster is a Lecturer in the Department of Human Resources Management at Massey University.

${ }^{74}$ Ian McAndrew is a Senior Lecturer in Labour Relations at the University of Otago and Co-Editor of the New Zealand Journal of Industrial Relations.
} 
them has given a different shape and character to collective bargaining in this country. ${ }^{75}$

The progression embarked upon by New Zealand's industrial relations system had had many impacts collective bargaining and the shape of unionisation today.

Today, the promotion of good faith behaviours and collective bargaining in order to build productive employment relationships is the centrepiece of New Zealand's industrial relations legislative framework. However, the impact of such requirements is an area that is yet to be fully explored.

This thesis will ultimately discuss the impacts of the ERA's good faith reforms on the parties to collective bargaining. However, now that a foundation describing the history of New Zealand's employment laws has been established, this paper will next provide a brief description of the current law. This section outlines what the duty of good faith requires of employers' and unions' behaviour in collective bargaining under the ERA.

\section{B. The ERA's Duty of Good Faith in Collective Bargaining}

\section{Introduction}

The ERA's duty of good faith applies to all aspects of the employment relationship, including collective bargaining. Good faith in collective bargaining is the only aspect that will be investigated for purposes of this study. Accordingly, the following are the applicable provisions in the ERA with regards to collective bargaining under the duty of good faith.

This section explains what is required of unions and employers in collective bargaining in terms of good faith. Because this paper ultimately presents how unions'

\footnotetext{
${ }^{75}$ Barry Foster and Ian McAndrew "Growth and Innovation Through Good Faith Collective Bargaining: An Introduction to the Conference Collection" (2003) 28(2) New Zealand Journal of Industrial Relations 118 at 118.
} 
and employers' behave under the good faith provisions, a fundamental knowledge of what the law requires is necessary.

\section{Basic Good Faith Bargaining Requirements}

While the ERA does not explicitly define what good faith is, the law does set forth both mandatory good faith requirements and prohibitions with regards to collective bargaining. Bargaining is defined in section 5 of the ERA as

(a) ....all the interactions between the parties to the bargaining that relate to the bargaining; and

(b) includes -

(i) negotiations that relate to the bargaining; and

(ii) communications or correspondence (between or on behalf of the parties before, during, or after negotiations) that relate to the bargaining

Accordingly, the good faith requirements as set forth in the ERA with regards to bargaining are not limited to just negotiations; rather, the duty applies to the interactions between the parties of bargaining relating to the bargaining.

Section 4(1) of the ERA requires the parties to an employment relationship, including unions and employers to, "deal with each other in good faith" and not do anything that does or is likely to "mislead or deceive each other."

Section 32 sets forth the requirements for the parties to comply with section 4 with regards to treating one another in good faith. It states that unions and employers are required at a minimum to

- $\quad$ use their best endeavours to reach an agreement setting forth a process for conducting bargaining in an efficient and effective way;

- meet with one another from time to time for purposes of bargaining;

- $\quad$ consider and respond to the proposals made by each other;

- $\quad$ recognize the authority and role of the party's bargaining representative; 
- $\quad$ not bargain directly or indirectly with the party in any form other than their chosen bargaining representative;

- $\quad$ not do anything that undermines or is likely to undermine the bargaining process or the authority of bargaining representative; and

- $\quad$ provide requested information that is reasonably necessary to support or substantiate claims or responses.

\section{Union Requirements}

Employees who choose to engage in collective bargaining or be covered under a collective agreement must belong to a union under the Employment Relations Act. Under sections 13 and 14 of the ERA, a union must:

- Be comprised of at least 15 members

- Register and maintain that registration under the Incorporated Societies Act of 1908

- One of its objects must be the promotion of its members' collective interests

- Not have rules that are unreasonable, unfairly discriminatory, unfairly prejudicial, undemocratic or contrary to existing law

- Be independent from and not within arm's length of an employer

- Register with the Registrar of Unions under the ERA and maintain that registration

The Department of Labour's Registrar of Unions must register any applicant union that meets the criteria set forth in section 15. Registration may be cancelled if the union requests so or if the union no longer meets the criteria. ${ }^{76}$ Employees may create their own union or join an existing union as long as said union complies with the requirements listed above.

\section{Initiating the Bargaining Process}

Section 42 of the ERA states that to initiate bargaining, a party must follow these requirements:

\footnotetext{
${ }^{76}$ Employment Relations Act 2000, s 17.
} 
(1) A union or employer initiates bargaining for a collective agreement by giving to the intended party or parties to the agreement a notice that complies with subsection (2).

(2) A notice complies with this subsection if -

(a) it is in writing and signed by the union or the employer giving the notice or its duly authorized representative; and

(b) it identifies each of the intended parties to the agreement; and

(c) it identifies the intended coverage of the collective agreement.

When providing this bargaining initiation notice, the party is required under section 42(2)(c) to also "identify the intended coverage of the collective agreement." Section 5 of the ERA defines a coverage clause in an initiating notice as a

"...provision in the notice specifying the work that the agreement is intended to cover, whether by reference to the work or type of work or employees or types of employees.

In other words, the initiating party must specify either the work or the employees, or both, that the collective agreement will cover. This can be done by naming the employees to be covered by the bargaining, listing the type of work that will be covered, or listing the type of work done by the named employees. ${ }^{77}$ The Employment Relations Authority later held that the parties to bargaining may agree on coverage of a different scope than what has been set forth in a coverage clause. ${ }^{78}$

Once the union gives an employer an initiating bargaining notice or an employer has issued an initiating notice, an employer is required under Section 43 of the ERA to advise all employees, both union and non union members, of the work that would be covered by the proposed coverage clause of the intended parties to the bargaining or the existing parties to bargaining and its coverage. This must be done no later than 10 days after the initiating notice has been issued. ${ }^{79}$

\footnotetext{
77 Employment Relations Act 2000, s 5.

78 Davenport and Brown, above n 7, at 37; see also NUPE v NZ Customs Service [2001] CA 5 (ERA).

${ }^{79}$ Employment Relations Act 2000, s 43.
} 


\section{Bargaining Process Agreements (BPA)}

Section 32 of the ERA requires that, once bargaining has been initiated, the

...union and the employer must use their best endeavours to enter into an arrangement, as soon as possible after initiation of bargaining, that sets out a process for conducting the bargaining in an effective and efficient manner.

The parties' behaviour will be bound to the process agreed to in this document. ${ }^{80}$

Although the terms to this requirement were not expressly defined by the ERA, the Employment Relations Authority has interpreted how the requirement should be applied. NZ Amalgamated Engineering Printing and Manufacturing Union $v$ Independent Newspapers Ltd held that "efficiency" means "productive, with minimum waste or effort." ${ }^{81}$ In the same case, the Authority also defined "best endeavours" as an effort that does not require the employer to conduct its business to the union's benefit in such a way that customers are driven to its competitors, nor does it mean that "the bounds of reason must be over-scored with regards to the cost of the service"; rather, "best endeavours" means that "no stone" is left "unturned." 82

The Code of Good Faith enumerates a list of useful topics that could be included in a bargaining process agreement (BPA) such as, just to name a few, the manner in which proposals are made and responded to, the appointment of a mediator if problems in bargaining arise, the frequency of meetings, etc. ${ }^{83}$

The duty of good faith applies with regards to BPAs, prohibiting parties from engaging in tactics to delay or undermine the bargaining process. ${ }^{84}$ However, if a bargaining process agreement cannot be reached, the parties are permitted to continue onto bargaining. ${ }^{85}$

\footnotetext{
${ }^{80}$ Code of Good Faith in Collective Bargaining, s 2.3

${ }^{81}$ Davenport and Brown, above n 7, at 45; see NZ Amalgamated Engineering Printing and Manufacturing Union v Independent Newspapers Ltd [2001] 6 NZELC 96 at 360.

${ }^{82}$ Ibid, at 46.

${ }^{83}$ Code of Good Faith in Collective Bargaining, s 2.2.

${ }^{84}$ Employment Relations Act 2000, s 5(b)(ii).

${ }^{85}$ Code of Good Faith in Collective Bargaining, s 2.1.
} 


\section{Meeting and Presenting Claims Requirements}

Section 32(b) of the ERA requires unions and employers to "meet each other, from time to time, for the purposes of the bargaining." These meetings are for open for the parties to "explain, discuss, and consider proposals" and each other's position in bargaining. ${ }^{86}$

Once bargaining has been initiated, both sides are expected to honestly and consistently communicate their desired pay rate, terms and conditions, benefits and other conditions they are seeking in negotiations, and reasons as to why these claims are being sought. ${ }^{87}$ In order to act in good faith, the parties should engage in a genuine dialogue with one another about their needs in the situation, their restrictions, and their concerns. ${ }^{88}$

The Employment Relations Authority clarified in National Distribution Union $v$ Sawmill Services Ltd and Ors that it is reasonable for a party to request a meeting be postponed if there are several claims or documents to consider. ${ }^{89}$

Section 32(2) of the ERA states that the duty of good faith "does not require a union and an employer to continue to meet each other about proposals that have been considered and responded to.”

In New Zealand Licensed Rest Homes Association Incorporated and Others $v$ Midland Regional Health Authority, the Employment Relations Authority stated that the parties to bargaining are required to make "open minded and respectable efforts to reach a fair and reasonable accommodation." ${ }^{90}$

Employers and unions are permitted to engage in hard bargaining, provided "they are amenable to listening to reasons why they should change their preference." The Employment Relations Authority has stated, "good faith requires no more than that in

\footnotetext{
${ }^{86}$ Code of Good Faith in Collective Bargaining, s 3.11.

${ }^{87}$ Employment Relations Act 2000, s 32.

${ }^{88}$ Employment Relations Act 2000, s 32(3).

89 Davenport and Brown, above n 7, at 60.

${ }^{90}$ Ibid, at 65 .
} 
respect of keeping an open mind." ${ }^{91}$ Along these lines, parties are not permitted to adopt a "take it or leave it" approach to bargaining because it implies that the party is not engaging in bargaining meaningfully.

The Amendment Act requires the parties to conclude a collective agreement unless there are reasonable grounds not to reach an agreement. ${ }^{92}$ Accordingly, surface bargaining in which an employer is simply going through the motions of bargaining without any intent to conclude an agreement is a breach of good faith. Additionally, providing reason behind a claim at bargaining furthers the Act's purpose of promoting honest relationships. ${ }^{93}$

Section 32(1) of the ERA requires that the employer and the union "consider and respond to proposals made by each other" once bargaining has commenced and the parties are given the opportunity to put their claims on the table. The duty of good faith requires the parties to justify their respective claims, a requirement in line with the Act's objective for honest and open communication.

\section{Collective Agreement Requirements}

The parties to bargaining are required to reach an agreement unless there are reasonable grounds not to. ${ }^{94}$ The Act expressly states that objecting to bargaining for a collective agreement, opposing to being a party of bargaining, and disagreement over a collective bargaining fee clause are not reasonable grounds. ${ }^{95}$ Additionally, section 54(2) and 3(b) provides that the parties decide what they agree upon provided such terms are lawful and consistent with the ERA. To be consistent with the ERA, such an agreement must:

- be in writing and signed by the union and employer parties bound to it ${ }^{96}$

- include an expiry date that must be three years or less; and ${ }^{97}$

\footnotetext{
${ }^{91}$ Ibid, at 69; see also NZ Amalgamated Engineering Printing and Manufacturing Union v Independent Newspapers Ltd [2001] 6 NZELC 96 at 360.

${ }^{92}$ Employment Relations Amendment Act 2004, s 33.

${ }^{93}$ See the Object of the Employment Relations Act 2000, s 3.

${ }^{94}$ Employment Relations Amendment Act 2004, s 33.

${ }^{95}$ Ibid.

${ }^{96}$ Employment Relations Act 2000, s 54(1)
} 
- contain a coverage clause specifying the work the collective agreement covers $^{98}$

- include a clause setting forth the rights and responsibilities of the employees and employers in the event that the work covered by the agreement is subcontracted out or part or all of the employer's business is sold or transferred; ${ }^{99}$

- include a plain language explanation of the dispute resolution services available to the parties of bargaining under the ERA should problems arise; and

- a variation clause ${ }^{100}$

The parties may choose to limit their agreement to being between one employer and one union, or may decide to reach a multi-party agreement. If an agreement is between one union and multiple employers or one employer and multiple unions, the ERA requires that other procedures and obligations be followed. ${ }^{101}$

Section 55 of the ERA provides that every collective agreement will be treated as if it contains a clause requiring the employer, with the employee's consent, to deduct union dues from the employee's earning to be paid to the union. The parties to the collective agreement may agree to omit this provision or alter its terms.

Employers are required under section 26 to allow union members to attend at least two meetings a year for up to two hours, and are to be given ordinary pay for this time. Unions are required to give employers at least 14 days notice of a union meeting and take measures to ensure the employer's business continues during this time period. ${ }^{102}$

\section{Good Faith Bargaining Prohibitions}

Good faith is stressed in the ERA to encourage development of mutual trust in employment relations as well as providing protection against unfair bargaining. Accordingly, as mentioned earlier, the ERA prohibits bargaining parties from:

\footnotetext{
${ }^{97}$ Employment Relations Act 2000, ss 43(3)(a)(v) and 52(3).

${ }^{98}$ Employment Relations Act 2000, s 54(3).

${ }^{99}$ Ibid.

${ }^{100}$ Ibid.

${ }^{101}$ See Employment Relations Act 2000 s 45; s 56A(3) for an outline of requirements that must be followed for a multi-employer collective agreement, or for another union to join a collective agreement.

${ }^{102}$ Employment Relations Act 2000, s 26.
} 
- doing anything that directly or indirectly misleads or deceives or is likely to mislead or deceive one another; ${ }^{103}$

- acting in a manner that is inconsistent with recognizing the role and authority of a bargaining representative; ${ }^{104}$

- bargaining with represented parties, unless the representative agrees otherwise; ${ }^{105}$ and

- undermining or doing anything that is likely to undermine the bargaining or bargaining representative ${ }^{106}$

The prohibition on engaging in misleading or deceiving behaviour or behaviour that could potentially mislead or deceive is not defined in the ERA, however it is likely that the courts will interpret the prohibition in accordance with the goals of the Act and other jurisprudence with the same standard. Additionally, the other prohibitions could be interpreted quite broadly.

It should be noted that Sections 32(1) and (5) of the ERA make it clear that these prohibitions in sections 4 and 32 of the Act are not exhaustive. There is certainly more behaviour which would likely be seen as undermining the bargaining in breach of good faith, discussed below.

\section{Information Disclosures during Bargaining}

(a) Requested Information

Section 32(1)(e) of the ERA requires employers and unions engaged in bargaining to provide one another with information, upon request, that is "reasonable necessary to support to substantiate claims or responses to claims made for the purposes of bargaining." Remembering the definition of bargaining in section 5 and the good faith requirements under 32, it is clear that employers and unions are permitted to request information at any time as necessary after an initiating notice has been made.

Being able to request information from the other side in bargaining "to support or substantiate claims or responses to claims” promotes honest, open, communicative

\footnotetext{
${ }^{103}$ Employment Relations Act 2000, s 4.

${ }^{104}$ Employment Relations Act 2000, s 32 (1)(d)(i).

${ }^{105}$ Employment Relations Act 2000, s 32(1)(d)(ii).

${ }^{106}$ Employment Relations Act 2000, s 32(1)(d)(iii).
} 
relationships based on mutual respect and trust. In other words, informed bargaining promotes good faith in furtherance of the ERA's goals. When parties have the information to fully understand their bargaining counterpart's position, they are better able to make informed decisions that are fair. Providing accurate information prevents misleading or deceiving behaviour. The requirement facilitates rational discussions during bargaining instead of misunderstandings that could potentially lead to conflict. Furthermore, requiring a party to provide information substantiating their claim helps even out the bargaining power discrepancy existing between parties to an employment relationship.

Section 34(2) of the ERA provides the following procedures for making an information request:

(3) A request by a union or an employer to the other for information must -

(a) be in writing; and

(b) specify the nature of the information requested in sufficient detail to enable the information to be identified; and

(c) specify the claim or the response to a claim in respect of which information to support or substantiate the claim or the response is requested; and

(d) specify a reasonable time within which the information is to be provided.

Again, these terms are not defined in the ERA. However, it follows that the parties may begin making requests as soon as an initiating bargaining notice has been issued, and these requests must be made in good faith by both employers and unions.

Section 34(3) of the Act then goes on to provide that the information being requested must be provided either directly to the requesting party or to an independent reviewer if the party providing the information reasonably considers that it should be treated as confidential. If a party decides to use an independent reviewer, section 34(4) requires that such person will need to be appointed mutually by the union and the employer. If the independent reviewer determines that the information should be treated as confidential, the ERA provides several requirements as to how the information should 
then be handled. ${ }^{107}$ "Confidential information” is not defined under the ERA; however, other case law on the topic suggest that the term means trade secrets. ${ }^{108}$

Section 34(7) of the ERA restricts the usage of requested information. Information

- $\quad$ must be used only for the purposes of the bargaining concerned;

- must be treated as confidential by the persons conducting the bargaining; and

- must not be disclosed by those persons to anyone else, including employees or other employers who would be bound by the collective agreement being bargained for.

The duty of good faith will also be applied in this situation to avoid using the information in such a way that it undermines bargaining or the authority of the bargaining representatives.

(b) Information Not Requested

In order to engage in good faith behaviour that does not mislead or deceive, a party should not assume that its bargaining counterpart is informed or has access to all information that, without it, could lead to misunderstandings and conflicts during bargaining. In some circumstances, silence at the bargaining table can be misleading conduct in breach of the duty of good faith. ${ }^{109}$

\section{Undermining the Bargaining Process}

Employers, unions, and employees are all prohibited from doing anything that is "likely" to undermine the bargaining authority of a bargaining representative. The ERA makes it clear that the prohibitions it enumerates in sections 4 and 32 of the Act are not exhaustive, and much is left to be decided through case law or common practice. However, these are just a few examples in which the parties could be seen as undermining the bargaining in breach of the duty of good faith.

\footnotetext{
107 See Employment Relations Act 2000, s 34(6).

108 Davenport and Brown, above n 7, at 217.

${ }^{109}$ Employment Relations Amendment Act 2004, s 4(1A)
} 


\section{(a) Communication with Employees During Negotiations}

Communications amounting to direct or indirect bargaining must be directed to the bargaining representative only. ${ }^{110}$ The Code of Good Faith also reiterates that:

The parties must recognise the role and authority of any person chosen by each to be its representative or advocate. ${ }^{111}$

Accordingly, Section 32(1)(d)(ii) prohibits the parties to bargain with represented constituents. Notably, Section 5 defines bargaining for purposes of a collective agreement quite broadly to include "all the interactions between the parties to the bargaining that relate to the bargaining..." including "negotiations", “communications", and "correspondence (between or on behalf of the parties before, during or after negotiations)" that "relate to bargaining". Accordingly, the original form of section 32(1)(d)(ii) restricted communications or correspondence relating to the bargaining.

In Christchurch City Council v Southern Local Government Officers Union, the Court of Appeals clarified that section 32 of the ERA does not completely ban communications relating to bargaining by a party to the bargaining to a represented person or persons. Rather, bargaining parties are permitted to communicate statements of fact or opinions that are reasonably held about the employer's business or the union's business so long as the communication does not undermine the bargaining or the authority of the representative in breach of section 32(1)(d). ${ }^{112}$

This case was considered when the National Government decided to again amend the ERA in 2010 to clarify that employers are permitted to communicate with their employees during bargaining. Section 32(6), effective 1 April 2011, provides:

To avoid doubt, this section does not prevent an employer from communicating with the employer's employees during collective bargaining (including without limitation, the employer's proposals for the collective agreement) as long as the communication is consistent with subsection $(1)(d)$ of this section and the duty of good faith in section 4 .

\footnotetext{
${ }^{110}$ Employment Relations Act 2000, s 32.

${ }^{111}$ Code of Good Faith in Collective Bargaining, s 3.7.

112 Christchurch City Council v Southern Local Government Officers Union [2007] 2 NZLR 614 at 623.
} 
This section will be interpreted with the current law holding that an employer is allowed to communicate with its employees belonging to a union about its business, but not about the bargaining per say. ${ }^{113}$ The law is also clear that direct communications are permitted as long as they are not:

- directly or indirectly misleading or deceptive or likely to be so to the receiving party of the communication ${ }^{114}$

- $\quad$ amounting to direct or indirect bargaining ${ }^{115}$

- undermining the bargaining process itself ${ }^{116}$

- undermining the authority of the bargaining representatives ${ }^{117}$

Communications made by an employer to employees during bargaining is an area that has resulted in litigation and much dispute between parties. The extent to which employers may communicate directly to its staff during negotiation about matters being discussed in those negotiations is somewhat unclear under the law, and as revealed in the interviews conducted for this study, a source of contention. The effectiveness of these new provisions in clarifying any problems surrounding communications made during bargaining shall be seen later this year.

(b) Sending uninformed representatives to the bargaining table

Because a bargaining representative needs knowledge of the bargaining issues at hand, the bargaining process, the workers involved and the type of work in that industry, a representative without this knowledge will be unable to engage in meaningful bargaining and will waste time. Additionally, sending a representative without authority to make a decision to the bargaining table also frustrates the bargaining process.

\footnotetext{
113 Employment Relations Act 2000, s 4(3).

114 Employment Relations Amendment Act 2004, s 4(1)(b).

115 Employment Relations Amendment Act 2004, s 32(1)(d)(ii).

${ }^{116}$ Employment Relations Amendment Act 2004, s 32(1)(d)(iii).

117 Ibid.
} 
Accordingly, sending such a representative into bargaining may be considered to be inconsistent good faith. ${ }^{118}$

(c) Dragging out the bargaining process or unnecessarily rushing through the bargaining process

Again, a party who is not engaging in meaningful bargaining by rushing through the process or unreasonably making the process much longer in order to frustrate the purpose is likely to be seen as acting in bad faith. ${ }^{119}$

(d) Inaccurately informing constituents or failing to inform constituents of the progress and offers being made during bargaining

In order for the parties to fully understand the other side's position so that bargaining can move forward and an agreement can be reached, bargaining representatives need to accurately inform their constituents of the progress and offers being put on the table. Bargaining representatives are expected to advance the interests of their constituents at the bargaining table, and part of that role includes reporting back accurately and comprehensively to avoid any misleading or deceptive behaviour. ${ }^{120}$ If the parties are bargaining in good faith, then all communications are open, honest, and informed; accordingly, any claims put on the table will not come as a complete surprise because the parties should know the basis of the other side's position. ${ }^{121}$

(e) Attempts to Induce Employees

Section 4(6) provides that it is a breach of good faith for an employer to advise or do anything with the intention of inducing an employee not to be involved in bargaining for a collective agreement or not be covered by a collective agreement.

\footnotetext{
${ }^{118}$ Davenport and Brown, above n 7, at 117.

${ }^{119}$ Davenport and Brown, above n 7, at 119.

${ }^{120}$ Employment Relations Act 2000, s 4(2); see also Code of Good Faith in Collective Bargaining, s 1.3.

${ }^{121}$ Davenport and Brown, above n 7, at 121.
} 
(f) Pass-on the collective terms and conditions of employment to non-union members of the staff

The Employment Relations Act as originally enacted in 2000 permits employers to "pass-on" the terms and conditions negotiated and gained through collective bargaining for union members to non-union members. Specifically, section 59B provides that pass-on of a term or condition agreed to in collective bargaining will not, in and of itself, constitute a breach of good faith. As a result, employers may give non-union members of its staff the same benefits as provided in the collective agreement without requiring these non-union members to pay union dues, with some exceptions.

The ERA has perpetuated pass-on by requiring employers to give the terms equivalent to those in a collective agreement to new employees whose job falls under the collective agreement's coverage clause. It is likely that this provision was added in the ERA contrary to the Labour government's intentions. The new employee has the individual choice to join the union, but also might even have incentive not to since, from their start date, they are benefiting from what the union has achieved for its members without having to pay union dues. At the end of the first 30 days of employment, an employee may elect to join the union or not, and also decide whether or not they would like the terms and conditions of their employment to be different than the collective agreement - a choice allowing the employee to still receive the benefits of the collective without joining the union. The incentive for an employee to decide to keep the same terms and conditions as union members without having to pay to become a union member is clear.

The test of whether there has been a breach of the duty of good faith is different depending on if a collective agreement has been reached. Once collective bargaining has concluded, an allegation of pass-on in breach of the good faith provisions brought to the Employment Relations Authority is bound to the standard set forth in sections 59B(1) and (2) of the ERA to determine the outcome. According to Sections 59B(1) and (2) of the ERA, 
(1) It is not a breach of the duty of good faith in section 4 for an employer to agree that a term or condition of employment of an employee who is not bound by a collective agreement should be the same or substantially the same as a term or condition in a collective agreement that binds the employer.

(2) However, it is a breach of the duty of good faith in section 4 for an employer to do so if -

a. the employer does so with the intention of undermining the collective agreement; and

b. the effect of the employer doing so is to undermine the collective agreement.

The standard is lower, however, for a breach of good faith pass-on case brought before the Employment Court while bargaining is in progress. ${ }^{122}$ If bargaining is in progress, the union alleging that the employer breached good faith through pass-on needs to prove one of the elements set forth in section 59B(2), not both.

Thus, the standard today is that an employer can only be found to be in breach of good faith if it can be shown that the employer deliberately sought to undermine the bargaining process or the collective bargaining agreement through pass-on. As a result, employers have the incentive to wait until bargaining has concluded to pass-on because the threshold for then proving a breach of good faith is usually too high for the union to pursue the case.

The courts in New Zealand have not set forth factual scenarios in which a finding of bad faith is necessitated when pass-on has occurred. While it is unnecessary to establish that all the terms and conditions to a collective bargaining agreement have been passed-on to prove a breach of good faith, a breach can be found when just one term or condition have been passed-on, “especially” when it is "an important one such as wage rates.” The circumstances of each case will be considered to determine if a breach of good faith has occurred.

“... amongst a workforce of thousands being paid different hourly rates for a range of different jobs, the identification of one employee or even a small group of employees who might be said to have been offered substantially similar terms and

${ }^{122}$ National Distribution Union Inc. v General Distributors Ltd [2007] 4 NZELR 215, [2007] 4(1) NZELR120 at 122. 
conditions of employment, but ignoring the evidence about other circumstances, could not alone require the conclusion that s59B ERA had been breached....The Court would look for sameness or substantial sameness in substance, not form." 123

To prove a breach of good faith, the pass-on must have the effect of undermining the collective bargaining agreement.

"Section 59B(2) ERA was not concerned with undermining of the union, its ability to bargain, its ability to attract members, or future bargaining for a future CEA. It was concerned solely with the undermining of an extant CEA."124

The Court also recognized that a collective agreement "might only be undermined by passing on in extreme cases," like when a "significant number” of members are persuaded to leave the union by a pass on or a number of new employees leave the CEA after the first 30 days of employment because they can get the same terms and conditions from a pass-on. There is a breach of good faith under the Act in cases like these because "the extent of coverage of the CEA had been substantially diluted" by pass-on. ${ }^{125}$ Additionally, "the sooner any passing on occurred after the CEA came into force, the stronger the inference should be that the employer acted with the intent and effect of undermining the CEA.”126 The Court may also consider whether individual employment agreements are "substantially different in form and content" to the collective agreement. ${ }^{127}$ An employer concealing its intention to pass-on or not consulting with the union before a pass-on can also help prove a breach of good faith. Undermining that is simply incidental without a "known or foreseen consequence of an employer's act done or omission committed for some other purpose, that would be insufficient to establish the necessary intention to undermine. Further, recklessness by an employer as to the consequences of an act or omission that might have the effect of undermining might not be sufficient to establish that employer's intention to undermine."128 However, when an employee receives a term or condition without bargaining, it is presumed to be more

\footnotetext{
123 Ibid, at 124.

124 Ibid, at 125 .

125 Ibid.

126 Ibid, at 127.

127 Ibid.

${ }^{128}$ Ibid, at 126.
} 
likely to have been a pass-on in breach of good faith than if the term had been reached after individual bargaining. ${ }^{129}$

\section{Unilaterally ending collective bargaining}

While there are instances in which bargaining might not result in an agreement, the Employment Relations Authority has held that a party unilaterally determining that bargaining has come to an end is acting in breach of good faith. ${ }^{130}$

\section{Statements to the public, third parties, or media}

Parties to bargaining are permitted to release statements to the third parties, the public, or to media outlets as long as such statements do not undermine the bargaining.

\section{Trade Union Education Leave}

The ERA's inclusion of trade union education leave is also aimed at promoting good faith and collective bargaining by providing an increased understanding of good faith collective bargaining. ${ }^{131}$ Training in good faith can create more productive relationships and encourage bargaining to go more smoothly.

\section{Bargaining Fee Agreements}

In attempt to remedy the problems associated with pass-on, the 2004 Amendment added a provision in the ERA that provides for employers and unions to include a bargaining fee arrangement into their collective agreements. Such an agreement requires non-union members (whose work falls under the coverage clause but chose not to join the union) will be given the same terms and conditions of employment as the union-

\footnotetext{
${ }^{129}$ Ibid.

${ }^{130}$ The New Zealand Public Service Association v Secretary for Justice [2010] 11 NZEMPC WRC 54/09.

${ }^{131}$ Employment Relations Act 2000, s 70.
} 
members, but must pay a bargaining fee to the union that negotiated those terms and conditions. ${ }^{132}$

Bargaining fee arrangements must pass through several hurdles first before they can be included in a collective agreement. First, the employer must agree to include such a clause in the collective agreement. Then, a majority of employees, both union and nonunion members falling under the coverage clause, must agree by secret ballot to the bargaining fee. ${ }^{133}$ The clause must state how much the bargaining fee is, not amounting to more than the union members' dues. ${ }^{134}$ The bargaining fee clause expires when the collective agreement expires. $^{135}$

\section{Mediation}

Under Section 144 of the ERA, the Department of Labour may provide mediation services to support all employment relationships, which include:

- providing general information about employment rights and obligations;

- providing information about the services available to people, unions and employers who have employment relationship problems;

- $\quad$ assisting the smooth conduct of employment relationships in other ways;

- $\quad$ assisting with the prompt and effective resolution of employment relationship problems; and

- $\quad$ assisting with the fixing of new terms and conditions of employment

Included in these services is assistance "to persons to resolve any problem with the fixing of new terms and conditions of employment”, meaning that mediators can help in bargaining for collective agreements. ${ }^{136}$

The Department of Labour provides mediators to parties of collective bargaining for assistance in the process or even facilitation if certain requirements under the ERA are

\footnotetext{
${ }^{132}$ Employment Relations Act 2000, s 69P

${ }^{133}$ Ibid, at s 69Q

${ }^{134}$ Ibid, at ss 69P and 69U

135 Ibid, at s 69V

${ }^{136}$ Ibid, at s 145; see also Rudman, above n 5, at 20.
} 
met. The parties are also permitted to choose a mediator to resolve their disputes that both parties agree upon.

Parties encountering problems in bargaining that seek to have those problems resolved by a mediation may choose to an agreed settlement after the mediation which will then be binding on them. If the parties decide to have a problem resolved by the Department of Labour's mediator, the resolution will be binding on them. ${ }^{137}$

Under section 50C of the ERA, facilitation is available where:

- $\quad$ there has been a breach of good faith by one or more parties, which has been serious and sustained and has undermined the bargaining

- the bargaining has been unduly protracted and extensive efforts (including mediation) have failed to resolve the parties' difficulties

- in the course of bargaining, there has been one or more strikes or lockouts that have been protracted or acrimonious

- a party has proposed a strike or lockout that would, if it occurred, substantially affect the public interest. This includes where the strike or lockout is likely to endanger the life, safety, or health of any persons.

Facilitation merely provides parties with a recommended process to be followed in order to conclude a collective agreement and sometimes will provide recommendations as to terms that should be included in the collective agreement. ${ }^{138}$ While the parties are not required to follow the recommendations made at the conclusion of facilitation, ${ }^{139}$ the Employment Relations Authority is permitted to make such recommendations public. ${ }^{140}$ The parties in facilitation are required to engage in the process with the mediator in good faith. $^{141}$

\footnotetext{
${ }^{137}$ Employment Relations Act 2000, s 150.

138 Employment Relations Act 2000, s 50G.

${ }^{139}$ Employment Relations Act 2000, s 50G.

${ }^{140}$ Employment Relations Act 2000, s 50H.

141 Employment Relations Act 2000, s 50I.
} 
If the breach of good faith was found on grounds that the breach was "sufficiently serious and sustained as to significantly undermine the bargaining” and other reasonable grounds for reaching an agreement have been exhausted, a party may apply to the Employment Relations Authority to "fix" the provisions of the collective agreement. ${ }^{142}$ This remedy is available where the fixing of terms is the only effective remedy for the party being affected by the breach of good faith. ${ }^{143}$ The ERA does not provide a process to be followed in this type of facilitation, providing the Employment Relations Authority with some flexibility in their determination. ${ }^{144}$

\section{Requirement to Conclude a Collective Agreement}

The 2004 Amendment Act created in section 33 an obligation for the parties to bargaining to conclude a collective agreement unless there is a genuine reason based on reasonable grounds not to. The code of good faith has explains that genuine reasons not to conclude an agreement do not include an employer's general opposition or objection to collective bargaining as a principle or a basic opposition to having a collective agreement at their worksite. A genuine reason also may not solely be based on an employer's refusal to have a bargaining fee clause in the collective agreement. ${ }^{145}$

\section{Post Bargaining Requirements}

Once there is a collective agreement in place at a worksite, the employer has several obligations with regards to new employees entering the worksite that will be conducting the type of work covered by the collective agreement.

Section 62 of the ERA requires an employer to tell new employees that a collective agreement exists and that the type of work the employee will be engaging in is covered under that agreement. The employer is also required to provide the union with

\footnotetext{
142 Employment Relations Act 2000, s 50J.

143 Ibid.

144 Gordon Anderson “Transplanting and Growing Good Faith in New Zealand Labour Law” (2006) 19 (1) AJLL 1 at 8.

${ }^{145}$ Employment Relations Amendment Act 2004, s 33.
} 
this new employee's contact information if the employee chooses to join the union, as well as providing the employee with the union's contact details.

Section 63 requires that for the first 30 days of employment, the new employee will be given the same terms and conditions as the collective agreement, as well as any additional terms and conditions negotiated by the employee and employer that are not inconsistent with the collective. After these 30 days if the employee has not chosen to join the union, then the employer and employee may negotiate an individual agreement.

\section{Economic Weapons Available: The Ability to Strike or Lockout}

The use of economic weapons is not considered a breach of good faith under the ERA as long as such action is to further the party's bargaining goals and follows other requirements set forth by the ERA. Section 80(a) of the ERA states that:

The object of this Part is - to recognize that the requirement that a union and an employer must deal with each other in good faith does not preclude certain strikes and lockouts being lawful...

Before determining whether a strike or lockout is lawful, the action must fall under the ERA's definition of strikes and lockouts. Section 82 of the ERA defines a lockout as:

(a) is the act of an employer -

(i) in closing the employer's place of business, or suspending or discontinuing the employer's business or any branch of that business; or

(ii) in discontinuing the employment of any employees; or

(iii) in breaking some or all of the employer's employment agreements; or

(iv) in refusing or failing to engage employees for any work for which the employer usually employs employees; and

(b) is done with a view to compelling employees, or to aid another employer in compelling employees, to -

(i) accept terms of employment; or

(ii) comply with the demands made by the employer. 
Section 81 of the ERA defines a strike as:

(a) is the act of a number of employees who are or have been in the employment of the same employer or of different employers -

(i) in discontinuing that employment, whether wholly or partially, or in reducing the normal performance of it; or

(ii) in refusing or failing after any such discontinuance to resume or return to their employment; or

(iii) in breaking their employment agreements; or

(iv) in refusing or failing to accept engagement for work in which they are usually employed; or

(v) in reducing their normal output or their normal rate of work; and

(b) is due to a combination, agreement, common understanding, or concerted action, whether express or implied, made or entered into by the employees

As the ERA indicates, a strike must involve an act; therefore, words are not sufficient. ${ }^{146}$ Also, one person cannot strike; there needs to be concerted activity. ${ }^{147}$ The person on strike must have an employment agreement with the employer or else the employment cannot be discontinued. ${ }^{148}$ Lastly, the workers on strike do not need to completely withdrawal from their duties; a strike includes any breach of employment, including doing one's work really slowly, as long as the action is concerted. ${ }^{149}$

To avoid such action from being a breach of the duty of good faith, the strike or lockout must be lawful. Sections 90(1), (91)(1), 93 and 94 state that a strike or lockout is lawful if

- the action is sought in relation to the bargaining of a collective agreement;

- the employees concerned are represented in the collective bargaining;

- the parties involved must not be covered by current collective agreements with a few exceptions set forth in section 86(2) of the Act;

- the parties involved have negotiated for at least 40 days; and

- if the action involves a service essential for the public interest as listed under the ERA, the notice requirement is met.

\footnotetext{
${ }^{146}$ Rudman, above n 5, at 117.

${ }^{147}$ Ibid; see Griffin v Attorney-General [1995] 4 NZELC (digest) 98, 317 (EC).

${ }^{148}$ Rudman, above n 5, at 117.

${ }^{149}$ New Zealand Air Line Pilots Assn IUOWv Air New Zealand Ltd [1998] 3 ERNZ 332.
} 
Section 80(a) of the Act alludes to the fact that unlawful industrial action could be seen as a breach of good faith. ${ }^{150}$

Unless the lockout is unlawful, employees who are locked out by their employers "are not entitled to any remuneration by way of salary, wages, allowances, or other emoluments in respect of the period of the lockout." ${ }^{151}$ Employers are permitted to suspend lawful and unlawful workers on strike, meaning that the workers are then not entitled to any remuneration for the period of suspension until the strike is over and employment resumes. ${ }^{152}$ In the situation, which an employer is not able to continue operations during a strike, it is permitted to suspend employment of non-striking workers until the strike is over. ${ }^{153}$ Under certain limited circumstances, an employer is permitted to employ or engage others to perform the work of the striking or locked out employees. ${ }^{154}$

\section{Breach of Good Faith}

Under the Code of Good Faith, when a party believes there has been a breach of good faith with regards to collective bargaining, the party should express these concerns to the breaching party early to help remedy the situation. ${ }^{155}$ Parties may also seek a penalty for a breach of good faith or apply to the Employment Relations Authority to address the breach. ${ }^{156}$

Section 4A provides that a penalty may be imposed where a party has failed to act in good faith either deliberately, in a serious and sustained manner, or in a manner that was intended to undermine the bargaining of a collective agreement or undermine an employment relationship. Where a breach of good faith has been found, section 135 provides that an individual may be fined up to $\$ 5,000$ and a company or corporation may be fined up to $\$ 10,000$.

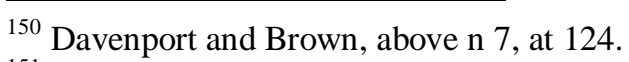

${ }^{151}$ Employment Relations Act 2000, s 96.

152 Ibid, at s 87.

${ }^{153} \mathrm{Ibid}$, at s 88 .

${ }^{154}$ Ibid, at s 97.

${ }^{155}$ Code of Good Faith in Collective Bargaining, s 6.1.

${ }^{156} \mathrm{Ibid}$, at ss 6.2 and 6.3
} 


\section{Discussions about the Impacts of Good Faith in Collective Bargaining}

\section{Introduction to Discussions about Good Faith}

As mentioned earlier, one of the stated goals of the ERA is to promote collective bargaining by requiring the parties to engage in good faith behaviour. ${ }^{157}$ Initially after the ERA was enacted, support for the duty of good faith to achieve this goal surfaced in legal literature. However, over time, this support turned into research challenging the effectiveness of the duty in protecting and promoting collective bargaining. Whether the goal to promote collective bargaining has yet been realised and whether the ERA is even capable of delivering such an outcome with its current framework continues to be a topic of debate.

Furthermore, because New Zealand's duty of good faith was inspired by the duty of good faith existing in North American jurisdictions, much literature written in New Zealand has had a comparative law element. Accordingly, arguments surrounding how the duty of good faith should be applied and interpreted in being compared with the duty of good faith in Canada and the United States have also emerged in legal literature.

The following section paints a picture of where this study will fall into the discussion of the impacts of the good faith reforms under the ERA on collective bargaining. Some of the arguments presented by other scholars and researchers are expanded upon by the findings of this author's research. Ultimately, the work of other scholars and researchers is aligned with the thesis of this study that the duty of good faith is not an effective means under the law to promote or protect collective bargaining.

It should be noted that the duty of good faith in North America has been explored extensively in other literature, but for purposes of this paper, the literature reviewed in this section was deliberately confined primarily to New Zealand. The research conducted to prove this thesis only involved unions and employers in New Zealand. Additionally, the impact of the duty of good faith on collective bargaining in New Zealand was the purpose of the research conducted for this study. Thus, the literature reviewed here does

\footnotetext{
${ }^{157}$ Employment Relations Act 2000, s 3.
} 
not have a significant comparative element and focuses mostly on work that has been done on the duty of good faith in New Zealand collective bargaining.

\section{Early Support for Good Faith and a Comparative Perspective}

Initially, the labour movement was optimistic of the good faith reforms and had expectations that they would remedy the decline of collective bargaining caused by the ECA. Naturally, support for the duty of good faith first came from the Labour Party the politicians behind the enactment of the ERA. Trade unionist and former Labour Party Speaker of the House, Margaret Wilson, wrote about the development of the ERA and the duty of good faith. By the 1980s, New Zealand's economic condition required structural reform to the industrial relations system, argued Wilson. ${ }^{158}$ "Compulsory unionism, national awards, monopoly unionism and compulsory arbitration” did not and could "not produce a productive outcome for any of the parties - employers, employees or government” in the current economy. ${ }^{159}$ The ECA was then passed, removing all statutory supports for collective bargaining. ${ }^{160}$

While change was necessary for New Zealand's economy to survive in the global market, Wilson stated that the ECA had serious detrimental impacts on unionisation and collective bargaining. ${ }^{161}$ Thus, the Labour party enacted the ERA to achieve a balance "in the relationship between employers, employees and the government."162 Wilson described the right to bargain collectively as the new focus of New Zealand's employment law, with the duty of good faith as a key element of that focus. ${ }^{163}$ While recognising that "legislation cannot change individual values or beliefs", Wilson commented that it "can, however, influence and change behaviours." The success of the legislation in doing this depends on how practical the legislation's application is in enabling affected parties to "conduct their affairs in an orderly and mutually productive

\footnotetext{
${ }^{158}$ Margaret Wilson “The Employment Relations Act: A Framework for a Fairer Way” (2001) 26 (1) NZJIR 9 at 12.

${ }^{159}$ Ibid, at 17.

${ }^{160}$ Ibid, at 12.

161 Ibid.

162 Ibid, at 19.

163 Ibid, at 15.
} 
manner."164 In 2001, one year into the ERA, Wilson believed that the ERA was achieving this goal. ${ }^{165}$

Gordon Anderson, the supervisor of this study, has been actively involved in the debate on the impacts of New Zealand's employment law reforms on collective bargaining. ${ }^{166}$ His research has investigated the impacts of both the ECA and the ERA, and he has published numerous articles on the topic over the past couple of decades.

In 2001, Anderson argued, like Wilson, that the ERA was a "relatively moderate" approach to industrial relations founded on principles established by the International Labour Organisation. The law also attempted to be more balanced than pre-1991 law. ${ }^{167}$ Anderson reminded readers that the ECA rejected the notion that an inequality exists between bargaining parties and gave unions little support for collective bargaining. ${ }^{168}$ In fact, the ECA, he wrote,

...in practice seriously undermined, collective employee rights such as the right to associate in trade unions or to bargain collectively. Instead, it gave preference to individual contracts of employment and significantly enhanced the powers of employers to deregulate and deunionise their workplaces. ${ }^{169}$

On the other hand, the objects of the ERA, commented Anderson, are a stark contrast to the ECA; instead of promoting 'an efficient labour market', the ERA promotes

\footnotetext{
${ }^{164}$ Ibid, at 18 .

${ }^{165}$ Ibid, at 12.

${ }^{166}$ See Gordon Anderson ““The Sky Didn’t Fall In’: An Emerging Consensus on the Shape of New Zealand Labour Law? (2010) 23 Australian Journal of Labour Law 94 at 96;Gordon Anderson "Transplanting and Growing Good Faith in New Zealand Labour Law" (2006) 19(1) Australian Journal of Labour Law 1-29; Gordon Anderson "The Individual and the Employment Relations Act" (2001) 26(1) New Zealand Journal of Industrial Relations 103-118; Gordon Anderson "Just a Jump to the Left? New Zealand's Employment Relations Act 2000" (2001) 14 Australian Journal of Labour Law 62-88; Gordon Anderson "Collective Bargaining and the Law: New Zealand's Employment Contracts Act Five Years On" (1996) 9 Australian Journal of Labour Law 103-134; Gordon Anderson and P Walsh "Labour's New Deal: A bargaining framework for a new century?" (1993) 18(2) New Zealand Journal of Industrial Relations 163-176; Gordon Anderson "Developments in the Legal Regulation of Collective Bargaining in New Zealand" (1990) 3(3) Australian Journal of Labour Law 227-246; Gordon Anderson "The Employment Contracts Act 1991: An employers charter?" (1991) 16 New Zealand Journal of Industrial Relations 127-142; Gordon Anderson and P. Brosnan "Freedom of Association: New Zealand and ILO Convention 87." (1984) New Zealand Law Journal 307-310.

${ }^{167}$ Gordon Anderson “Just a Jump to the Left? New Zealand's Employment Relations Act 2000” (2001) 14 Australian Journal of Labour Law 62 at $63-64$.

${ }^{168}$ Ibid, at 65.

${ }^{169}$ Ibid, at $62-63$.
} 
'productive employment relationships' and seeks to overcome the 'inherent inequality of bargaining power' existing between unions, employees, and employers. ${ }^{170}$ Most importantly, noted Anderson, the ERA features a return to collective bargaining as "the centre of industrial relations" by putting mechanisms in place to ensure that "unions and employees who wish to bargain collectively have effective legal rights” to honour that choice. ${ }^{171}$

Anderson highlighted, nevertheless, that the ERA's system of “competitive unionism” required unions to be active in organising, attracting members, and convincing workers of the importance of bargaining collectively. ${ }^{172}$ Unless unions are able to do this, Anderson remarked, the legal support in the ERA "for both unions and for collective bargaining" would be meaningless. ${ }^{173}$ Anderson also noted that the ERA did not deliver some reforms that unions were hoping for: unions were not given exclusive bargaining rights, the parties are not required to arbitrate when a breach of good faith has occurred, and strikes remain confined to enterprises. ${ }^{174}$

Gordon Anderson encouraged New Zealand to learn from the North American experience with good faith. Anderson warned that the requirement for the parties to consider and respond to proposals made by the other party could potentially be undermined by 'surface bargaining,' as has been seen from the American experience. ${ }^{175}$ "Surface bargaining occurs when one party goes through the motions of bargaining without an intention of concluding an agreement”, he explained. ${ }^{176}$ Anderson was also leery of the requirement for parties to provide information substantiating their claims, necessitating employers to provide financial information to justify their position on wages. Anderson pointed out that employers are likely to provide financial information to tailor the answer they want to receive in bargaining. ${ }^{177}$

\footnotetext{
${ }^{170}$ Ibid, at 65 .

${ }^{171}$ Ibid, at 72

${ }^{172}$ Ibid, at 69 .

${ }^{173}$ Ibid.

${ }^{174}$ Ibid, at 88 .

${ }^{175}$ Ibid, at 76 .

${ }^{176}$ Ibid.

${ }^{177}$ Ibid, at 77
} 
The damage the ECA did to collective bargaining would be difficult to reverse, Anderson noted. However, although the ERA took a "conservative and cautious” approach to remedying this situation, Anderson appreciated that the ERA, should strengthen the ability of employees who have been unable to organise under the ECA because of employer hostility and intransigence."178

Overall, Anderson welcomed the ERA in 2001 as a "return to a balanced system of labour law” that hopefully employers and employees could accept. ${ }^{179}$

Because the ERA was the first piece of legislation in New Zealand employment law history to impose a duty of good faith, much attention has been given to the North American models that have had good faith bargaining entrenched in their laws for most of the $20^{\text {th }}$ century. Some literature has been written discussing how the duty should be interpreted and applied when looking to North America for inspiration. Furthermore, support for the adoption of the duty of good faith also came from examples of good faith industrial relation systems in Canada and the United States.

New Zealand employment law specialist Geoff Davenport has written influential literature on the topic, providing explanations as to how the duty of good faith has been defined and applied in other jurisdictions throughout the world. ${ }^{180}$ Davenport's research and work on good faith in Canada has played an significant role in the development of the duty in New Zealand's ERA. At the time the ERA was being drafted, Davenport published an influential article arguing for New Zealand to adopt a similar duty of good faith as that in Canadian employment law. ${ }^{181}$

Later, once good faith was adopted, Davenport argued New Zealand could learn from Canada's decades worth of experience that good faith not only makes sense as an employment law concept without any particular political leaning, but also

\footnotetext{
178 Ibid, at 78 .

${ }^{179}$ Ibid, at 87.

${ }^{180}$ Davenport and Brown, above $\mathrm{n} 7$.

${ }^{181}$ Geoff Davenport “The Legal Obligation to Bargain in Good Faith in the New Zealand Labour Market: Rhetoric or Reality” (1999) 24(2) NZJIR 119-158.
} 
...reflects the core nature of successful employment relationships, i.e. relationships that are built on genuine engagement, openness and a recognition at least to some extent of the joint benefits of an agreed and progressive outcome to negotiations. ${ }^{182}$

Davenport promoted good faith as an ideal, self-regulating framework because the parties eventually understand "what to expect in a good faith environment.” Davenport saw good faith as a means of decreasing the need for outside intervention to handle disputes because the parties would be better situated to resolve problems amongst themselves. ${ }^{183}$

In learning from the Canadian model, Davenport observed the most common hurdles for collective bargaining in a good faith framework, and provided commentary on how these problems could possibly be avoided in New Zealand. Given the fear and sometimes animosity by an employer being faced with collectivisation for the first time, the "negotiation strength of the parties" may not always guarantee a collective agreement. ${ }^{184}$ When the parties are embarking on collective bargaining for the first time, Davenport argued that arbitration, and possibly other supporters such as facilitation, should be made readily available to ensure that the parties reach an agreement. ${ }^{185}$

Furthermore, Davenport emphasized the need for effective remedies for a breach of the duty of good faith. ${ }^{186}$ The Canadian experience demonstrates that "general compliance orders may be ineffectual to remedy breaches of good faith and promote future compliance.” ${ }^{87}$ To address this, Canada has developed “innovative” remedies such as "tailored compliance orders" to deliver "meaningful sanctions and genuine deterrence" to the breaching party. ${ }^{188}$ In providing examples of these "tailored compliance orders”, Davenport suggested that the ERA should allow express compensatory remedies for a breach of good faith in collective bargaining. ${ }^{189}$

\footnotetext{
${ }^{182}$ Geoff Davenport “Approach to Good Faith Negotiations in Canada: What Could be the Lessons for Us?” (2003) 28 (2) NZJIR 150 at 151

${ }^{183}$ Ibid, at $152-153$.

${ }^{184}$ Ibid, at 153.

185 Ibid.

${ }^{186}$ Ibid, at 155 .

187 Ibid.

${ }^{188}$ Ibid.

${ }^{189}$ Ibid, at 156.
} 
Shortly after the enactment of the ERA, Davenport teamed up with Judy Brown to write an entire book on the topic of good faith in collective bargaining. This book provides a thorough explanation of what the duty of good faith entails under New Zealand law, as well as an extensive guide on how good faith bargaining should be interpreted in New Zealand by comparative American and Canadian example. For instance, the restriction on undermining bargaining is explained by what has been determined as undermining bargaining in the United States. ${ }^{190}$ His literature continues to be used as a reference by those in industrial relations management. ${ }^{191}$

Davenport's and Anderson's comments about potential problematic areas for good faith bargaining are aligned with the findings of this study. The need for effective remedies is an area heavily discussed by the interviewees. The interviewees also discussed other problem areas such as surface bargaining and employers disclosing financial information to substantiate a claim made during bargaining. Thus, this study expands upon the problematic areas for good faith that Davenport and Anderson researched in North American jurisdictions.

\section{Literature Challenging the Effectiveness of Good Faith in Collective Bargaining}

As the law surrounding good faith in collective bargaining continues to remain the centrepiece of New Zealand's industrial relations management system and the main protection under the law for collective bargaining, criticisms and research challenging the law's effectiveness in achieving its goals also continue. Despite moving back towards a focus on the collective after many years of union-hostile laws, scholars and employment law specialists contend that these recent reforms have done little to change the state of collective bargaining in light of a continued decline in both union density and collective reach in the private sector since the enactment of the ERA. ${ }^{192}$

\footnotetext{
${ }^{190}$ Davenport and Brown, above n 7.

${ }^{191}$ A copy of Davenport and Brown's book was provided to me by the Department of Labour's Mediation Service who uses the literature in its services to employment parties.

${ }^{192}$ Anderson, above n 33, at 13.
} 
In 2006, Anderson reflected on the first six years of good faith in practice in New Zealand with the ERA and then the Amendment Act. The ERA was passed with good faith being “... envisaged as the 'oil' of the new approach to employment relations”, commented Anderson ${ }^{193}$ However, although the ERA sought to promote collective bargaining through good faith, density has fallen since its enactment. ${ }^{194}$ Anderson wrote that the Amendment Act in 2004 was passed

to attempt to address the Act's lack of success in promoting real growth in collective bargaining through discouraging freeloading and strengthening the good faith obligations." 195

Although it remained unclear whether the Amendments could improve the state of collective bargaining, Anderson believed that any change would be unlikely. ${ }^{196}$

Anderson wrote that strengthening unions' ability to organise is the key to expanding collective bargaining, which is an issue that must be addressed at the union organization level. ${ }^{197}$ Employer attitudes, enterprise size, and employee attitudes towards unionisation all impact the union's organising strength, and the 2004 Amendments did little to address these areas. ${ }^{198}$ However, Anderson held the opinion that once bargaining has commenced, the 2004 Amendments,

should prove sufficiently robust to ensure that the parties to the bargaining observe good faith. Employer behaviour may change but in many cases it is likely to change slowly amongst those who do not already have a bargaining relationship. ${ }^{199}$

Anderson saw the duty of good faith as pertinent to promoting collective bargaining, but needs further legislative support to ensure its chances of being successful. ${ }^{200}$

His most recent publication, 'The Sky Didn't Fall In' An Emerging Consensus on the Shape of New Zealand Labour Law, Anderson reiterates that the reforms in the ERA

\footnotetext{
${ }^{193}$ Anderson, above n 160, at 1.

${ }^{194}$ Ibid, at 8-9.

${ }^{195}$ Ibid, at 9-10.

${ }^{196}$ Ibid, at 28.

${ }^{197}$ Ibid.

${ }^{198}$ Ibid.

${ }^{199}$ Ibid.

${ }^{200}$ Ibid, at 29 .
} 
have had less impact on collective bargaining than the drafters envisioned, as union density continues to remain low in New Zealand.

In this piece, Anderson briefly outlines the devastating effects the ECA had on collective bargaining in such a short period of time. The ECA virtually eliminated all multi-employer arrangements by the mid-1990s in the private sector, caused union density to decline by about 30 per cent by the end of 1999, and resulted in a dramatic drop in collective bargaining coverage. ${ }^{201}$ Anderson paints a picture of the poor state of collective bargaining in New Zealand at the end of the ECA in 1999 to demonstrate that virtually nothing has changed nine years into the ERA. ${ }^{202}$ While union density fluctuated somewhat after the enactment of the ERA, by 2009, union density was at 21.5 per cent; this is almost the same density rate in 1999, nine years into the ECA. ${ }^{203}$ Anderson points out that while many factors could have contributed to a continuing decline in unionisation in New Zealand, the most dramatic decline was a result of legal reform. ${ }^{204}$ Accordingly, collective bargaining coverage is very much influenced by the shape of New Zealand's employment laws.

Although Anderson continues to find the ERA to be a step in the right direction to strengthen certain aspects of employment law, the good faith provisions still have not had a positive impact on collective bargaining density rates.

While the objective of the reforms may have been to change behaviours it became clear that the original statutory formulation of the good faith obligation had not proved fully adequate for this purpose.

Anderson cites certain barriers that still exist in New Zealand for increasing union density such as pass-on, and analyses the current insufficiencies under the law. In explaining the good faith obligations in collective bargaining and the Amendments adopted in 2004 to strengthen the effectiveness of the duty, Anderson remarks that an increase of bargaining density remains to be seen.

\footnotetext{
${ }^{201}$ Anderson, above n 33, at 5-6.

${ }^{202}$ Ibid, at 10 .

${ }^{203}$ Ibid.

${ }^{204}$ Ibid.
} 
Notably, similar to the sentiments he expressed in 2006, Anderson in his 2010 article held the opinion that the ERA established a set of rules for the parties to follow for effective bargaining once they have established a bargaining relationship; however, without being able to organise a "critical mass of employees to bargain effectively", these rules have had a limited impact on collective bargaining.

This thesis will affirm Anderson's point that an established bargaining relationship and high union density are most helpful in ensuring that the rules set forth in the ERA for effective bargaining are followed. The research conducted for this study will also expand upon this idea by revealing the experiences the parties to collective bargaining have had in practice.

Because the ERA only allows unions to negotiate collective employment agreements on behalf of only union members, Stephen Blumenfeld has stated that it is unsurprising that collective bargaining coverage has declined since the ECA and continuing into the ERA. Although this trend began before the ECA came into effect, Blumenfeld noted that the legal reform in 1991 "certainly exacerbated” the decline of collective bargaining coverage, agreeing with Anderson's position that the law had the most impact on unionisation rates. ${ }^{205}$ Blumenfeld, another industrial relations specialist who has contributed to several research studies on collective bargaining coverage trends, has remarked that,

there is little evidence to suggest that the 'good faith' requirements under the ERA, let alone the Act itself, have acted to curtail the downward trend in collective bargaining coverage. ${ }^{206}$

In fact, based on his research on declining collective bargaining coverage, Blumenfeld holds the opinion that the ERA has merely sustained the "status quo" established under the ECA, as a culture of decentralised bargaining and individualised employment relationships continue. $^{207}$

\footnotetext{
${ }^{205}$ Stephen Blumenfeld “Collective Bargaining” in Erling Rasmussen (ed) Employment Relationships: Workers, Unions, and Employers in New Zealand (new ed, Auckland University Press, Auckland 2010) 40 at 43.

${ }^{206}$ Ibid, at 54 .

${ }^{207}$ Ibid.
} 
Empirical evidence gathered since the enactment of the ERA also supports the conclusion that the future of collective bargaining remains bleak in New Zealand under the current legislation. In 2003, the New Zealand Department of Labour (DoL) conducted a comprehensive study investigating whether the ERA's objectives to promote collective bargaining through good faith had yet been realised. ${ }^{208}$ To investigate the impacts of the good faith reforms on collective bargaining, the DoL conducted surveybased research of the impacts of the ERA on collective bargaining, the perceptions of the duty, and the current state of bargaining today. ${ }^{209}$ The empirical evidence gathered from these surveys revealed that the state of collective bargaining had not improved in the first three years of the ERA. ${ }^{210}$

The DoL’s national surveys completed by employers, employees, and registered unions revealed that by 2003, most employers were aware of the duty of good faith, but had different interpretations of what was expected of them under the law. ${ }^{211}$ Unions in 2003 also essentially expressed, as they did in this study conducted in 2010, that the good faith provisions are toothless in terms of its enforcement. ${ }^{212}$ The DoL's survey indicated that employers extending the same terms and conditions to non-union employees as those in the collective agreement - a practice referred to as 'pass-on' - was what unions expressed as one of the most significant barriers to collective bargaining. ${ }^{213}$ The DoL's research pointed out that because in 2003 collective bargaining coverage had virtually remained unchanged since the ECA, the object of the ERA to promote collective bargaining had not yet been realised. ${ }^{214}$

The Industrial Relations Centre at the Victoria University of Wellington (VUW IRC) has also been gathering data on collective bargaining and publishing updates on

\footnotetext{
${ }^{208}$ Tony Waldegrave, Diane Anderson, and K Won Evaluation of the Short Term Impacts of the Employment Relations Act (Department of Labour 2003).

${ }^{209}$ Ibid, at 12.

${ }^{210}$ Ibid.

${ }^{211}$ Ibid.

${ }^{212}$ Ibid.

${ }^{213}$ Ibid, at 128 .

${ }^{214}$ Ibid, at 12.
} 
bargaining trends each year since 1993. Throughout this time period which has spanned from the first few years of the ECA into the first decade of the ERA, the Industrial Relations Centre's research has shown declining collective bargaining coverage throughout most of the last decade. ${ }^{215}$ In its most recent publication released in 2010, the VUW IRC reported a collective bargaining coverage rate of 291,500, a slight decline from the 292,100 employees reported in 2009, but a significant decline from the figure in 2006 of 320,800 employees covered by collective agreements. ${ }^{216}$

This study attempts to reveal the practical implications of the duty of good faith to help explain the statistics being published regarding declining collective bargaining density. Although many influences have impacted declining collective bargaining rates, how the law has affected bargaining behaviours will be highlighted to explain the protective strength of good faith in remedying the situation.

The insufficiencies of the duty of good faith to promote collective bargaining can markedly be apparent in the discussions among employers. One would assume that if collectivisation had a strong presence in New Zealand after the enactment of the ERA, employer interest groups would be more vocal about ways the law should be reformed to limit union activity. However, quite the opposite is true, as employer groups seem to be reasonably content with the outcomes of the ERA. Legal Adviser Barbara Burton of Business New Zealand, in her piece Employment relations 2000-2008: an employer view mentions that,

...under the ERA, the situation was not too different from that which had prevailed under the ECA....But the ERA also identifies collective bargaining as one of the means of building productive employment relationships (ERA, s 3(a)(iii)), and by the end of 2002 it was increasingly apparent that the Act was not properly fulfilling its purpose; under the Act as introduced, collective bargaining had not picked up to any great extent. Subsequently, in its submission to the 2004 Employment Relations Law Reform Bill, the New Zealand Council of Trade Unions (NZCTU)...saw 'the scale of

\footnotetext{
215 Stephen Blumenfeld, Sue Ryall, and Peter Kiely Employment Agreements: Bargaining Trends and Employment Law Update 2009/2010 (Victoria University of Wellington Industrial Relations Centre, Wellington, 2010) at 11.

${ }^{216}$ Ibid.
} 
labour market deregulation...experienced in the 1990s' as 'very difficult to reverse.",217

Employers have not noticed a dramatic difference in how they are required to conduct their behaviour with unions under the law since the enactment of the ERA, nor have they seen a perceptible increase of collective activity in their worksites - mostly because there has not been one.

Burton criticised the 2004 Amendments passed to remedy the insufficiencies of the ERA to increase collective bargaining. Although parties are required to conclude a collective agreement unless a genuine reason not to conclude exists, Burton finds what could constitute a genuine reason as "a mystery." 218 Additionally, she expressed that the Amendment which clarified that it is not a breach of good faith for an employer to agree on the same or substantially the same terms or conditions unless doing so had and was intended to have the effect of undermining the collective agreement, as a "relief" for the business community. ${ }^{219}$ Unsurprisingly, although Burton's sentiments indicate that she has not found the ERA to be particularly effective in promoting collective bargaining, she expressed that Business New Zealand remains supportive of the idea that groups of nonunion employees should be free to negotiate their own collectives. ${ }^{220}$

In representing the employer perspective, Business New Zealand has not overtly criticised the duty of good faith in collective bargaining in part because not much has changed since the ECA for employers. In fact, Burton added that since the ECA, "the demise of the award system has left many companies and other organisations quite untouched by collective activity”, despite the ERA's attempt to promote collective bargaining in New Zealand. ${ }^{221}$

\footnotetext{
${ }^{217}$ Barbara Burton “Employment Relations 2000 - 2008: An Employer View” in Erling Rasmussen (ed) Employment Relationships: Workers, Unions and Employers in New Zealand (new ed, Aukland University Press, Auckland, 2010) 94 at 96-97.

${ }^{218}$ Ibid, at 98.

${ }^{219}$ Ibid, at 99 .

${ }^{220}$ Ibid, at 98 .

${ }^{221}$ Ibid, at 104.
} 
Findings that the ERA is not delivering outcomes entirely dissimilar from the ECA could reflect on the fact that the law was not enacted to completely abandon all aspects of the ECA. Rather, it is important to remember that the ERA was designed to be a middle ground between the IC\&A Act and the ECA. In looking at the context in which the ERA was implemented, employment law researcher Jamie Latornell ${ }^{222}$ pointed out that this moderate approach was adopted to help ensure that the Act would encourage some longevity. ${ }^{223}$ Labour Party spokesperson on labour relations commented about the replacement of the ECA with the ERA that,

Our hope is to provide legislation that is sufficiently well balanced, fair and devoid of ideology that will attract wide enough support to stand the test of time. $^{224}$

Additionally, Latornell also quoted Margaret Wilson, the Minister of Labour at the time the ERA was enacted. The ERA, she stated,

...signalled the advent of a new approach to the employment relationship that built on the experiences of the 1990s as well as the values of the system of conciliation and arbitration. ${ }^{225}$

Although the ERA seeks to promote collective bargaining, it retains some commonalities with the ECA in addition to developing some new concepts such as good faith.

The ERA maintained the ECA's principles of voluntarism regarding union membership and freedom of association. ${ }^{226}$ The role of collectivism in employment relations is also maintained, as first adopted by the IC\&A Act. ${ }^{227}$ New concepts such as building productive employment relationships, mutual trust and confidence, and good faith has been added to these old concepts ${ }^{228}$

\footnotetext{
${ }^{222}$ Jamie Latornell is the Academic Director (Management \& Economics) in the Manukau Business School at the Manukau Institute of Technology, Auckland, New Zealand.

${ }^{223}$ Jamie Latornell "Uncovering the Origins of New Zealand's Employment Relations Act 2000: A Research Framework” (2006) 31 (3) NZJER 88 at 88.

${ }^{224}$ Ibid, at 88.

${ }^{225}$ Ibid.

${ }^{226}$ Ibid, at 92 .

${ }^{227}$ Ibid, at 96 .

${ }^{228}$ Ibid, at 97.
} 
In retaining some of these aspects, perhaps the ERA is also retaining some of the effects of the ECA, as reflected in declining collective bargaining rates. This thesis will also expand on these ideas that the state of collective bargaining has not substantively changed since the days of the ECA. The interviewees will comment that although on the surface collective bargaining behaviour has changed, in practice, good faith has not had a meaningful impact on collective bargaining.

\section{Conclusion of Commentators on Good Faith}

Employment law specialists from all ends of the spectrum seem to agree that after the ECA, the ERA was a step in the right direction towards providing a less hostile employment law environment for collective bargaining in New Zealand. However, the good faith reforms have had limited success and ultimately fall short of bringing New Zealand into an environment in which collective bargaining is unobstructed.

Literature written and research conducted on the impacts of good faith on collective bargaining provide that there is reason to believe that any positive impact on collective bargaining rates will require additional legislative reform. This study furthers this idea by providing empirical evidence that the protective strength of good faith for collective bargaining is minimal. The good faith provisions are broken down individually to discuss the experiences of the parties to collective bargaining with regards to each provision. The parties' experiences discussed in this study reveal the effectiveness of individual provisions in improving the collective bargaining process, highlighting areas that could benefit from stronger legislative reform. 


\section{THE CURRENT STATE OF COLLECTIVE BARGAINING IN NEW ZEALAND}

\section{A. Introduction to the State of Collective Bargaining Statistics}

The current state of collective bargaining puts into context the research and thesis being offered in this study. Accordingly, the experiences of unions and employers with collective bargaining under the ERA as provided in the Results Chapter of this paper should be digested with the backdrop of the following information on collective bargaining density.

As mentioned earlier, the Victoria University of Wellington Industrial Relations Centre (VUW IRC) has been releasing reports annually since 1993 focused on the overall effects of the current employment laws on collective bargaining outcomes. ${ }^{229}$ The statistics provided in these reports depict the current bargaining trends and overall collective bargaining coverage throughout New Zealand.

The specific information being discussed in this section is the IRC's statistics on bargaining coverage. Bargaining coverage refers to the number of employees covered by collective agreements in New Zealand.

The VUW IRC collected this data from questionnaires completed by local union organisers and workplace representatives who negotiated the collective agreement. ${ }^{230}$ When interpreting this data, it should be kept in mind that no data collection study of this nature can be 100 per cent accurate. The VUW IRC noted there may exist some problems with their data collection method in terms of the reporting union organiser not being fully informed of the exact number of employees a collective agreement has been extended to or their data perhaps missing collective agreements that the reporters were unaware of. ${ }^{231}$

\footnotetext{
${ }^{229}$ Blumenfeld, Ryall, and Kiely, above n 231, at 11.

${ }^{230}$ Ibid, at 12.

${ }^{231}$ Ibid, at 13.
} 
The data being received for the VUW IRC's report is provided on a voluntary basis, so naturally the numbers will be incomplete. ${ }^{232}$

The statistics being discussed in this chapter were the most recent bargaining trend statistics available by the VUW IRC when this thesis was being written. Accordingly, the bargaining trends of 2009 and 2010 as reported on by the VUW IRC are being relied on to provide context of this thesis' results.

\section{B. The Public-Sector and Private Sector Divide}

Before discussing the results provided in the 2009/2010 bargaining trends report, the great public-sector to private-sector collective bargaining coverage disparity warrants a brief mention. Generally, a considerably greater proportion of public sector workers than private sector workers have been covered by collective agreements throughout New Zealand history. As mentioned in VUW IRC's report, public sector collective bargaining peaked at 97 per cent before the 1980s, whereas private sector collective bargaining density was at around 50 per cent under the conciliation and arbitration system. ${ }^{233}$ However, the ECA in 1991 reduced private sector coverage to around 21 per cent, whereas public sector coverage remained high.

Today, the public sector represents around 61 per cent of the total employee coverage by collective agreements in New Zealand and maintains a 59.2 per cent of collective bargaining coverage. ${ }^{234}$ Unlike the private sector, bargaining coverage percentages in the public sector have been increasing steadily since $2004 .{ }^{235}$ Thus, both collective bargaining density and union membership rates remain concentrated to mostly the public sector. ${ }^{236}$

\footnotetext{
${ }^{232}$ Ibid.

${ }^{233}$ Ibid, at 19 .

${ }^{234}$ Ibid.

${ }^{235}$ Ibid.

${ }^{236}$ Ibid.
} 


\section{The Current State of Collective Bargaining in New Zealand}

In 2010, the VUW IRC reported that a total of 291,500 employees in New Zealand were covered by collective agreements. ${ }^{237}$ This number represents the lowest total number of employees covered by collective agreements since the VUW IRC began reporting in the early 1990s, when the ECA was still in force. ${ }^{238}$

In the public sector, collective bargaining density remains substantial. 59 per cent of employees in the public sector are covered by collective agreements. This percentage represents a 3 percent increase from 2009.

The most notable changes in collective bargaining trends reported by the VUW IRC occur in the private sector. The New Zealand private sector has experienced a dramatic decline of collective bargaining coverage over the past two decades. Of the 291,500 employees covered by collective agreements reported in 2010,114,100 of those employees are in the private sector; this number means that a mere eight per cent of employees in the private sector are covered by collective agreements.

Particularly, the eight per cent 2010 bargaining density in the private sector should be compared with the 21 per cent of employees that were covered by collective agreements in the private sector in 2000 when the ERA was enacted. Additionally, this eight per cent collective bargaining density is much lower than the 21 per cent collective bargaining density reported in 1995, five years into the ECA.

\section{The Significance of the Current State of Collective Bargaining in New Zealand}

The following information proves that, in the numbers, the good faith provisions under the ERA have not increased collective bargaining. In fact, collective bargaining density has dramatically decreased since the enactment of the ERA. Accordingly, the

${ }^{237}$ Ibid.

${ }^{238}$ Ibid. 
goal of the ERA to promote collective bargaining has not been realized in the first 10 years of the Act.

The research conducted in this thesis attempts to make sense of these numbers. In meeting with unions and employers to understand their experiences with collective bargaining under the ERA's good faith provisions, some light can be shed on how the law has perhaps contributed to the decline in collective bargaining density.

\section{Background Information of the Results}

\section{A. The Value and Focus of this Interview-Based Study}

As discussed earlier, many New Zealand academics and labour law specialists have been sceptical of the benefits of the good faith reforms to collective bargaining, while others have provided evidence that the state of collective bargaining has not improved since the enactment of the ERA. Also, much literature has been written regarding what all the good faith provisions in the ERA entail.

Although the duty of good faith applies to all aspects of the employment relationship and there is significant literature written on good faith as it is allencompassing in its applicability, the focus of this study does not expand outside of collective bargaining. Accordingly, the research discussed in this chapter is limited to the topic of good faith in collective bargaining.

Ample literature on good faith in collective bargaining under the ERA is available already, and the Department of Labour has conducted similar studies that have interviewed the parties to collective bargaining to discover the impacts of the ERA. ${ }^{239}$ However, this is the most recent study and the focus is solely on the experiences of the

\footnotetext{
${ }^{239}$ See Department of Labour The Effect of the Employment Relations Act on Collective Bargaining (July 2009).
} 
parties to collective bargaining with good faith. Additionally, my legal research did not reveal that similar studies exist in the United States of America or Canada, two jurisdictions where the parties have been bound to a duty of good faith in collective bargaining for decades.

\section{B. Assistance for the Study}

The time, efforts, and generosity of several contributors in New Zealand and the United States have made this study possible. The participants to this study, the methods used in determining the participants, the limitations of the study, and other contributing factors, which made this study possible, are discussed below.

\section{Funding for the Study}

The research costs associated with this study, funding for all my living expenses for my time in New Zealand, and general assistance in establishing Wellington as the base for this project have all been provided by the William J. Fulbright Fellowship Program administered by the United States Department of State. This study is also being used toward completion of my LLM degree at Victoria University of Wellington, tuition expenses of which were also generously covered by my Fulbright grant.

Ten months into this study, my Fulbright grant period concluded and the Victoria University of Wellington generously stepped in to provide funding to accommodate the final three months of this study. Without the generosity of these two organizations, this study would not have been possible.

\section{Supervisory Assistance, Advice, and Review}

Victoria University of Wellington is one of the foremost universities in New Zealand for the study of industrial relations. It was under Victoria's LLM by thesis program that this study was conducted. Once supervisory assistance was offered by 
Victoria University of Wellington, the Fulbright Fellowship Program and later Victoria University offered to financially support the study.

As a faculty member of Victoria University of Wellington's internationally renowned industrial relations and employment law team, Professor Gordon Anderson at the Faculty of Law served as the supervisor of this entire study providing intellectual guidance and suggestions for its completion. Anderson teaches Employment Law, International Trade Law, and International and Comparative Labour Law at Victoria, in addition to conducting research and being published on his work on the nature and impacts of New Zealand's labour laws since the 1990s.

Dr. Amanda Reilly joined in to provide additional supervisory assistance from the Victoria University of Wellington's School of Accounting and Commercial Law where she teaches the Law of Work and Business Contracts. Reilly has conducted research and written publications in the broad area of legal responses to the changing nature of work.

Additionally, Victoria University of Wellington provided administrative support and academic resource support for writing the thesis. Victoria's Pipitea Human Ethics Committee approval was granted in May of 2010, allowing for the interviews for this study to be conducted with unions, public officials, and employers. Accordingly, all of the interviews used for this study were conducted in compliance with the confidentiality and ethical standards as set forth by the Human Ethics Committee at the University of Victoria of Wellington.

\section{External advice}

The New Zealand Department of Labour (DoL) provided assistance in setting up meetings with public sector stakeholders for purposes of this study in addition to providing information gathered by the Department in their previous studies completed about collective bargaining under the Employment Relations Act. Several of the 
publications completed by the DoL regarding their research on the topic of good faith are referenced in this study.

\section{Limitations of this study}

There were a number of factors limiting the scope and depth of this study that, while should not diminish the value of what is actually being presented, should be kept in mind while reading this paper.

\section{Time and Administrative Restrictions}

One individual, a recent American law school graduate from the United States in New Zealand over the course of ten months conducted this entire study including all the interviews and research. Naturally, the limitations presented by conducting such a large study alone in a ten month time period imposed limitations on the extensiveness of the study.

In being an outsider to the New Zealand employment relations system, this study was administered impartially with a unique outsider-looking-in perspective. Additionally, in having worked only in American labour relations, this study also was able to have a comparative element. While being a foreigner doing a study of New Zealand labour law has its benefits, this analysis may be different than a specialist in New Zealand labour relations or someone having studied and worked in New Zealand industrial relations longer than 10 months.

2. Scope limited to the Employment Relations Act, subsequent laws regulating good faith in collective bargaining, and the Code of Good Faith

This study was limited to investigating the degree to which certain outcomes have occurred because of the Employment Relations Act's duty of good faith. It should be understood that many other influences could have impacted union density and employment relations between unions and employers in New Zealand; however, other 
influences besides the ERA logistically were not explored for purposes of this paper. These other influences might include:

- Public sentiment towards unions in New Zealand

- Changes in the New Zealand economy and unemployment rates

- Industry structures impacting the size of traditional union bases

- The limited time frame in which the ERA has been in place

- Other socioeconomic factors which might impact employment relations An economic analysis of unionization is also outside of the scope of this study. This study's focus is limited to the impacts of the duty of good faith legal reforms on collective bargaining.

\section{Methodology}

\section{Methodology Introduction}

Interviews were conducted with unions, employers, union interest groups, employer interest groups, and officials at the New Zealand Department of Labour to determine whether the good faith provisions have been helpful in facilitating collective bargaining and the processes before and after bargaining. The purpose of these interviews was to determine if the goals of the ERA and 2004 Amendments have been realized at all since their enactment, including:

- Assess the extent to which parties are using Bargaining Process Agreements (BPA) and whether BPAs have been helpful for the parties involved

- Assess whether good faith is a tool to facilitate collective bargaining

- Assess whether union membership is increasing due the good faith provisions aimed at promoting collective bargaining, and if not, what are the impediments for collective bargaining

- Assess how the concept of individual choice is impacting union's organising efforts and whether good faith is recognised with regards to free choice

- Assess whether problems with "freeloading" or "passing on" still occur 


\section{Choosing the interviewees for this study}

The interviewees for this study were chosen based on a number of factors. The parties to collective bargaining were targeted as the main participants to be interviewed for this study. Accordingly, employers and unions were the general target of the study. Due to time restraints, individual employees were not interviewed.

The main factor determining the contributors for this study was willingness to participate. Most of the major unions and employers throughout New Zealand were asked to comment or participate in an interview, but several did not respond. Because participation to this study was designed to be entirely voluntary, if a party chose not to respond to an initial contact made by the author, no further communication was made to this party. If a party did respond, an interview time and date was set up for the author to meet with the interviewee.

Employers generally were chosen based on the union activity at their worksite. Some employers were targeted by this study based on the fact that they had an industrial dispute within the past couple of years with a union. Along these lines, if the industrial dispute was related to good faith, the employer was targeted for this study.

When the author of this study made an initial contact to an employer or union, the party being contacted could generally choose whom they wanted to comment in the interview at their organisation. The author requested that the party being interviewed have a general knowledge of the impacts of good faith on collective bargaining. Ultimately, the decision who would represent the organization in the study was made by the union or employer based on who was willing and able to informatively discuss good faith in collective bargaining.

More unions contributed to this study than employers even though just as many employers were asked to participate for the simple reason that many large employers 
were concerned with confidentiality. Business New Zealand, in representing the interests of many major employers throughout the country belonging to this group’s membership, served as a substitute for having an equal number of employers and unions contributing to this study.

The unions chosen for this study were all unions belonging to the New Zealand Council of Trade Unions mostly because their contact information was readily available on the Internet. Gordon Anderson, the main supervisor for this study, provided the author with the contact information of several union officers with experience in good faith in collective bargaining. Typically, larger unions had more information about their membership on the Internet and this information made them easier to contact.

\section{The structure of the interview}

Most of the interviews for this study were conducted in person, face-to-face at the union headquarters, the employer's office, or respective place of business. If the union or employer's headquarters were located outside of Wellington, an interview was conducted over the phone.

The parties were asked about their experiences and opinions regarding certain good faith provisions surrounding collective bargaining as set forth in the Employment Relations Act and subsequent legislation. The parties were also asked which good faith provisions were particularly problematic for them during collective bargaining and how the law could be reformed to improve the collective bargaining process. The parties were asked to comment on, if good faith is not an indication that collective bargaining will go well, then what factors do help collective bargaining. Lastly, the parties were asked their opinions about what the good faith reforms were doing for unionisation rates in New Zealand, i.e., why they thought unionisation has not increased since the implementation of the good faith reforms under the ERA even though the goal of the Act was to promote collective bargaining. 
The comments provided in this study were impacted by how forthcoming the participant was during the interview. The interviewee could provide as much or as little information as they wanted regarding their opinions and experiences with the good faith provisions under New Zealand employment law.

\section{E. Profile of Participants}

\section{Union Participants}

This study attempted to interview all of the major unions currently serving as collective bargaining agents for workers in New Zealand. Due to time constraints, not every union in the country was interviewed. However, despite having to leave some out, the trends in this study reflect that most unions in New Zealand have had the similar experiences with good faith depending on their industry. Several trends also emerged depending on whether the employer and union had workers in the public sector or private sector. Clear divisions with regards to collective bargaining rates were apparent between the public and private sectors.

The following unions participated in this study:

(a) The Service and Food Workers Union Nga Ringa Tota

The Service and Food Workers Union Nga Ringa Tota (SFWU) represents a broad range of mostly unskilled workers in both the private and public sectors. ${ }^{240}$ In 2009, SFWU had 26,065 members. ${ }^{241}$ Their membership is similar to the Service Employees International Union (SEIU) in the United States. SFWU organizes in favour major sectors:

(i) Age Care, Disability, Health \& Community Services

- Including those working in rest homes, retirement villages, private and public hospitals, dental offices, mental, physical and intellectual disability care facilities, and community and voluntary agencies

\footnotetext{
${ }^{240}$ Dannin, above n 28, at 65.

${ }^{241}$ Department of Labour Union Membership Return Report 2009 (2009).
} 
(ii) Catering, Cleaning and Contract Services

- Including parking attendants

(iii)Clerical, Administration \& Technical Services

- Including parking attendants

(iv)Clerical, Administration \& Technical Services

- Such workers in the private sector including airline workers, office workers, call centres, passenger and reservations staff, helpdesks, information technology staff, etc.

(v) Food \& Beverage Manufacturing \& Processing

(vi) Hospitality, Tourism \& Entertainment Services

- Including hotel, motel, pubs, fast food restaurants, clubs, casinos, flight catering, tourism, theatres, leisure and theme park workers and musicians in all genres of bands and orchestras ${ }^{242}$

SFWU members run their own affairs at national, regional, and district levels. Members elect their own delegates and union officers, vote on the policy and direction of the union and have the final say on collective agreements. The union's governing bodies are the National Executive and the Regional Executives, and they are made up of the elected members from each region and within regions, from each industry group. Women, Pacific Islander, and Maori representatives have positions on each Executive. ${ }^{243}$ The SFWU is affiliated with the New Zealand Council of Trade Unions. ${ }^{244}$

In 1990 before the ECA, the union represented approximately 70,000 workers. ${ }^{245}$ By May of 1991 a year into the enactment of the ECA, SFWU's membership plummeted to $25,900 .{ }^{246}$ By 2000, membership had sunk to 20,000. ${ }^{247}$ Alaister Duncan of the SFWU analogized the membership rates of the union from the ECA to the ERA to the dropping of a dead rat off a building:

You drop the dead rat from a great height and it bounces. And that's what happened with union membership in Service and Food Workers Union. ${ }^{248}$

\footnotetext{
${ }^{242}$ Service and Food Workers Union Nga Ringa Tota “About SFWU” <http://www.sfwu.org/>.

${ }^{243}$ Ibid.

${ }^{244}$ New Zealand Council of Trade Unions CTU Affiliates (2010) About Us <http://union.org.nz/about/ctuaffiliates>.

${ }^{245}$ Dannin, above n 28, at 65.

${ }^{246}$ Ibid.

${ }^{247}$ Interview with Alaister Duncan, SFWU Central Region Secretary (Julie Polakoski, 17 September 2010) transcript provided by Julie Polakoski.

${ }^{248}$ Ibid.
} 
According to Duncan, two years into the ERA, SFWU membership rose to about twenty three to twenty-four thousand. Then nationally, the membership numbers began to decline and continue to do so. Duncan stated that the SFWU loses about three or four hundred members a year. ${ }^{249}$ As of 2009, membership is about 22,800. ${ }^{250}$

Alastair Duncan, the Service and Food Workers Central Region Secretary, was interviewed for this study. Duncan has worked as a full time union advocate since 1978. He has worked with unions in New Zealand, England and the United States experiencing a broad range of good and bad faith. ${ }^{251}$

\section{(b) FinSec}

FinSec represents finance workers all across New Zealand in banks, insurance companies and finance companies. ${ }^{252}$ As of March of 2009, FinSec had 5,381 members. ${ }^{253}$ From the union's perspective according to Andrew Cassidy, FinSec organizes in a "very well-defined industry made up of, for the most part, large corporates and deep multi-nationals.” 254 FinSec is affiliated with the New Zealand Council of Trade Unions. ${ }^{255}$ FinSec's motto is that the union is run by its members for its members. ${ }^{256}$

Andrew Campbell with FinSec was interviewed for this study. Campbell started working for FinSec March of 2005 as Lead Organiser, overseeing the implementation of the union's work in the central region of New Zealand. In 2006, Campbell then became FinSec's Campaigns Direction, a role in which he is responsible for:

(i) the union's long term industry planning

(ii) developing the union's annual plan

\footnotetext{
249 Ibid.

${ }^{250}$ Department of Labour, above n 256.

${ }^{251}$ Interview with Alaister Duncan, SFWU Central Region Secretary (Julie Polakoski, 17 September 2010) transcript held by author.

${ }^{252}$ FinSec "Where I Work" < http://www.finsec.org.nz>.

253 Department of Labour, above n 256.

${ }^{254}$ Interview with Andrew Campbell, FinSec Campaigns Director (Julie Polakoski 11 June 2010) transcript held by author.

${ }^{255}$ New Zealand Council of Trade Unions, above n 259.

${ }^{256}$ FinSec, "Finsec - the union for workers in the finance sector" About FinSec $<$ http://www.finsec.org.nz/About+Finsec $>$.
} 
(iii) developing and implementing bargaining and other campaigns

(iv) developing and implementing the union's political strategy

(v) being the union's public spokesperson in the media

(vi) supporting and developing the union's organizing

Prior to his work with FinSec, Campbell worked two years as a union organiser for the Association of University Staff at the Massey University campus located in Palmerston North. $^{257}$

Andrew Casidy of FinSec was also interviewed for this study. Casidy began his career with FinSec, which was then called the Bank Officer’s Union, in late 1987 as an organiser. This position entailed running meetings, resolving workplace problems through organising at a local level, delegate development and education, grievance handling etc. In 1997, Casidy changed roles in the union to become the national organiser which entailed being responsible for the union's activities in certain nation-wide employers, acting as an advocate during collective bargaining, resolving national problems within those employers, etc. In 2002, Casidy became the Assistant General Secretary with management responsibility for the unions organising staff whilst retaining his national organiser duties. Then in 2003, Casidy took on his current role with FinSec as the union's General Secretary. Prior to working for FinSec, Casidy was involved in the labour movement as an elected workplace delegate to the union from 1985 to 1987, participating in one of the largest strikes the financial sector ever had in $1985 .{ }^{258}$

(c) Unite

As Unite organizer Oman Hamed has stated, Unite is known in New Zealand for "organizing the un-organisable industries." ${ }^{, 59}$ Although Unite is a relatively new union in New Zealand, it is also the fastest growing private sector union in the country. Having

\footnotetext{
${ }^{257}$ Interview with Andrew Campbell, FinSec Campaigns Director (Julie Polakoski 11 June 2010) transcript held by author.

${ }^{258}$ Interview with Andrew Casidy, FinSec General Secretary (Julie Polakoski 28 June 2010) transcript held by author.

${ }^{259}$ Interview with Omar Hamed, Unite Organiser (Julie Polakoski 19 July 2010) transcript held by author.
} 
been established in 2004, Unite has grown to 11,700 by March of $2009 .^{260}$ Unite’s membership consists of workers working in:

- Fast food restaurants

- Call centres

- Casinos

- Cinemas

- Security

- Language schools

- Retail

- Hospitals

- $\quad$ and more... ${ }^{261}$

Additionally, Unite is open to workers who have changed jobs or left the workforce. ${ }^{262}$ Because of the types of workplaces Unite organises, their members tend to be fairly young; for many of their members, belonging to Unite is the first time they have belonged to a union or been aware of the labour movement in New Zealand. ${ }^{263}$ Unite's membership would most likely be larger if there were not such a large turnover in the workplaces that Unite organises.

Unite is unique among unions in New Zealand because of their strong organizing methods and outspoken campaigning on numerous labour related issues. In the duration of this study, Unite's name was at the forefront on the campaign to raise the minimum wage to a "living wage" - a wage high enough for an adult in a full time job to maintain a reasonable standard of living without going into debt or relying on charity or income support. ${ }^{264}$ Unite's work is also quite noticeable for their active participation in lively protests against the National government for their positions to amend the current labour laws to make them more restrictive for workers. Unite is affiliated with the New Zealand Council of Trade Unions. ${ }^{265}$

\footnotetext{
${ }^{260}$ Marcela Escauriaza “New Zealand: Unite Takes on Minimum Wage” (2010) Green Left $<$ http://www.greenleft.org.au/node/43155> ; see also Department of Labour, above n 226.

${ }^{261}$ Unite "Who is Unite?" <http://www.unite.org.nz/node/165>.

${ }^{262}$ Unite "Who is Unite?" About Us <http://www.unite.org.nz/node/165>.

${ }^{263}$ Interview with Omar Hamed, Unite Organiser (Julie Polakoski 19 July 2010) transcript held by author.

${ }^{264}$ Unite "Unite’s \$15 an hour Campaign for a Living Wage” Campaign for a Living Wage $<$ http://www.unite.org.nz/livingwage>.

${ }^{265}$ New Zealand Council of Trade Unions, above n 259.
} 
Omad Hamed, a union organiser for Unite, was interviewed for this study. Hamed has held this job with Unite for the past two and a half years. He became involved in the labour movement at age 16 as an activist in Unite’s Supersize My Pay Campaign, and has been involved ever since (he’s 23 years old). ${ }^{266}$

(d) The New Zealand Amalgamated Engineering, Printing and Manufacturing Union

The New Zealand Amalgamated Engineering, Printing and Manufacturing Union (EPMU) is New Zealand's largest private sector union representing, as of 2009, 41,394 workers throughout the country. ${ }^{267}$ The EPMU represents workers across 11 different industries, including:

(i) Engineering

(ii) Manufacturing

(iii) Print \& Media

(iv) Energy \& Mining

(v) Timber

(vi) Food

(vii) Postal \& Logistics

(viii) Electrocomms

(ix) Plastics Public Service \& Infrastructure

(x) Aviation 268

The EPMU was first formed in 1996 when the Engineers' Union merged with the Printing, Packaging and Manufacturing Union and the Communications and Energy Workers Union. The EPMU is affiliated with the New Zealand Council of Trade Unions. $^{269}$

National Industry Organiser Paul Tolich from the EPMU was interviewed for this study. Tolich first became involved in the labour movement in 1970s as a union organiser and has remained involved in some capacity ever since. He has worked in labour through all the major New Zealand employment law reforms including the

\footnotetext{
${ }^{266}$ Interview with Omar Hamed, Unite Organiser (Julie Polakoski 19 July 2010) transcript held by author.

${ }^{267}$ Department of Labour, above n 256.

${ }^{268}$ EPMU "Home" < http://www.epmu.org.nz/>.
} 
Industrial Relations Act, the Labour Relations Act, the Employment Contracts Act, and now the Employment Relations Act. ${ }^{270}$

(e) The New Zealand Tramways and Public Passenger Transport Employees Industrial Union

The New Zealand Tramways Union represents bus drivers in the Wellington, Auckland, and Dunedin regions. The union was founded in Auckland in 1903 and started its Wellington branch in 1908, and as of March of 2009, comprises of 1,150 members. ${ }^{271}$ According to Wellington's President Nick Kelly, the union’s branches have become fairly autonomous in recent years since the national union became less active after the decline and fall of the awards system in New Zealand. ${ }^{272}$ At present, the union remains registered as a national union and the separate branches work together. ${ }^{273}$ The NZ Tramways and Public Transport Union is affiliated with the New Zealand Council of Trade Unions. ${ }^{274}$

Nick Kelly from the Wellington branch was interviewed for this study. Kelly served as President of the Victoria University of Wellington Student's Association up until 2006 before coming involved with politics and the labour movement. Kelly is now a bus driver and President of the Wellington Tramways Union. ${ }^{275}$

\footnotetext{
${ }^{269}$ New Zealand Council of Trade Unions, above n 259.

${ }^{270}$ Interview with Paul Tolich, EPMU National Industry Organiser (Julie Polakoski, 16 September 2010) transcript held by author.

${ }^{271}$ Department of Labour, above n 256.

272 Interview with Nick Kelly, Wellington Tramways Union President (Julie Polakoski, 28 September 2010) transcript provided by Julie Polakoski.

273 Ibid.

${ }^{274}$ New Zealand Council of Trade Unions, above n 259.

275 Interview with Nick Kelly, Wellington Tramways Union President (Julie Polakoski, 28 September 2010) transcript held by author.
} 
(f) The New Zealand Tertiary Education Union - Te Hautu Kahurangi o Aotearoa Takitini o Aotearoa

The Tertiary Education Union (TEU) was founded in 2009 after the amalgamation of the Association of University Staff (AUS) and the Association of Staff in Tertiary Education (ASTE). ${ }^{276}$ Both of these previous organisations that merged to become the TEU have a long history of representing New Zealand workers in tertiary education. ${ }^{277}$ As of 2009, membership included 10,238 workers. ${ }^{278}$ AUS was established in 1923 as the Association of University Teachers (AUT). ${ }^{279}$ In 1989, the Association of New Zealand University Library Staff merged with AUT and then in 1992, the New Zealand University Technicians Union also merged with AUT to become AUS. ${ }^{280}$ ASTE was founded in 1960 as the Association of Teachers in Technical Institutes (ATTI), and then changed its name to the New Zealand Association of Polytechnical Teachers (NZAPT) in the 1980s. ${ }^{281}$ The NZAPT then merged with the Teacher Colleges Association in 1998 to form ASTE. ${ }^{282}$ During the Employment Contracts Act, ASTE extended its membership to private education staff, wānanga, and other tertiary educators. $^{283}$

Today, the TEU represents more than 12,000 workers employed in tertiary education all throughout New Zealand. ${ }^{284}$ Their membership includes workers employed in all of the occupations represented in universities, polytechnical schools, technology institutes, wānanga, and other tertiary education providers and related organizations. ${ }^{285}$ The TEU is affiliated with the New Zealand Council of Trade Unions. ${ }^{286}$

\footnotetext{
276 Tertiary Education Union, “History” About < http://teu.ac.nz/about/history/>.

277 Ibid.

${ }^{278}$ Department of Labour, above n 256.

279 Tertiary Education Union, above n 243.

280 Ibid.

281 Ibid.

282 Ibid.

283 Ibid.

${ }^{284}$ Ibid; see also Department of Labour, above n 256.

285 Tertiary Education Union, above n 243.

${ }^{286}$ New Zealand Council of Trade Unions, above n 259.
} 
A union organiser for the TEU who wished to have their name withheld was interviewed for this study. Organiser has worked in this capacity with the TEU since 2001. Organiser has been involved with the labour movement since 1985 when he was Vice President of another union in the private sector. ${ }^{287}$

(g) New Zealand Public Service Association

The Public Service Association (PSA) is one of the oldest unions in New Zealand, representing close to 58,000 workers employed by government departments, local governments, the public health sector, crown agencies, state-owned enterprises and publicly funded agencies today. ${ }^{288}$ PSA claims that it is the largest union in New Zealand and the largest in the public sector. ${ }^{289}$ The PSA is affiliated with the New Zealand Council of Trade Unions. ${ }^{290}$

PSA national union organiser Jim Jones was interviewed for this study. Jones has been with the PSA for the past four years as an organizer at the Ministry of Social Development and currently the IRD and the Ministry of Justice. Jones has been involved in the labour movement for the past 35 years as a union organiser and has held several officer positions with different unions. ${ }^{291}$

(h) National Distribution Union

The National Distribution Union (NDU) was formed in 1986 when the Northern Drivers Union, the Northern Stores and Warehouse Union, the Auckland and Gisborne

\footnotetext{
${ }^{287}$ Interview with TEU Union Organiser (Julie Polakoski, 17 June 2010) transcript held by author.

${ }^{288}$ New Zealand Public Services Association "What We Stand For” About Us <http://www.psa.org.nz/AboutUs/whatwestandfor.aspx> ; see also Department of Labour, above n 226.

${ }^{289}$ New Zealand Public Services Association “PSA Overview” PSA Operating Manual 2010 $<$ http://operating.psa.org.nz/node/5>.

${ }^{290}$ New Zealand Council of Trade Unions, above n 259.

${ }^{291}$ Interview with Jim Jones, PSA Organiser (Julie Polakoski, 20 July 2010) transcript held by author.
} 
Shop Employee Union and the Northern Butchers and Grocers Union merged together. ${ }^{292}$ Several other unions amalgamated with the NDU over time as well, including:

- South Island Clothing Workers Union

- Distribution \& General Workers Union

- $\quad$ NZ Engine Drivers Union

- Northern Textile \& Clothing Workers Union

- Performance \& Entertainment Union

- The Wood Industries Union of Aotearoa

- South Bakers Union ${ }^{293}$

As of 2009, the NDU comprised of 20,589 members employed in the private sector. ${ }^{294}$

Robert Reid, the National Secretary of the NDU described the union for this study:

"We're the National Distribution Union, and as the name suggests, we began as a union covering workers in driving, storeworkers.....and then shopworkers.... and subsequent to that time, we've become a more general union. We've had workers in the woods sector, timber workers affiliating, joining us, and also in the textile and clothing sector joining us. We're a national union.... third party logistics have been a major area, waste and recycling workers we cover... Our biggest sector, and it's almost coming up to be half of the union, is shopworkers, and we have members there in one of the major supermarket chains.”295

According to Reid, the NDU began in the Auckland region where its presence continues to be strongest in all of New Zealand. ${ }^{296}$ The NDU is affiliated with the New Zealand Council of Trade Unions. ${ }^{297}$

Robert Reid, the National General Secretary (Chief Executive Officer) of the NDU was interviewed for this study. Reid has held this position since 2009, and served as President of the NDU from 2007 to 2009. Prior to working for the NDU, Reid was

\footnotetext{
${ }^{292}$ National Distribution Union “Our History” About Us <http://ndu.org.nz/our_history>.

${ }^{293}$ Ibid.

${ }^{294}$ Department of Labour, above n 256.

${ }^{295}$ Interview with Robert Reid, NDU General Secretary (Julie Polakoski, 15 June 2010) transcript held by author.

${ }^{296}$ Ibid.

${ }^{297}$ New Zealand Council of Trade Unions, above n 259.
} 
actively involved in the labour movement in some way or another beginning in 1971 when he was President of the New Zealand University Students Association and Victoria University Students Association. Since then, he's held positions with the Green Party, the Board of Textiles NZ, the Commonwealth NGO Forum in Wellington, the Association of Non Government Organisations of Aotearoa (ANGOA), the Wellington Footwear Workers Union, the NZ Council of Trade Unions, the Wellington District Council of Trade Unions, the Wellington District Employment and Training Advisory Committee, the Wellington Regional Employment and Access Council, the Wellington Engineers Union and Wellington Trade Council, just to name a few. ${ }^{298}$

(i) New Zealand Meat Workers \& Related Trades Union Inc.

In 2009, the New Zealand Meat Workers and Related Trades Union Inc. covered 18,456 permanent and seasonal workers during peak season. ${ }^{299}$ These members are employed in over 75 sites throughout the New Zealand meat industry. ${ }^{300}$ This includes workers in freezing works, tanneries, fertiliser plants, halal operations, small meat processing plants and small goods processors. ${ }^{301}$

Meat Workers have a long history of collectivism in New Zealand. Slaughterers were first to form a union in the New Zealand meat industry and were able to gain their first collective agreement in Canterbury in $1901 .^{302}$ Chamberhands and Slaughtermens Assistants entered into award agreements next and by 1912, all of these individual unions formed into district unions. ${ }^{303}$ It was then decided to form a National Organisation, the New Zealand Freezing Workers Association in 1920, which made the first National

\footnotetext{
${ }^{298}$ Interview with Robert Reid, NDU General Secretary (Julie Polakoski, 15 June 2010) transcript held by author.

${ }^{299}$ Department of Labour, above n 256; see also New Zealand Meat Workers and Related Trades Union Inc. "Welcome" <http://www.nzmeatworkersunion.co.nz/>.

${ }^{300}$ New Zealand Meat Workers and Related Trades Union Inc. "Welcome” $<$ http://www.nzmeatworkersunion.co.nz/>.

${ }^{301}$ Ibid.

${ }^{302}$ New Zealand Meat Workers and Related Trades Union Inc. “Our History” < http://www.nzmeatworkersunion.co.nz/our_history.html>.

${ }^{303}$ Ibid.
} 
Freezing Workers Award. ${ }^{304}$ In 1971, the New Zealand Meat Workers and Related Trades Union (NZMWU) was registered under the law. ${ }^{305}$ The NZ Meat Workers \& Related Trades Union Inc. is affiliated with the New Zealand Council of Trade Unions. ${ }^{306}$

Dave Eastlake, the General Secretary of the NZ Meat Workers Union was interviewed for this study. Eastlake has been in the meat industry for the past 47 years, starting out as a labourer and union member on the slaughterhouse floor. Eastlake was first appointed as a Meat Workers Union slaughtermen's delegate on the killing chain about 35 years ago and then union President of the Meat Union Sub Branch in Makarewa in 1977. Around 1980, Eastlake became the Makarewa union's Secretary and during this role, became a member of the NZ Meat Workers Union Executive. By the early 1990s, he was elected Vice President of the NZ Meat Workers and then by the late 1990s, became President. In 2002 at the retirement of the then General Secretary, Eastlake was elected unopposed as the NZ Meat Workers' General Secretary, the position that he currently holds. Prior to his involvement in the meat industry, Eastlake was a driver in a major powerhouse production and union member of the Manapouri Combined Workers Union for 18 months while he served as the representative on the union executive. ${ }^{307}$

\section{(j) New Zealand Nurses Organisation}

The New Zealand Nurses Organisation (NZNO) is one of the biggest unions in New Zealand, representing over 42,000 nurses and health workers throughout the country as of 2009. ${ }^{308}$ The NZNO is also one of New Zealand's oldest unions; the union's activities began in 1905 with a group of nurses collectivising to create the Wellington Private Nurses Association. ${ }^{309}$ By 1909, similar groups began popping up throughout the

\footnotetext{
304 Ibid.

305 Ibid.

${ }^{306}$ New Zealand Council of Trade Unions, above n 259.

${ }^{307}$ Interview with Dave Eastlake, NZ Meat Workers Union General Secretary (Julie Polakoski, 21 September 2010) transcript held by author.

${ }^{308}$ New Zealand Nurses Organisation “About Us” <http://www.nzno.org.nz/about_us; see also Department of Labour, above $n$ 226>.

${ }^{309}$ New Zealand Nurses Organisation “History” About Us <http://www.nzno.org.nz/about_us/history>.
} 
country. ${ }^{310}$ The government first recognized the Private Nurses Association in 1969 as the negotiating body for members' wages and conditions of employment in public hospitals. $^{311}$

As the name of the organisation indicates, the membership of the NZNO consists of nurses of many varieties, including midwives, students, kaimahi hauora, health care workers and allied health professionals. ${ }^{312}$ In addition to nurses, the NZNO is also open to people involved in other health professions. ${ }^{313}$ NZNO is affiliated with the New Zealand Council of Trade Unions. ${ }^{314}$

Three union representatives from the NZNO participated in this study, but all wished to withhold their names and titles for confidentiality purposes.

(k) The New Zealand Council of Trade Unions

The New Zealand Council of Trade Unions (CTU) is a national trade union centre. All of the unions participating in this study are affiliated with this organisation. ${ }^{315}$ Today, 350,000 New Zealand union members and 40 affiliate unions make up the CTU. ${ }^{316}$ CTU President Helen Kelly was interviewed for this study.

\section{Employer Participants}

The employer counterparts for these unions were interviewed, but due to privacy concerns, many wished to remain anonymous. For confidentiality purposes, other names will be used in this study when referring to these employers. The employers participating in this study are:

\footnotetext{
${ }^{310}$ Ibid.

311 Ibid.

312 New Zealand Nurses Organisation “Welcome, Haere Mai” <http://www.nzno.org.nz/>.

${ }^{313}$ New Zealand Nurses Organisation "Membership of NZNO” <http://www.nzno.org.nz/membership>.

314 New Zealand Council of Trade Unions, above n 259.

315 Ibid.

${ }^{316}$ New Zealand Council of Trade Unions “About Us” < http://union.org.nz/about>.
} 


\section{(a) Finance Employer}

A financial institution with staff members organised by FinSec was interviewed for this study. This employer is one of New Zealand's biggest companies based on profit, providing several thousands of jobs throughout the country.

\section{(b) District Health Boards New Zealand}

District Health Boards (DHBs) are responsible for providing health and disability services in their district. Currently, there are 21 DHBs throughout New Zealand that have been in place since 2001 when the New Zealand Public Health and Disability Act was enacted. ${ }^{317}$ About 70 per cent of the workforce is unionized in health. ${ }^{318}$

The District Health Board New Zealand (DHBNZ) is the representative body for all the DHBs in New Zealand. Employee Relations Specialist Kevin McFadgen was interviewed for this study. He has worked in this capacity at the DHBNZ for around three and a half years now, and has worked in both the private and public sectors. ${ }^{319}$

\section{(c) Government Agency Employer}

A public sector government agency organised by the PSA was interviewed for this study. 60 per cent of this employer's workforce belongs to the PSA, and according to this employer, the unionisation rates have always been considerably high in this worksite. Government Agency Employer stated that its workforce has traditionally been “reasonably unionised” for quite some time.

\footnotetext{
${ }^{317}$ District Health Boards New Zealand “About DHBNZ” $<$ http://www.dhbnz.org.nz/Site/DHBNZ/Default.aspx>.

${ }^{318}$ Interview with Kevin McFadgen, DHBNZ Employee Relations Specialist (Julie Polakoski, 3 August 2010) transcript held by author.

319 Ibid.
} 
(d) Merchandise Employer

An employer in the business of selling merchandise with members of its staff organised by just the NDU was interviewed for this study. According to this employer, about 18 per cent of its workforce belongs to the union, and that is a percentage that has grown in the last three to four years. The employer attributes this growth to the fact that the size of the employer has grown over the past three to four years from employing around 800 people to about 3,000 now.

(e) Hospitality Employer

An employer in the hospitality business with members of its staff sparsely unionised was interviewed for this study.

(f) New Zealand Bus

New Zealand Bus is the largest bus operator in New Zealand, providing services in several areas throughout the country. This employer has a very high unionisation rate in its worksite with nine collective agreements in place with multiple unions. ${ }^{320}$

Zane Fulljames, Chief Operating Officer of NZ Bus, was interviewed for this study regarding his relations with the Wellington drivers. GO Wellington has a fleet of 223 buses in operation, with approximately 290 drivers and other staff providing services to around 20 million people a year. ${ }^{321}$

Fulljames was overseas for several years working in various employment environments before coming back to New Zealand in 2008 to work for NZ Bus after the ERA had been enacted. The bussing industry in New Zealand has transitioned from being publicly owned to privately-owned, experiencing a change in ownership a few times

\footnotetext{
${ }^{320}$ Interview with Zane Fulljames, Chief Operating Officer of NZ Bus (Julie Polakoski, 5 August 2010) transcript held by author.

${ }^{321}$ NZ Bus “Who Are We?” About Us < http://www.nzbus.co.nz/who-are-we.php>.
} 
since the initial sale. NZ Bus purchased the bus industry from the previous private sector owner in 2008. Fulljames said that NZ Bus inherited a lot of difficult legacy problems from previous owners' anti-union behaviours. ${ }^{322}$

(g) Meat Industry Employer

A business in the meat industry was interviewed for this study. This employer is unionised by the Meatworkers Union.

(h) Business New Zealand

Business New Zealand is the biggest business advocacy group in New Zealand, claiming that they are "the voice of business."

Paul Mackay, manager of employment relations policy of Business New Zealand was interviewed for this study. MacKay started his career working in the manufacturing sector for many years, and in other industries. ${ }^{324}$ Another representative of Business New Zealand who wished to remain anonymous for this study was also interviewed.

\section{Government}

Neutral government services provided for labour were interviewed or contributed to this study in some capacity.

(a) New Zealand Department of Labour Mediation Service

A representative from the New Zealand Department of Labour Mediation Service contributed to this study.

\footnotetext{
${ }^{322}$ Interview with Zane Fulljames, Chief Operating Officer of NZ Bus (Julie Polakoski, 5 August 2010) transcript held by author.

${ }_{323}$ Business New Zealand “About Us” $<$ http://www.businessnz.org.nz/aboutus> .

${ }^{324}$ Interview with Paul MacKay, Manager of Employment Relations Policy of Business New Zealand (Julie Polakoski, 27 September 2010) transcript held by author.
} 
(b) New Zealand Department of Labour

The New Zealand Department of Labour (DoL) also contributed to this study by offering their previous publications and insight from their own research on the topic.

\section{F. Ethical Procedures}

In order to conduct this study in compliance with the ethical standards set forth by the Victoria University of Wellington's Human Ethics Committee, several procedures were in place to preserve the accuracy of the interviewees' comments and confidentiality. Each interview conducted for this study was audio recorded on the author's laptop computer. The recording was in the possession of the author of this study only and locked on the author's computer, with access only permitted by the author. The recording was then transcribed by the author of this study and then sent to the interviewee. The interviewee was given the opportunity to edit the transcript if it was inaccurate. Additionally, if the interviewee wished to add to, edit, or delete any portion of the interview transcript, they were permitted to do so prior to December of 2010 in the concluding month of this study.

The transcripts from the interviews were kept confidential by the author of this study, only being shared with the supervisor and co-supervisor of this study as agreed to be the participants of the study. All transcripts and recordings made for this study will be destroyed within two years of the study being submitted the Victoria University of Wellington Faculty of Law’s LLM program in February of 2011.

In accordance with the requirements as set forth by the Victoria University of Wellington Pipitea's Human Ethics Committee, all of the participants to this study were given information sheets revealing the research goals and purposes of the study and consent forms. The parties were also asked to sign consent forms, which, if signed, meant that the party understood the goals of the study, the procedures in which the study 
was being conducted, and how the party wished to have their comments cited in study. All of the parties that signed the consent forms also agreed that their comments could be used if the study was published in New Zealand or the United States for academic purposes. Additionally, the parties were all given the following choices as to how their comments would be cited in the study

(1) Name, title, and organisation allowed

(2) Name withheld, but title and organisation allowed

(3) Name, title, and organisation withheld with all comments made by the interviewee kept anonymous apart from being identified as either an employer or union

The author maintains all the signed consent forms from the interviewees of this study; these consent forms will remain confidential and locked up in the author's files for two years at which point they will be destroyed.

\section{G. The quantity of interviews conducted for this study}

A total of 24 interviews were conducted for purposes of this study with union staff, human resource managers for major employers in the private and public sectors, employer interest groups, a union interest group, and government officials in the area of labour management. If a union or employer was responsive and easy to contact, then an attempt was made to interview them. Due to the time restraints of this study, additional interviews were not possible.

\section{The Interviews with the Parties to Collective Bargaining}

This section includes the responses volunteered by the participants of this study during their interviews regarding the good faith reforms surrounding collective bargaining under the ERA and subsequent Amendment Act. Not all of the provisions surrounding good faith in collective bargaining were discussed in these interviews and accordingly, are not included in the sections below. The provisions that were not 
discussed during interviews were left out due to time restraints and the limitations of this study.

\section{A. Bargaining Process Agreement (BPA)}

Section 32 of the Employment Relations Act requires that the parties reach a bargaining process agreement (BPA) once bargaining has been initiated. The Act clearly states this requirement as:

[T]he union and the employer must use their best endeavours to enter into an arrangement, as soon as possible after the initiation of bargaining, that sets out a process for conducting the bargaining in an effective and efficient manner.

The reasoning behind this requirement as set forth in sections 31(d) and 32(1)(a) is that BPAs will help the parties bargain in an "orderly", "effective” and "efficient” manner. In promoting structure to the bargaining process, this requirement attempts to facilitate good faith behaviour during collective bargaining.

Employers and unions participating in this study were asked whether or not the requirement to reach a BPA is helpful. Interviewees were also asked to simply give their opinion about the BPA requirement from their experience. The answers to this question highlights the issues that parties are having with this requirement, but also reflects on how this requirement has facilitated the bargaining process, if at all.

\section{BPAs Where the Union and Employer Have a Good Relationship}

Particularly where the union and employer have been able to establish a good working relationship with one another, the BPA requirement has not been particularly useful. Often times, these parties have been bargaining with one another for quite some time and the union has high density at the worksite. In these circumstances, the parties commented that they are used to bargaining with one another and know how to approach the process in an efficient and effective way without this requirement. Notably, when the 
parties have a good relationship with one another, the BPA requirement has not changed how the parties deal with one another at the bargaining table and to some, unnecessarily adds to what is already a lengthy process. Although this was not discussed in further detail, the fact that the union has a high density at these worksites could also reinforce the good working relationship.

For instance, Meat Industry Employer admitted that often the BPA requirement is not complied with because they have such a long history of bargaining with the main union at its workplace that the parties do not want to waste time with technicalities. According to this employer, 97 per cent of its workers belong to a union. ${ }^{325}$ This employer said that they could see how a BPA would be valuable in other industries which the employer and union often face disputes in bargaining; however, because they have had a good relationship with the union for quite some time, the parties prefer to simply "get to working on the issues rather than get too hung up on the processes that are going to follow in that.” He went on to criticise the requirements:

...we have to have an agreement to teach us how we're going to make a cup of tea, whether we're going to turn the spoon to the left or the right. Experienced negotiators, company managers, union reps...it was like playing charades. Ridiculous.

This employer thinks that the good faith requirements could be simplified by eliminating some of the "pedantic bureaucracy" under the law such as the requirement to reach a BPA. ${ }^{326}$

Its union counterpart, the Meatworkers Union, also commented that the BPA requirement has generally not altered how the union operates with employers. This union said that they have a "pretty standard process agreement" in place with its employer counterpart that simply lays out the guidelines for if and when the parties cannot come to an agreement during bargaining to avoid them "getting too rough with each other" by giving opportunities to settle. Yet, this union did not find the BPA requirement as

\footnotetext{
${ }^{325}$ Interview with a meat industry employer (Julie Polakoski, 9 September 2010) transcript held by author.

${ }^{326}$ Ibid.
} 
something that has changed how the parties at the bargaining table deal with one another. $^{327}$

Similarly, Kevin McFadgen of the NZDHB commented that the BPA requirement is not problematic with the NZNO, a union this employer has a good relationship with and also represents a majority of its workers. McFadgen acknowledged that the requirement to reach a BPA before bargaining can commence does result in a lot more paperwork; yet, the NZDHB and the NZNO have overall not had many issues in reaching a collective BPA. Even if it is not included in the BPA, pre-negotiation discussions have been quite valuable for the NZDHB and the NZNO.

...we would just sit down before the bargaining commenced and say what behaviour we'd expect at the bargaining table. Things like - cell phones off, no computers on...that we'll be open and honest with each other, don't swear and what have you - just simple things that ground rules for bargaining were set right from the start. Maybe that's a thing that's come out of good faith bargaining, I don't know. That's something that we decided we should do so everyone is clear as to what the ground rules are. And often we'd get a mediator to come into bargaining as well - they often set ground rules. So that's been helpful. ${ }^{328}$

However, with other unions that the NZDHB claimed they do not have a good relationship, coming to a BPA can be a long, drawn out endeavour. He stated that, “there's been cases in the health industry where it's been two or three months before we got the BPA sorted out. It's ridiculous. We argue back and forth about the various issues in the BPA.” ${ }^{329}$ Ultimately, whether the NZDHB has been able to establish a good relationship with the union determines whether reaching a BPA is a fairly easy process with positive benefits.

NZDHB's union counterpart, the NZNO, maintained a similar opinion regarding the BPA requirement. The NZNO stated that the BPA is something that is fairly easy for the parties to sit down and agree to "fairly quickly." The type of relationship with the employer and whether or not the union has high density in a worksite determines whether

${ }^{327}$ Interview with Dave Eastlake, NZ Meat Workers Union General Secretary (Julie Polakoski, 21 September 2010) transcript held by author.

${ }^{328}$ Interview with Kevin McFadgen, DHBNZ Employee Relations Specialist (Julie Polakoski, 3 August 2010) transcript held by author.

${ }^{329}$ Ibid. 
or not a BPA will be helpful for the NZNO. NZNO representatives added that union density, which often results in a good relationship with the employer, is a factor in determining the value to BPAs. The NZNO has found that when the union has high density at a worksite, they are able to include more in the BPA to prevent any headaches on their part from the employer. ${ }^{330}$

The EPMU also has not had many issues with reaching BPAs when dealing with “good employers.” Paul Tolich added, "I think in most cases, difficult employers are always going to be difficult. But most of the others give it and stick to it.” Tolich also took the position that the type of relationship the union has with the employer will determine whether the BPA will be concluded easily and followed. ${ }^{331}$

In general, in his experience, union organiser with the TEU believes that productive relationships are ultimately determined by the trust and confidence that is built up between the parties through their prior dealings with one another. Organiser added that BPAs are "probably not a bad idea,” but has found the parties to bargaining breach the BPAs or are alleged to have breached them when the relationship is strained. ${ }^{332}$

Business New Zealand manager Paul Mackay shared similar sentiments that the BPA is not necessary. Mackay commented that, from an employer's perspective, it would be helpful to have some of the process elements removed from the current legislation. For instance, MacKay stated that once bargaining has been initiated by a union, it's frustrating for an employer to then have to say, “'Okay fine, when are we going to meet to do the pre-meet?", 333 Then, Mackay claimed, the parties would have to come up with a BPA, which he argued, could also be contentious because the parties would have to argue about every detail including who will pay for morning teas and lunches. Mackay

\footnotetext{
${ }^{330}$ Interview with NZNO officials (Julie Polakoski, 14 June 2010) transcript held by author.

${ }^{331}$ Interview with Paul Tolich, EPMU National Industry Organiser (Julie Polakoski, 16 September 2010) transcript held by author.

${ }^{332}$ Interview with TEU Union Organiser (Julie Polakoski, 17 June 2010) transcript held by author.

${ }^{333}$ Interview with Paul MacKay, Manager of Employment Relations Policy of Business New Zealand (Julie Polakoski, 27 September 2010) transcript held by author.
} 
said that the parties are forced through this process before they can get to bargaining. He added,

The way I've always been used to doing it and people like me have always been used to doing it is to the other side say, 'Okay, we obviously need to bring some delegates. Who and how much time do you think we're going to need? And where's the best place to do it?' And we'd have that sorted out in ten minutes instead of days or weeks sometimes. So those sorts of things are things that we could see improving ultimately the productivity because we take away reasons for unnecessary argument and stay with the basic principle of you don't muck each other about and there are sufficient ways that you can look at the evidence to say, 'You're playing games here.' But that's not good faith. ${ }^{334}$

According to Business New Zealand's employer perspective, collective bargaining would go more smoothly and the process would be expedited if the process requirements were eliminated and the parties could just get to bargaining. ${ }^{335}$

2. BPAs where the parties do not have a good relationship and general problems with the BPA Requirement

Parties that have not been able to establish a good working relationship with one another and often face hostilities throughout bargaining have had different experiences with the BPA requirement. For some, the BPA has been a helpful guide in getting the parties through bargaining breakdowns. For many, however, the BPA requirement has simply added to tensions and the time that could be spent bargaining. The parties have also found BPAs as an opportunity for their bargaining counterpart to further their own bargaining agenda early rather than simply focusing on an efficient process during this time before negotiations have commenced. When this happens, the BPA requirement is not serving the purpose of simply setting forth a process to facilitate bargaining.

Government Agency Employer talked about having a BPA in place in 2007-2008 that, once it was reached, "was never referred to again. It was just in the background." However, last year when bargaining broke down with the PSA and an agreement could not be reached, the BPA “became quite a focus”, and was referred to in order to

\footnotetext{
${ }^{334}$ Ibid.

${ }^{335}$ Ibid.
} 
determine the parties' next steps. The parties did have different interpretations about some of the clauses in the BPA and both sides had included provisions that, in hindsight, they would have preferred to not have in the agreement. However, overall, it was an important document for this employer in dealing with the PSA when bargaining had reached a standstill. ${ }^{336}$

FinSec, unlike its employer counterpart, did not share the same view as its employer counterpart, and added that the union has not had an easy time with reaching bargaining process agreements with employers, including Finance Employer. Campbell stated that seemingly every year, an employer would want to amend the BPA, holding up the actual bargaining process time.

So for example, yesterday we went down to negotiate the **employer name omitted** bargaining process agreement for our negotiations with them in a few weeks. And that was a different approach for us to actually sit down to bargain that; normally it's kind of just done by email or backwards or forwards. But for the last two years, we haven't actually had a signed BPA in that bank.

**Another employer name omitted** is currently put up a bargaining process agreement that says that people not currently covered by the collective agreement can't vote in the ratification procedure, so that excludes people who we may wish to extend coverage for. I mean, you just get crap like this each year; so no, it hasn’t. And often we end up bargaining without signed BPAs. ${ }^{337}$

Campbell commented that, from his perspective with FinSec, it's good that a BPA does not have to be agreed to because they do not want to have to concede to a lot of things in order to just get to bargaining, and the union will not strike over a BPA dispute. Overall, Campbell was unsure as to how much the bargaining process agreement has contributed to good faith. ${ }^{338}$

The NDU has had the same problem as FinSec with employers using the BPA requirement to try and gain a bargaining advantage over the union. NDU General

\footnotetext{
${ }^{336}$ Interview with Government Agency Employer (Julie Polakoski, 14 October 2010) transcript held by author.

${ }^{337}$ Interview with Andrew Campbell, FinSec Campaigns Director (Julie Polakoski 11 June 2010) transcript held by author.

${ }^{338}$ Ibid.
} 
Secretary Robert Reid stated that every year, an employer will try to add something in the BPA that is simply against the union's interests or limiting the union from fully utilising their rights under the law, resulting in the process just getting "bogged down” with extra time consuming conflicts. 339

Overall, Reid also expressed that, in his experience, BPAs have not been effective in ensuring that bargaining will go more smoothly when tensions arise or the parties cannot come to an agreement. The NDU's BPAs with employers lists a lot of procedures that are mostly already stated in the ERA, such as who is going to represent who, what the parties will do if there is an impasse, and who will pay if the parties need to review the company's books during bargaining in order to substantiate an employer's claim as to their financial situation. "Sometimes we actually spend more time actually trying to negotiate how we negotiate than we do in negotiations”, said Reid. Half of the time, Reid added, the parties are unable to agree about what might happen, not necessarily what will happen during negotiations. Reid took the view that, in some ways, he would prefer the law to simply lie out how "unions and employers should negotiate full stop" so they can go forward and do the actual negotiation. ${ }^{340}$

TEU Organiser has also experienced employers who have tried to use the requirement as a means of "defence... another line in which [the employer] could be disagreeable before they got on to being substantively disagreeable.”341

Zane Fulljames with NZ Bus had possibly the worst experiences among all the interviewees of this study with BPAs. He admitted that the intent behind the requirement is “absolutely appropriate”, and it is "really helpful to go into a negotiation and clearly understand from both sides what the process looks and feels like, and what are the

\footnotetext{
${ }^{339}$ Interview with Robert Reid, NDU General Secretary (Julie Polakoski, 15 June 2010) transcript held by author.

340 Ibid.

${ }^{341}$ Interview with TEU Union Organiser (Julie Polakoski, 17 June 2010) transcript held by author.
} 
constraints that each party have.”342 However, the requirement has been a source of conflict with this employer's dealings with the union.

"Example: in 2008 we had industrial action around the bargaining process agreement because we had a different interpretation of a particular element to the union. It didn't go to mediation. It didn't go to the Employment Relations Authority. It just went straight to a strike action.

In fact, we had the same thing in 2010 earlier on this year in Wellington because we were looking to expand as an employer the bargaining process agreement. And we'd actually reached agreement with the union around the framework but because they were fishing for a MECA, there was another employer involved that had a different interpretation of what a BPA should look like. They took industrial action. So the prior two businesses with 500-odd people, we had agreed a bargaining process agreement that we were comfortable with, they were comfortable with. Had another employer not party to our business, had twenty or thirty people being represented. We had 500. They had 20 or 30. That employer put a bargaining process agreement forward that was completely at odds with what the union was seeking...not our issue, but we got dragged into industrial disputes, strike action. ${ }^{343}$

His experience has been that the BPA requirement has led to more industrial unrest than being something that facilitates the bargaining process.

Alistair Duncan with the SFWU finds BPAs useful in determining who will bear certain costs during bargaining, such as travel costs, the costs of food, etc. However, the SFWU has 500 collective agreements to negotiate a year with 23,000 members and a union staff of 60. "Do the math. Every minute of every day spend on the bargaining process agreement is a day not spent [on collective bargaining.]” Duncan took the view that the requirement is not entirely an efficient use of time. ${ }^{344}$

Similar to the tactics union have alleged that employers adopt to frustrate this requirement, Duncan also commented that bargaining process agreements are a good testing ground to see how much the union can get out of an employer during bargaining.

\footnotetext{
${ }^{342}$ Interview with Zane Fulljames, Chief Operating Officer of NZ Bus (Julie Polakoski, 5 August 2010) transcript held by author.

${ }^{343}$ Ibid.

${ }^{344}$ Interview with Alaister Duncan, SFWU Central Region Secretary (Julie Polakoski, 17 September 2010) transcript held by author.
} 
One of the things we do in all our bargaining process agreements now is we put up a claim that any agreement shall include the bargaining fee. There's not an employer I've met who has agreed to it, but it starts that conversation early on. So I suppose it's foreshadowing your tension points...I think the bargaining process agreement is a string to the bow, but I don't think we've thought through quite how to play that bow loudly enough. ${ }^{345}$

Instead of focusing on procedures that may be helpful to follow during bargaining, this union has started to use the requirement to conclude a BPA as an opportunity to kick off the union's agenda early. ${ }^{346}$

\section{Positive Feedback regarding the BPA Requirement}

Some parties have had positive experiences with the BPA requirement, even if their bargaining counterparts did not express similar satisfaction in their interviews. These comments, however, reflect that in some instances, the parties have been able to utilize the BPA requirement to advance efficient and effective bargaining in accordance with the ERA and Code of Good Faith.

Finance Employer commented that, if they are used properly, BPAs are helpful to them at the bargaining table with the union. He added, "If you use them to try and anticipate what issues may come up have essentially a solution already in place, then they're very helpful.” This interviewee had positive experiences with reaching a BPA with FinSec and utilizing one during collective bargaining. ${ }^{347}$

Andrew Casidy, also with FinSec, said that BPAs have been valuable because, despite FinSec having some difficulties with employers in reaching them, they "do impose a set of behaviours on people” that facilitate the bargaining process. ${ }^{348}$

\footnotetext{
345 Ibid.

346 Ibid.

${ }^{347}$ Interview with Finance Employer (Julie Polakoski, 27 July 2010) transcript held by author.

${ }^{348}$ Interview with Andrew Casidy, FinSec General Secretary (Julie Polakoski 28 June 2010) transcript held by author.
} 
Merchandise Employer has found, in their experience, BPAs to be helpful in their bargaining relations with the NDU. This employer appreciated the ground rules established by BPAs and found BPAs to be "quite useful internally in terms of communicating about business, with the process of bargaining, the timelines in bargaining." For this employer, BPAs have helped "with communication and moving information out around our network." With 44 sites around the country, the BPA has helped this employer maintain "direct local relationships with union members, union delegates, and local organizers" by keeping all parties involved better informed to work together more effectively. ${ }^{349}$

\section{Conclusion Regarding the BPA Requirement}

Out of the 14 interviewees who commented on the BPA requirement, only three found it to be useful and a worthwhile contribution to the bargaining process. Parties who already know how to bargain effectively and efficiently from their prior dealings with one another did not find this requirement to be helpful. Parties with strained relationships commented that this requirement only added to rising tension. The most disturbing piece of information that surfaced from these interviews was that this requirement to reach a BPA has, in some ways, given difficult employers that are openly anti-union the opportunity to try to draw out the process and attempt to even limit the union's rights and remedies under the Act.

Three interviewees commented that the BPA requirement has helped facilitate bargaining for them when the BPA is used correctly in accordance with the Act. Others commented that the idea of having a BPA is good in theory, but in practice has not provided positive results.

Where the parties did not have a good relationship, the BPA typically did not help build a good relationship; rather, the BPA requirement often added to a dispute rather

\footnotetext{
${ }^{349}$ Interview with Merchandise Employer (Julie Polakoski, 29 September 2010) transcript held by author.
} 
than helped calm the parties tensions. Additionally, where the parties did have a good relationship, the BPA requirement seemed to only unnecessarily prolong what would have been an already efficient and effective bargaining process.

The parties who found the BPA requirement valuable to the bargaining process did not share similar views as their bargaining counterpart. This discrepancy in opinions indicates that many issues may still remain despite unilateral positive responses.

\section{B. Collective Bargaining Process}

The parties to this study were asked whether or not good faith has helped, hurt, or done nothing to improve the bargaining process. While none of the interviewees believed that good faith should be abolished under New Zealand's employment laws, many of the interviewees expressed disappointment with the duty of good faith in collective bargaining.

Notably, when asked whether or not good faith has done anything to improve the collective bargaining process, the parties did not entirely distinguish between the process of good faith bargaining and the outcomes of good faith bargaining in expressing their satisfaction with the legal reforms. Many interviewees were disappointed with the good faith collective bargaining process’ inability to deliver better collective bargaining outcomes. Because the goal of bargaining in good faith is to reach a collective bargaining agreement, the responses are not broken up in this section of the study between the process and the outcome. Accordingly, the following reveals the parties' opinions of bargaining in good faith and the results from engaging in the good faith bargaining process.

Again, the parties' experiences with the good faith requirements in collective bargaining were often heavily influenced by the type of relationship they have with their respective bargaining counterparts. If the union and employer already had a good relationship, good faith did not change much about the parties’ behaviours during 
collective bargaining. However, where the employer and union had a strained relationship, the good faith requirements sometimes facilitated the process; when the relationship was really strained, the good faith requirements were used as a tool for more dispute rather than tools for easing tensions around bargaining.

\section{Opinions of unions regarding the duty of good faith in collective bargaining}

Andrew Casidy with FinSec commented that the ERA did modify behaviour around bargaining and "that has certainly helped and smoothed at times the various processes" that the union and the employer go through during bargaining. However, overall, to FinSec,

"the ERA itself has absolutely not achieved its aims which were to essentially try and rebalance some of the inequities of power between the parties in bargaining."

While the good faith provisions in the ERA have been an improvement for the processes used around the table for FinSec, the outcomes during bargaining have not changed; in fact, Casidy commented, "from that point of view, I would suggest that it's been a spectacular failure.” Casidy emphasized much disappointment with the ERA's inability to even out the bargaining playing field in accordance with one of the Act's stated purposes. ${ }^{350}$

Casidy's co-worker at FinSec, Andrew Campbell, also has not seen any real impacts of good faith in collective bargaining. In fact, overall, he stated that FinSec's experience with good faith in collective bargaining has been "pretty negative.” According to Campbell, good faith has resulted in an improvement in the language that is used between the parties, but the union has not overall relied on good faith to achieve improvements on certain issues. Campbell commented,

I think a culture has developed in New Zealand where the parties and advocates at the table are quite expert in talking the language of good faith, using it in a threatening way perhaps in emails....but are we really much more active and constructive? No.

\footnotetext{
${ }^{350}$ Interview with Andrew Casidy, FinSec General Secretary (Julie Polakoski 28 June 2010) transcript held by author.
} 
He stated that the union and the employer are aware of good faith and the current legislation is an improvement from the ECA; however, he believes reform is necessary to make good faith “a much more enforceable requirement” rather than just changing superficially the words used during bargaining. ${ }^{351}$

The National Distribution Union’s (NDU) General Secretary Robert Reid also noted, "the words good faith appear in almost every single piece of correspondence now between unions and employers." When the NDU sends what they call a "shitty letter" to one of the employers they bargain with, "telling them what they have to do", the NDU will also "demand that they do this in good faith." For the NDU, in workplaces where they have been bargaining for a while, the bargaining is reasonable. "Whether it's because of good faith? I'm not sure because even in the prime of the Employment Contracts Act time and the Labour Relations Act, we didn't have good faith mentioned per say, but we still bargained”, stated Reid. ${ }^{352}$

To Paul Tolich with the EPMU, the good faith bargaining process requirements under the ERA are an improvement from the days of the ECA in which employers could engage in "complete fabrication” at the bargaining table, "a lot of deception and a lot of straight out lying and mystification.” Tolich remarked that the ERA has "improved the climate” to require more transparent relations between unions and employers during bargaining. However, even so, although it might not be as widespread as it was during the ECA, the EPMU still encounters deceptive behaviour on the behalf of employers even under the ERA; good faith has not been strong enough to eliminate the behaviour in its entirety. ${ }^{353}$

PSA organizer Jim Jones appreciates that "good faith provided access...to bargaining and bargaining outcomes” that might not have been possible in workplaces

\footnotetext{
${ }^{351}$ Interview with Andrew Campbell, FinSec Campaigns Director (Julie Polakoski 11 June 2010) transcript held by author.

${ }^{352}$ Interview with Robert Reid, NDU General Secretary (Julie Polakoski, 15 June 2010) transcript held by author.

${ }^{353}$ Interview with Paul Tolich, EPMU National Industry Organiser (Julie Polakoski, 16 September 2010) transcript held by author.
} 
where union density might not have been high enough to achieve enough "organising power" to conclude a "reasonable agreement without good faith." There is a "greater recognition” of bargaining as a right, and protecting the processes around collective bargaining under the law has encouraged more collective bargaining. However, in his experience, good faith does not "guarantee that you'll end up with a deal" at the end of the day. Jones' comments reflected an appreciation of the ERA at least protecting the collective bargaining process as a right in New Zealand. ${ }^{354}$

Omar Hamed with Unite believes that the good faith provisions have not created the "necessary foundation” to establish good faith relationships, and simply have not “done enough" to protect collective bargaining. "It's not the greatest law in the world", he stated. In his experience, good faith has only been valuable during collective bargaining when dealing with a good employer. When an employer is reluctant to engage in bargaining and instead engages in anti-union tactics, good faith has not done much to improve collective bargaining. ${ }^{355}$

The Service and Food Workers Union’s (SFWU) Central Region Secretary Alastair Duncan compared the duty of good faith in collective bargaining with fast food advertisements.

The advertisement looked great. You might have bought the product. It's perhaps like driving past yet another advertisement for McDonald's, which we know, is bad for us, but the ad looks so appealing it can't be that bad.

Duncan made it clear that the good faith requirements only made "bad employers" act in good faith on the superficially. Duncan has found that the practice of good faith has turned out completely different to the theory behind good faith. "The Employment Relations Act is the Employment Contracts Act with soft edges.” The process requirements of the act have not delivered fairer outcomes for his union in collective bargaining. Some of the union's relationships have changed with employers and some have not, added Duncan:

\footnotetext{
${ }^{354}$ Interview with Jim Jones, PSA Organiser (Julie Polakoski, 20 July 2010) transcript held by author.

${ }^{355}$ Interview with Omar Hamed, Unite Organiser (Julie Polakoski 19 July 2010) transcript held by author.
} 
...the bastard employers are still bastards but they're operating in good faith. The difficult employers are perhaps slightly less difficult and the employers who we had reasonable relationships with the reasonable relationship is maintained.

Duncan had similar experiences to his union colleagues in that the ERA has simply changed the language used around the bargaining table, but has not provided substantively different outcomes for bargaining. ${ }^{356}$

TEU Organiser added that the good faith requirements have not had "a huge effect” on collective bargaining. Many of the good faith requirements under the ERA are still vague to his union and how they are to be applied in collective bargaining. To Organiser, good faith has not been strong enough to make any vast improvements for collective bargaining in New Zealand, and in that sense, has been a disappointment for the labour movement. ${ }^{357}$

The NZNO appreciates that the duty of good faith in collective bargaining has opened up "possibilities for engagement” that did not otherwise exist during the days of the ECA when employers could avoid the union if they were not interested in talking specifically about bargaining. During the days of the ECA, the NZNO, like all unions in New Zealand, was treated as a bargaining agent. As such, the NZNO experienced that reluctant employers could easily avoid bargaining with the union. However, the NZNO stated that the ERA changed this for them for the better; the Act

provided a basis and a mechanism by which employer can be held to it to account for bargaining processes which previously would have been null under the Employment Contracts Act.

In their experience under the ERA, employers will now go through the dispute forums if they don't comply, and will now participate in a "genuine bargaining process" with the union. For the NZNO, the obligation for employers to bargain with the union as opposed to simply treating them like an agent that did not have to be recognized was the biggest improvement for them. ${ }^{358}$

\footnotetext{
${ }^{356}$ Interview with Alaister Duncan, SFWU Central Region Secretary (Julie Polakoski, 17 September 2010) transcript held by author.

${ }^{357}$ Interview with TEU Union Organiser (Julie Polakoski, 17 June 2010) transcript held by author.

${ }^{358}$ Interview with NZNO officials (Julie Polakoski, 14 June 2010) transcript held by author.
} 
It is important to note that the NZNO has noticed that the public sector health employers have distinctively embraced good faith more in collective bargaining than private sector employers; in the public sector, the NZNO has high density and has already established a good relationship with the employer. Additionally, the NZNO has been able to achieve a MECA in the public sector because of the good faith reforms in collective bargaining. However, in the private sector where the union has low density and has not been able to establish a good relationship with the employer, the duty of good faith in collective bargaining has been "really gutless.” Employers in the private sector still commonly act in bad faith during bargaining towards the NZNO and the laws in place have not been strong enough to prevent that type of behaviour. ${ }^{359}$

The Meatworkers Union also agreed that the union's behaviour and the employer's behaviour haven't changed, even with regards to a particularly bad employer that the union has been struggling with in recent years. The only difference now is that the "bad employer" will remind the union to behave in good faith and vice-versa; however, the parties’ actual behaviour hasn't changed. ${ }^{360}$

\section{Employer opinions about the impacts of good faith in collective bargaining}

Employers expressed similar sentiments regarding the impacts of good faith in the ERA from their union counterparts. Employers’ opinions also recognised the insufficiencies of good faith as being a focus for changing party’s behaviours during collective bargaining.

Kevin McFadgen of the NZDHB commented that the ERA did not really change much for them in their dealings with their union counterparts. With regards to their dealings with the NZNO, a union holding high density at its worksite and with whom the employer has a good relationship, McFadgen stated,

\footnotetext{
359 Ibid.

${ }^{360}$ Interview with Dave Eastlake, NZ Meat Workers Union General Secretary (Julie Polakoski, 21 September 2010) transcript held by author.
} 
“I don’t think the good faith legislation has actually changed our behaviour with them. I don't think they've had to change their behaviour either....I think obviously we became more aware of what your obligations were under the Act, but other than that, I don't think it changed the dynamics too much.”

According to McFadgen, the NZNO and itself have always engaged with one another in good faith, and are just more aware of the requirements now. ${ }^{361}$

From the perspective of Finance Employer, it has always had "a pretty good relationship” with FinSec, and “the good faith provisions in a lot of respects didn't make too much difference.” Again, according to Finance Employer, the good faith provisions have made the parties more aware of their obligations at the bargaining table, but overall did not make any big impacts on their behaviour. However, this employer went to add that while the outcomes of bargaining might not be different at the end of the day under the ERA, "the relationship in terms of what happened to get there" has certainly improved. In comparison with the "bad old days" of work stoppages, industrial action, and unrest, the duty of good faith in collective bargaining is a vast improvement because, in his opinion, the same outcome is achieved as back then except that now, the same outcome is achieved with less pain. This employer shared the view of its union counterparts: the good faith requirements have improved the process of collective bargaining, but the outcome (the collective employment agreement and collective bargaining coverage) has not changed. ${ }^{362}$

Government Agency Employer has had mixed experiences with the duty of good faith in collective bargaining. For this employer, “...the good faith provisions have been a blessing in some cases and terribly frustrating in other ways." Its experience with the ERA has been that good faith is "something that the employer is bound by but not the union necessarily.” For them, good faith has led to more industrial unrest and disputes than the days of the ECA. ${ }^{363}$

\footnotetext{
${ }^{361}$ Interview with Kevin McFadgen, DHBNZ Employee Relations Specialist (Julie Polakoski, 3 August 2010) transcript held by author.

${ }^{362}$ Interview with Finance Employer (Julie Polakoski, 27 July 2010) transcript held by author.

${ }^{363}$ Interview with Government Agency Employer (Julie Polakoski, 14 October 2010) transcript held by author.
} 
Although he agreed that the intention to have good faith "makes good sense" in the law, Zane Fulljames with NZ Bus reported a lot of negative experiences with good faith. When the parties at the bargaining table do not have a good relationship with one another, it has been his experience that good faith is rarely used as a tool to help ease tensions and resume productive bargaining. This employer stated that good faith has, in some instances, been used as a "lever to create industrial conflict" and historically in some environments, it’s been a device "to kick off a dispute.” Good faith has been "real easy to throw it around" as a weapon when the parties are not in agreement, not a source for resolution. Additionally, "the application of the duty of good faith" has leaned more towards misuse rather than the sincere notion of the terms good faith in his dealings with unions and other employers. He commented, "Example: it constantly gets bandied around when negotiations become particularly difficult that you're not acting in good faith.” For this employer, good faith has been a tool to create disputes rather than ease relations between the union and the employer. ${ }^{364}$

Meat Industry Employer held the opinion that its relations with the Meatworkers Union have not changed since the enactment of the ERA. According to Meat Industry Employer,

“We didn’t notice a great deal of changes. We had always conducted ourselves in that way anyways. Even when the Contract Act was in New Zealand which people try to paint when they're recounting history as some sort of great liberalization where employers could do out and do whatever they chose when they chose to whom they chose, we never did that. We continued to deal with unions and maintain collective agreements right throughout, so for us it wasn't such a big deal.”

Again, this employer has been able to establish a good working relationship with the Meatworkers Union during the ECA and maintains a very high percentage of unionised workers at its worksite. ${ }^{365}$

\footnotetext{
${ }^{364}$ Interview with Zane Fulljames, Chief Operating Officer of NZ Bus (Julie Polakoski, 5 August 2010) transcript held by author.

${ }^{365}$ Interview with a Meat Industry Employer (Julie Polakoski, 9 September 2010) transcript held by author.
} 
However, with regards to unions that the meat industry employer does not have a good relationship with, good faith has been of some assistance. In this employer's opinion, he thinks that some of the "union extremists who thought this was going to be a great tool that employers were going to get beaten up with” have now learned that good faith is a "two-way street." Although he has found that some of that "nasty unionist stuff” still sometimes happens in some cases, there are rules in place guiding how they must conduct their behaviour, and in his opinion, that was a positive change for the union movement. $^{366}$

\section{Conclusion Regarding Good Faith in Collective Bargaining}

No one to this study said that good faith should be abolished in New Zealand's employment laws, nor is it likely that any of the interviewees would want good faith abolished. However, most of the participants to this study did not believe that good faith made a major impact on the parties’ behaviours during bargaining.

The majority of interviewees conceded that good faith has benefitted the bargaining process in some ways. However, in terms of overall positive results from these bargaining processes, the parties expressed much disappointment in terms of what good faith has delivered. Additionally, most interviewees did not believe that good faith substantively altered the behaviours of parties during collective bargaining. In this way, the results from the interviewees reflect that good faith is a process-oriented requirement.

\section{Information Requests and Disclosures during Bargaining}

The Employment Relations Act requires the parties to provide information to substantiate a claim made at the bargaining table. In other words, good faith as required under the ERA requires bargaining to be as informed as possible so that the positions of the parties are clear and understood.

${ }^{366}$ Ibid. 
The participants to this study were asked whether there has been more of a flow of information during bargaining since the enactment of the ERA. Opinions were solicited regarding whether or not the parties to collective bargaining felt that they were kept better informed of their bargaining counterpart's position.

Overall, the participants to this study provided the most positive feedback regarding this requirement under the ERA. None of the interviewees took the position that this requirement is not helpful during bargaining. Although some interviewees (mostly unions) have had issues with their bargaining counterparts complying with information requests and substantiating their claims in negotiations, all interviewees took the position that this requirement does facilitate bargaining. Overall, a better flow of information during the bargaining process has helped most interviewees in their dealings with their collective bargaining counterparts.

\section{Employers' opinions regarding information requests and the flow of information during bargaining}

Meat Industry Employer has experienced a good flow of information from both sides during bargaining to help with the process. This employer has not, in its experience, had negotiations break down from the union rejecting a proposal without putting reasons forward for that rejection. Meat Industry Employer commented that the union supports its proposals with arguments behind those proposals. ${ }^{367}$

However, Meat Industry Employer took the position that they have had an open, communicative relationship with the union since the ECA. For this employer, having that kind of transparent and honest relationship was something that has always been part of their strategy; thus, the amendment to provide information to back up claims made at the bargaining table did not, in their opinions, change their behaviour. ${ }^{368}$

\footnotetext{
${ }^{367}$ Interview with a Meat Industry employer (Julie Polakoski, 9 September 2010) transcript held by author. ${ }^{368}$ Interview with a Meat Industry employer (Julie Polakoski, 9 September 2010) transcript held by author.
} 
Merchandise Employer commented that since the enactment of the ERA, there has been more of a flow of information from them to the union during bargaining. He added that there is more disclosure on behalf of the employer to the union of

business objectives and strategies in ways that in our mind, the employer's mind, are designed to help the union understand the issues that the company has for it, and some of the key objectives to...engage the union to...seek support where appropriate.

The good faith requirements have led this employer to provide information to give a framework for their claims and counterclaims, in addition to the rationale behind their acceptance or rejection of a claim at the bargaining table. ${ }^{369}$

Kevin McFadgen of the NZDHB stated that interest-based bargaining has been the most helpful approach for them to take with the union during bargaining, which is perhaps something that this provision encourages. Interest-based bargaining involves the parties sitting down and discussing the issues, provide all necessary information for the other side to understand your position in the issue, and then brainstorm potential solutions. Instead of a party putting a claim on the table without any reasoning behind it, the parties will come in and state what the think and try to understand what the issues are. McFadgen stated that, "It's asking questions rather than thumping on the table and just saying, 'Why don't you give it to us?!'” Although this process might be more time consuming, the result has been more positive because the parties are more confident that they have reached the right outcome. McFadgen remarked that it will provide the union with information about the company's financial situation, helping the union to understand what the employer is capable of offering. Health Employer has found that the flow of information has kept the parties more informed at the bargaining table of what the problem is by supporting your position and claim with actual facts. ${ }^{370}$

Finance Sector Employer held the opinion that, while the outcome of bargaining may not be different, process requirements such as these to be responsive to information

\footnotetext{
${ }^{369}$ Interview with Merchandise Employer (Julie Polakoski, 29 September 2010) transcript held by author.

${ }^{370}$ Interview with Kevin McFadgen, DHBNZ Employee Relations Specialist (Julie Polakoski, 3 August 2010) transcript held by author.
} 
requests and disclosing information to substantiate a claim during bargaining have helped bargaining relationships. When making a claim to the employer, the union will say that they are making a claim because that is what their members have expressed what they want. However, the employer stated that in those situations, they will remind the union that the ERA requires more than that, and then the union will remind the employer of the same as well. Finance Sector Employer held the opinion that the requirements under the Act to be "constructive and responsive" have been useful every so often. ${ }^{371}$

Government Agency Employer also claimed that it has always been its position as an employer to be open and communicative with their union counterparts, providing information to the union to substantiate their position in bargaining. Yet, this employer has not always found this type of behaviour to be reciprocated by the union. Government Agency Employer stated that the union they deal with still makes claims during bargaining without providing reasoning behind their claims. This employer added that their conversation with the union is fairly short:

...the only response we'd get is, 'That's unacceptable to our members.' You know, 'It doesn't fit with our mandate so therefore, we understand that you haven't got the money, but our members won't accept anything that's less than what we're asking for.' So therefore, that's the end of the argument for us.

Although this employer added that they are trying to get the discussion with the union moving along to alternatives or compromises, they have not gotten very far because the union has refused to make any concessions about their mandate. Government Agency Employer took the position that the requirement to provide information to substantiate a claim or position during bargaining should be strengthened. ${ }^{372}$

\footnotetext{
${ }^{371}$ Interview with Finance Employer (Julie Polakoski, 27 July 2010) transcript held by author.

${ }^{372}$ Interview with Government Agency Employer (Julie Polakoski, 14 October 2010) transcript held by author.
} 


\section{Unions' opinions regarding information requests and the flow of information} during bargaining

In the EPMU's experience, having enough information from the employer to substantiate a claim usually involves the union looking at the books. Sometimes they are able to get employers to show them enough financial information so the union can understand that the employer cannot afford to pay, and other times it has been likely that the union was not shown everything. Using a formal, professional accountant has been helpful for the union to fully understand an employer's financial position during bargaining. ${ }^{373}$

FinSec has had difficulties with employers providing sufficient information at the bargaining table. Last year, one employer flat out refused to provide the union with a lot of information that they requested in good faith, and even a week before the interview for this study, another employer refused to "swap claims" until the bargaining process agreement had been signed. FinSec has also had issues since the good faith amendments have been passed with employers providing information that is so unorganised in such large numbers that it is effectively unusable. The union has also had problems with employers flat out refusing information requests regarding information related to bargaining such as job description information and the cost of percentage increases in wages. ${ }^{374}$

The NZNO has said that they have been able to work with their employers constructively on a whole range of issues, and have seen variable success. It has been the union's approach with employers at the bargaining table to be as open as they can be in a professional manner. Even with the good faith provisions to be transparent and communicative, some employers will still not be completely forthcoming regarding the company's financial status.

\footnotetext{
${ }^{373}$ Interview with Paul Tolich, EPMU National Industry Organiser (Julie Polakoski, 16 September 2010) transcript held by author.

${ }^{374}$ Interview with Andrew Campbell, FinSec Campaigns Director (Julie Polakoski 11 June 2010) transcript held by author.
} 
You ask for financial information and they give you a document with one line on it showing a deficit of three million dollars or something, and you go, 'Well, what about all the other relevant information?' And they say that's all that is relevant.

NZNO has found it helpful to make their requests as specific as possible, commenting that making information requests from employers is almost like cross-examining a witness; being direct, firm, and as detailed as possible has helped in getting employers to provide information to the union during bargaining. ${ }^{375}$

Alistair Duncan from the SFWU was still quite sceptical of the process of issuesbased bargaining. While the parties may seem to be focused on the issues during bargaining, he believes it to be "a veneer. It’s a gloss.” he commented. To Duncan, it might be a means to an end, "but unless we're focused on that end, then it's a distraction.” Duncan emphasized that during bargaining, the employer and the union need to remain focused on the end point and not get too caught up on the process there. ${ }^{376}$

PSA union organizer Jim Jones also admitted that good faith has been used at times by employers as a "tactic" to frustrate the bargaining process. He stated that some employers have demanded information from the union, which would reveal their bargaining strategies if only to make the process more difficult, claiming that they were entitled to such information under the good faith provisions. At times, good faith has been used at the bargaining table to "sidetrack" the parties from the "core objectives" of the bargaining process and ultimately, the objectives of the ERA. ${ }^{377}$

3. Conclusion regarding the interviewees' experience with information requests and disclosures made during bargaining

100 per cent of the interviewees who commented on the requirement to be responsive to information requests and communicative about one's claims during bargaining took the position that it is a valuable requirement. Of the five unions who

\footnotetext{
${ }^{375}$ Interview with NZNO officials (Julie Polakoski, 14 June 2010) transcript held by author.

${ }^{376}$ Interview with Alaister Duncan, SFWU Central Region Secretary (Julie Polakoski, 17 September 2010) transcript held by author.

${ }^{377}$ Interview with Jim Jones, PSA Organiser (Julie Polakoski, 20 July 2010) transcript held by author.
} 
commented on this provision, all of them cited issues with employers' compliance. However, only one out of the five employers who commented on this requirement expressed that its union counterpart was not compliant.

The union respondents have found employers to not always be as forthcoming with regards to information requests. This is unsurprising given the fact that employers would generally need to provide information regarding the company's financial situation and other potentially sensitive information that the union would not need to provide during bargaining. However, when a company is able to make a union fully aware of what it is capable of offering financially to union members, the union is better able to make more reasonable claims in negotiations. Accordingly, where this requirement is complied with, the collective bargaining process has been more effective for parties.

\section{Undermining Bargaining}

\section{Introduction}

It is a breach of the duty of good faith for a party to engage in behaviour that undermines the bargaining process. The ERA and the Code of Good Faith enumerate behaviour that is considered to be undermining in breach of the duty of good faith. The following discussion highlights the behaviour unions and employers have experienced that would be considered undermining of the collective bargaining process in breach of the duty of good faith.

Section 32(1) and (5) indicate that the prohibitions set forth in sections 4 and 32 of the Employment Relations Act with regards to undermining bargaining are not exhaustive. Accordingly, the following discussion is not a complete list as to how the bargaining process has been undermined or the bargaining agents have been undermined according to the interviewees of this study. This list, however, reflects the issues that the participants to this study were most vocal about during their interviews with regards to undermining bargaining. 


\section{Direct Communications with Employees During Bargaining, Keeping Employees} Informed about Bargaining Progress and Attempts to Induce Employees

The interviewees were asked which area of the law they would like to see reformed or changed, and employers were most vocal about the need to reform the law regarding communications made during bargaining. Because most unions did not respond to this question the same way, some union interviewees were asked if they have had problems with communications made during bargaining.

These three areas of the law involving good faith are combined in this section because the interviewees' responses were often intertwined with the one another. Communications amounting to direct or indirect bargaining must be directed to the bargaining representative only. ${ }^{378}$ The Code of Good Faith also provides that:

The parties must recognise the role and authority of any person chosen by each to be its representative or advocate. ${ }^{379}$

Direct communications are permitted in good faith as long as they are not:

- Directly or indirectly misleading or deceptive or likely to be so to the receiving party of the communication ${ }^{380}$

- $\quad$ Amounting to direct or indirect bargaining ${ }^{381}$

- $\quad$ Undermining the bargaining process itself ${ }^{382}$

- $\quad$ Undermining the authority of the bargaining representatives ${ }^{383}$

- Inaccurately informing constituents or failing to inform constituents of the progress and offers being made during bargaining. ${ }^{384}$

Section 4(3) states that a party to an employment relationship is permitted to communicate to another person "a statement of fact or of opinion reasonably held about an employer's business or union's affairs.” However, at no point is an employer permitted to advise or do anything with the intention of inducing an employee not to be

\footnotetext{
${ }^{378}$ Employment Relations Act 2000, s 32(1)(d).

${ }^{379}$ Code of Good Faith in Collective Bargaining, s 3.7.

${ }^{380}$ Employment Relations Amendment Act 2004, s 4(1).

${ }^{381}$ Employment Relations Act 2000, s 32(1).

382 Ibid.

383 Ibid.

${ }^{384}$ Employment Relations Amendment Act 2004, s 4.
} 
involved in bargaining for a collective agreement or not be covered by a collective agreement. ${ }^{385}$ Additionally, bargaining representatives are expected to accurately keep their constituents apprised of the developments made during bargaining and advance the interests of their constituents at the bargaining table. ${ }^{386}$

The following responses highlight that this is a somewhat contentious area for unions and employers, particularly because the parties seem unclear as to what is permitted. Employers were more vocal in expressing a need for reform regarding communications made during bargaining than unions.

(a) Employers' experiences with employee communications made during bargaining

Business New Zealand held the view that many employers are under the false impression that they cannot speak to any of their employees during bargaining when the courts have made it clear that communications are permitted during bargaining as long as those communications do not "demean or diminish or undermine the role of the union as the agent of the employees." Business New Zealand recognized that it is permissible for employers to make direct statements to its employees such as, "'We met with the union today and they asked for 10 per cent and we offered them three.’” Business New Zealand understands that factual communications are permitted, but the employer is not allowed to say anything to persuade an employee regarding whether or not to join the union. However, Business New Zealand has found that most employers do not understand this or are simply not able to follow these rules because unions do not understand the law. The following responses from employer interviewees highlight that Business New Zealand was correct in this observation. ${ }^{387}$

Kevin McFadgen of the NZDHB commented that being able to communicate with its staff during negotiations is one area of the law that needs to be clarified or reformed.

\footnotetext{
${ }^{385}$ Employment Relations Act 2000, s 4(6).

${ }^{386}$ Employment Relations Act 2000, s 4(2).

${ }^{387}$ Interview with Paul MacKay, Manager of Employment Relations Policy of Business New Zealand (Julie Polakoski, 27 September 2010) transcript held by author.
} 
This employer stated that as the law currently stands, employers are not permitted to communicate with its staff regarding negotiations during negotiations. ${ }^{388}$

Merchandise employer stated that it has been its goal as an employer to treat everyone as a team; however, under the law as it currently stands, it is forced to treat its workforce as "two classes of citizens": the unionised employees and the non-unionised employees. Not being able to communicate as well as they could to all of their staff during bargaining has been a "road block" for this employer. This employer had the opinion that not being able to communicate with union members directly during bargaining has negatively impacted the whole philosophy it strives to follow in how it would like to treat and manage its employees. ${ }^{389}$

Government Agency Employer has had "significant problems" with regards to communicating to unionised staff and non-unionized staff during bargaining. According to this employer, their issues with this area of the law started with the union not accurately conveying the employer's offer to its union members during bargaining. Government Agency Employer stated that in one incident with the union, it had made an offer at the bargaining table that the union did not, in its opinion, accurately convey to its members. Instead, the union's bargaining team rejected the offer, which is permitted. However, the employer then attempted to communicate with the union members of its staff the details of the offer that the bargaining team had rejected, and was subsequently taken to the Employment Relations Authority by the union for a breach of good faith. Government Agency Employer expressed that the laws surrounding communications made during bargaining to both union and non-union employees need clarification. In this instance, the employer argued that it was only attempting to convey factual information to members of its staff about bargaining, but even that was not permitted. ${ }^{390}$

\footnotetext{
${ }^{388}$ Interview with Kevin McFadgen, DHBNZ Employee Relations Specialist (Julie Polakoski, 3 August 2010) transcript held by author.

${ }^{389}$ Interview with Merchandise Employer (Julie Polakoski, 29 September 2010) transcript held by author.

${ }^{390}$ Interview with Government Agency Employer (Julie Polakoski, 14 October 2010) transcript held by author.
} 
Zane Fulljames with NZ Bus commented that dealing with the ERA's regulations regarding communications with employees is

like stepping back in time in terms of the construct of the relationship, the construct of the Act...the notion that that you couldn't go out and actually talk to your employees during collective bargaining to explain your position...

Fulljames also believes that the rules around communications lack clarity, and "the ability to interpret them in different ways depending on your needs as an employer, a union, or as an employee” has created significant problems for the employer. For example, in 2008, NZ Bus factually communicated the offer it had made at the collective bargaining table to all employees after the union had incorrectly conveyed the offer. The union then accused the employer of breaching the duty of good faith. ${ }^{391}$

(b) Unions' experiences with employee communications made during bargaining Paul Tolich of the EPMU remarked, "One of the most important provisions in the ECA is that they can't go directly over your head and communicate with members. They can't do it blatantly.” Tolich added that from time to time, the union has problems with employers communicating to its members during bargaining, but overall, the union has not had significant issues with this. Generally, good faith has helped in this regard for the EPMU. $^{392}$

However, Tolich was quite sceptical of employers' claims that unions do not accurately keep their members apprised of the bargaining progress. Tolich holds the opinion that unions cannot to lie to their members about what employers are offering at the bargaining table because it would cause them to lose their credibility and thus, membership numbers.

[Employers] are bullshitting you, basically. They're trying to get it so they can go and attack New Zealand resources to undermine the union's position. The negotiations should be between the parties. The members have given the union

\footnotetext{
${ }^{391}$ Interview with Zane Fulljames, Chief Operating Officer of NZ Bus (Julie Polakoski, 5 August 2010) transcript held by author.

392 Interview with Paul Tolich, EPMU National Industry Organiser (Julie Polakoski, 16 September 2010) transcript held by author.
} 
the power to negotiate. I don't see why the employer needs to deal with them. The members will work out very quickly if they're lied to. You lose face and you lose the respect.

Tolich stated that the claims made by employers is simply an attempt for them to try to get the law reformed so that they can undermine the union more and deter more people from joining. If employers need to say anything to union members, they are able to communicate that message to the union's bargaining team. ${ }^{393}$

Campbell with FinSec stated that employers have pushed the boundaries around communications during bargaining when the Employment Relations Act first came into effect, but in recent years, the union has "tidied that up.” Campbell described the types of problems the union has experienced with employers communicating to union members:

There were occasions where there were offers made to staff who are not members of the union literally weeks prior to collective bargaining which obviously we've felt undermined collective bargaining.

However, when negotiations were not actually taking place, FinSec has had a lot of difficulties with direct communications. FinSec complained of employers making communications before and after collective bargaining that undermined the union's role at the workplace. Direct communication by managers to non-union members of their staff about whether or not they need to be members of the union has become a real problem for FinSec. For instance, one employer told non-union members of its staff that they don't have the obligation to talk to FinSec's organisers at the site, resulting in those employees being too afraid to them speak to the union. Campbell remarked that employers commonly make comments to their members that undermine the union's authority in a workplace and intimidates workers from exercising their rights (their right to organize and join a union). ${ }^{394}$

\footnotetext{
${ }^{393}$ Ibid.

${ }^{394}$ Interview with Andrew Campbell, FinSec Campaigns Director (Julie Polakoski 11 June 2010) transcript held by author.
} 
Andrew Casidy of FinSec has had issues with employers offering union members and non-union members wage increases right before bargaining has commenced. Casidy explained that, four weeks prior to the commencement of bargaining, an employer told all of its employees that it would be offering $\mathrm{x} \%$ wage increase to union members and non union members. Although the union viewed this as undermining the bargaining process in breach of good faith, the employer viewed it as simply meeting its obligations to those members of its staff on individual agreements by giving the wage increase and communicating it to all of its staff. The employer was communicating its offer to the union but also clearly conveying the message that it would offer non-union members the same wage, undermining the relevance of the union with regards to pay. ${ }^{395}$

The NZNO has had experiences with employers trying to communicate what the union and employer are doing in bargaining when the union believes that it is their role to inform their constituents. In these instances, the union has already sent out updates and bulletins to keep its constituents apprised of developments being made in bargaining. Particularly in the private sector, the NZNO has had many problems with employers communicating with its members

...deliberately to undermine... all the time these conscious strategies to make the union look bad or to make the union seem irrelevant or to discourage people from trusting what the union says.

Because of all these problems, the NZNO would prefer that employers not communicate with its members regarding bargaining during negotiations. ${ }^{396}$

In response to hearing that employers find it difficult to communicate to their staff during negotiations, Alastair Duncan remarked,

...they can't in the same way that the union can't turn up to the Board of Directors and say, 'Do you know what your useless managers are up to?' That would actually recognize the sanctity of bargaining.... what happens in bargaining is commercially sensitive and the parties have principals to report to. Now if the thesis is that we can report to reach other's principals, why are we bothering to

\footnotetext{
${ }^{395}$ Interview with Andrew Casidy, FinSec General Secretary (Julie Polakoski 28 June 2010) transcript held by author.

${ }^{396}$ Interview with NZNO officials (Julie Polakoski, 14 June 2010) transcript held by author.
} 
bargain? Why aren’t we simply running a public relations campaign against each other and see who blinks first?

Duncan stated that employers should remember that the good faith relationship also applies to unions and their members. ${ }^{397}$

(c) Conclusion regarding communications made to employees during bargaining

Communications made by an employer to employees during bargaining is an area that has resulted in much dispute between parties. Both sides have conflicting arguments as to how the law should be applied and/or reformed to remedy these problems that still remain under the ERA.

In determining whether the overall objective of the Employment Relations Act has been met, the parties to an employment relationship must at least understand what their rights and duties are under the law. The interviews conducted in this study revealed a general consensus that employers do not all fully understand what is entirely expected of them in terms of good faith with regards to communication during bargaining.

In being a neutral observer of the types of disputes reaching mediation, the representative from the Department of Labour Mediation Service participating in this study also found this to be a problematic area for bargaining parties. "Employers get upset when unions tell their members a completely different story”, he stated. If the union does not accurately convey the employer's position, the employer feels "constrained in terms of how they can respond." The representative sympathised that employers are unable to communicate to the same extent as unions during negotiations regarding each other's positions to the workforce. ${ }^{398}$

Of all the good faith requirements applying to collective bargaining set forth by the ERA, employer interviewees to this study expressed that communications made

\footnotetext{
${ }^{397}$ Interview with Alaister Duncan, SFWU Central Region Secretary (Julie Polakoski, 17 September 2010) transcript held by author.

${ }^{398}$ Interview with Mediation Service (Julie Polakoski, 14 October 2010) transcript held by author.
} 
during bargaining is the most problematic area for them. Many employers complained that the biggest issue for them has been not being able to communicate to employees what their offer has been to the union during bargaining, even if they claim they are only trying to communicate facts. Whether a union has accurately informed its constituents about the progress made during negotiations and whether an employer may step in to inform the members of its staff about developments in bargaining, as revealed in the interviews conducted for this study, has been a source of contention.

At the same time, unions still experience problems with employers making intimidating comments to union members once bargaining has commenced, deterring union activity. Because joining a union can sometimes be perceived as something an employer would not want of its employees, unions are particularly vulnerable to the effect the employer's comments have on members of its staff. Unions are fearful that if employers are not restricted from communicating to union members during bargaining, the floodgates will be opened for much more employer anti-union tactics. Additionally, in also being bound to the duty of good faith in their relations with their members, unions see allowing employers to communicate to these members of its staff during bargaining about bargaining as unnecessary.

While employers would like to see the law clarified, unions have concerns that this could result in a slippery slope of bad faith behaviour from employers intimidating workers regarding their union activities. The responses to these interviews reveal that a delicate balance needs to be reached regarding good faith communications to employees during bargaining because currently, the parties are unclear about the requirements under the law or feel unsettled about what is permitted and what could be permitted if the law is reformed. 


\section{Sending uninformed representatives to the bargaining table}

In order to engage in genuine, meaningful bargaining, the parties at the bargaining table need to have a basic understanding of the duty of good faith, the issues at hand at the bargaining table, and the process that needs to be followed. Accordingly, it could be held that a party is not acting in good faith if it does not send a representative to the bargaining table who is capable of engaging in an informed discussion of the matters at hand during bargaining.

Parties were not specifically asked if their bargaining counterparts sent uninformed representatives to the bargaining table. Instead, parties were asked generally about the problems that they have had during bargaining. Of the 24 interviews conducted for this study, the NZNO was the only participant who volunteered information regarding this undermining bargaining tactic.

The NZNO has dealt with a private-sector employer who, after the good faith reforms, still engaged in "overtly, savagely anti-union" tactics such as sending a representative to the table who knew nothing about the sector. NZNO does not have a good relationship with this employer and union density is relatively low at the worksite.. The union commented that,

...it was just pointless in having any dialogue with him because he honestly did not know what we were talking about. That was a deliberate strategy by the employer.

Because the representative was incapable of engaging in meaningful bargaining, a breach of good faith should have been apparent. Yet, the NZNO did not seek a remedy for a breach of good faith because it did not believe that the employer's actions would be seen as being in bad faith. ${ }^{399}$

Kevin McFadgen of the NZDHB did not have problems with the union bringing an uninformed representative to the table, but tries to prevent such behaviour on its own

${ }^{399}$ Interview with NZNO officials (Julie Polakoski, 14 June 2010) transcript held by author. 
behalf. Management personnel with Health Employer tend to change jobs every few years whereas union officials tend to stay with the union for most of their career. In order to avoid any confusion during bargaining, McFadgen stated that they have,

... allocated the documents to certain people and they'll be the ones working with that document while they stay with our organisation. I've been doing this with the union for three and a half years, and I'll continue doing it while I'm here so there's continuity on our side. Also, I understand the past issues that have happened and gives continuity across the table as well with the union.

NZDHB was the only employer who reported that they try to maintain this relationship with bargaining representatives so that the parties involved are the most knowledgeable about their dealings. ${ }^{400}$

Although this was not a commonly cited problem in this study, it should not be concluded that it is or is not a problem for collective bargaining parties. The problem does exist and could perhaps be reported as more widespread had the interviewees been specifically questioned about this type of behaviour. Alternatively, if this were a particularly problematic area for many, the parties might have also been more vocal in volunteering information regarding their experiences with this type of bad faith behaviour since it clearly would frustrate the bargaining process. This study at least reveals that this behaviour still occurs in collective bargaining even though the duty of good faith discourages it.

\section{Continuing Bargaining after Reaching an Impasse on an Issue}

In requiring the parties to act in good faith, the process requirements of the ERA set forth provisions in which the parties can more efficiently move along in bargaining. In interpreting these provisions, the code of good faith provides:

Even though the parties have come to a standstill or reached a deadlock about a matter, they must continue to meet, consider and respond to each other's proposals on other matters.

${ }^{400}$ Interview with Kevin McFadgen, DHBNZ Employee Relations Specialist (Julie Polakoski, 3 August 2010) transcript held by author. 
Accordingly, parties are expected to move along during an impasse in good faith hopes to resolve the issues in an orderly manner.

Some of the participants to this study were asked whether or not this provision has helped with the bargaining process or the interviewees volunteered information with regards to their experiences with this provision.

Zane Fulljames with NZ Bus commented that even with this requirement, "You don't move onto the next issue. Instead, he stated,

things can roll on that infinitum. If you reach an impasse, the notion of moving onto the next issue is nonsense. You know people get stuck on the impasse and they always collide from there....you fall into a vicious cycle of escalated conflict and that's not helpful to either the employer or the unions or the individuals they represent.

Fulljames stated that this requirement has not remedied the frustrating process of reaching an impasse. ${ }^{401}$

Paul Tolich with the EPMU found this provision to be helpful on an occasion where the union and an employer entered into protracted bargaining for their first agreement together. In moving onto other issues after an impasse, the parties were able to reach a settlement. Tolich also stated that from a practioner's point of view, it has helped the union solve most negotiations. ${ }^{402}$

Andrew Campbell from FinSec stated that in his experience, this requirement just causes employers to disagree with claims and then move on instead of looking at the whole package. While it is valuable to continue to talk about other issues, the downside to the requirement is that is leaves a lot of issues for later, making it harder for the parties to "construct a complete package that is acceptable."

\footnotetext{
${ }^{401}$ Interview with Zane Fulljames, Chief Operating Officer of NZ Bus (Julie Polakoski, 5 August 2010) transcript held by author.

${ }^{402}$ Interview with Paul Tolich, EPMU National Industry Organiser (Julie Polakoski, 16 September 2010) transcript held by author.

${ }^{403}$ Interview with Andrew Campbell, FinSec Campaigns Director (Julie Polakoski 11 June 2010) transcript held by author.
} 
Although none of the parties had particularly positive experiences with this requirement, the continuing dialogue that it requires was valuable to the parties. This is one example in which good faith encourages that parties to remain in communication with one another in an efficient way in order to reach an end result sooner rather than later, even if it does not eliminate the tension created from an impasse entirely.

\section{Protracted Bargaining}

In order to engage in meaningful bargaining, the parties should not do anything to frustrate the process that is not in genuine good faith. Accordingly, such behaviour as rushing through the collective bargaining process or unnecessarily dragging out the process is likely to be seen as a breach of good faith. ${ }^{404}$

The parties were not specifically asked if they have had problems with this type of behaviour. However, the parties were asked to report any problems or ways in which they have seen the duty of good faith breached. Both an employer and a union independently reported during their interviews some issues with the other side engaging in protracted bargaining.

The NZNO reported one case of extreme protracted bargaining with an employer that the union has not been able to establish a good relationship. This employer repeatedly engaged in behaviours aimed at undermining the union's presence at the workplace, including dragging out the bargaining process for three years. A NZNO representative stated that,

Over that time our density fell and fell and fell away because we couldn't strike any relevance...

This was the same employer who sent an uninformed representative to conduct bargaining with the union. Even at the conclusion of the process three years later, the

\footnotetext{
${ }^{404}$ Davenport 119.
} 
NZNO felt like it "got absolutely nowhere" in bargaining. NZNO added that this employer can engage in such bad faith behaviour because the union only has 30 per cent density at this particular workplace, and they have not been able to gain a single member even after the collective agreement was concluded. ${ }^{405}$

Robert Reid with the NDU commented that protracted bargaining is a problem for their union typically when the bargaining relationship is new. Reid gave an example of a fairly new large employer in New Zealand who was "quite aggressive" in attempting to keep the union out. It took 15 months for the parties to reach their first collective agreement after several bitter disputes in the process. However, the following year, the NDU and this employer were able to negotiate a collective agreement in just six days. The relationship progressed over time, which eventually facilitated with the parties not intentionally protracting bargaining. ${ }^{406}$

Even though protracted bargaining was sparsely reported as a breach of good faith, in these two instances, it has occurred where the parties have not yet established a good relationship with one another. This trend is not dissimilar from the other problematic areas discussed by interviewees in this study.

\section{Pass-on of the collective terms and conditions of employment to non-union members of the staff}

Pass-on is the practice in which employers give non-union employees the same terms and conditions of employment as those reached in a collective bargaining agreement. Because pass-on undermines the relevance and strength of the collective, its practice is seen as being a violation of the duty of good faith.

Pass-on undermines the collective in a workplace for several reasons. Pass-on generally has negative implications for building union support and membership. Workers

\footnotetext{
${ }^{405}$ Interview with NZNO officials (Julie Polakoski, 14 June 2010) transcript held by author.

${ }^{406}$ Interview with Robert Reid, NDU General Secretary (Julie Polakoski, 15 June 2010) transcript held by author.
} 
have less incentive to join the union when they are able to receive the same improved terms and conditions as the collective bargaining agreement but without having to pay union dues. For this reason, pass-on also gives the impression that having a union at a workplace is less relevant. When union membership declines due to pass-on, the union also loses potential resources through union dues that could be used to organise.

Although pass-on is not permitted while bargaining is taking place, the practice is still common as soon as bargaining has concluded. The participants to this study were asked whether or not pass-on has been a problem in their employment relations since the enactment of the ERA. Most interviewees had opinions regarding the matter, and those views varied significantly between employers and unions.

(a) Union opinions regarding pass-on

Many of the union participants to this study expressed some hostility towards the practice of pass-on. Additionally, many also expressed frustration with the remedies provided in the ERA and the Amendment Act. However, some trade unionists now take the position that pass-on spreads the wealth of benefits to all workers, not just the select few who have joined the union; so to them, it is better to benefit all workers and raise the bar for all.

The CTU recognizes the union movement's problem with pass-on, in addition to the animosity it causes for union members:

"It's a big issue for union members. They resent it. So they're in a workplace, they're paying fees, they have often struggled in one way or another and been on strike, and then the employer, of course, offers it to everybody else because if they don't offer it to everybody else, they'll join the union and get the agreement because that's what the law says. So the incentive for the employer to pass on is very strong, The worker can get it anyway by joining the union, so why not pass it on and try to discourage them and keep the workforce de-unionised and split?” 
The CTU recognises that pass-on is an issue that union members are quite "passionate about" and should be resolved. ${ }^{407}$

The NZNO has mostly had problems with pass-on with private sector employers. The union commented,

...it's absolutely endemic in residential age care that passing on will happen to some degree or another, and we haven't been able to succeed in getting a bargaining fee clause into our collective agreements

The NZNO also added that the threshold to bring a case for a breach of good faith regarding pass-on are too high, stating, "we can’t meet those tests nine times out of ten." In workplaces where the NZNO's density is quite low, the union is not able to gain any membership because of pass-on. ${ }^{408}$

According to Andrew Campbell with FinSec, pass-on is "the major issue" for their members, and "it is the biggest barrier to people joining the union." Potential members to the union state, "'why would I pay a union fee when I know that whatever you negotiate, I'm simply going to get. I might as well save myself the $\$ 17.50$ a fortnight because I'm going to get it." Campbell also added that pursuing a case for a breach of good faith with regards to pass-on is pointless because the threshold is too high. For instance, when an employer makes offers to its employees just a few weeks prior to bargaining commences, making it clear that it intends to offer the union-members the same, the threshold for bringing a case for a breach of good faith is two-fold: the union must prove that both the employer undermined the bargaining and the employer acted with the intent to undermine bargaining. FinSec commented that having to prove intent is such a high evidentiary threshold that the union will not waste its resources on this legal remedy. ${ }^{409}$

Campbell claimed that the Amendment Act's effort to restrict pass-on in 2004 "has had zero effect" on their "industry" because the provisions are too weak. To FinSec,

\footnotetext{
${ }^{407}$ Interview with Helen Kelly, CTU President (Julie Polakoski 16 July 2010) transcript held by author.

${ }^{408}$ Interview with NZNO officials (Julie Polakoski, 14 June 2010) transcript held by author.

${ }^{409}$ Interview with Andrew Campbell, FinSec Campaigns Director (Julie Polakoski 11 June 2010) transcript held by author.
} 
the problem with that clause is that it creates an expectation that freeloading won't occur or that freeloading might not be able to occur through some mechanisms to stop it, but there has not been.

FinSec stated that it has only seen one union, the PSA, be able to negotiate a bargaining fee arrangement with their employer to deal with pass-on mostly because that union has high density. However, the rest of the union movement has had no such luck particularly those with low density. Campbell stated that the union has had to raising passing-on as a claim with one employer because it was giving its members the impression that the union is too weak to enforce the provisions around good faith. Not being able to overcome this obstacle undermines the union's credibility with its members. $^{410}$

Alastair Duncan with the SFWU believes that the "symbolism of pass-on is worse than the reality." Duncan understands how irritating it can be for a union to spend so much time in bargaining for its members for the employer to turn around the day after the bargaining has concluded and give the same deal to non-union members. Union members also become angry at this practice because they are paying dues for non-paying members to also reap the benefits. Particularly where the union's density is quite low even as low as 10 per cent - Duncan commented that employers will not have a problem with being able to pass-on. Duncan stated that the union's collective agreement is undermined from the beginning because any new-hire will be given those terms and conditions. $^{411}$

According to NDU General Secretary Robert Reid, "the NDU was very strong in trying to have no passing on. Our policy has changed....we actually don't mind passing on of the bait because we don't want the two-tier system.” The NDU, from a workers rights standpoint, believes that an equal wage structure for everyone in a company is most fair. However, to deal with pass-on under the current legislation, Reid stated that the

\footnotetext{
${ }^{410}$ Ibid.

${ }^{411}$ Interview with Alaister Duncan, SFWU Central Region Secretary (Julie Polakoski, 17 September 2010) transcript held by author.
} 
NDU will always attempt to have a few points of difference in their collective agreements that vary from the individual agreements non-union members have. ${ }^{412}$

Unite organizer Omar Hamed agreed that pass-on is a problem for the Unite union.

We need tougher law and we need enforcement of the law.... what would help Unite is if our big agreements were not passed on. But what are you going to do?

While he admitted that pass-on is a problem, Hamed did not hold the view that pass-on is the biggest obstacle for unions in New Zealand to increase density or improving collective bargaining efforts. "We all hate passing on because it does encourage scabbing and free riding", he stated, "but even so, we want people to be in the union not because they get something more than if they are a non-union member.” Hamed would like to see pass-on restricted under the law, but would prefer people to still join the union for the right reason - that they "believe in unions", not simply because they also want the agreement. $^{413}$

(b) Employer Opinions Regarding Passing-On

Many employers participating in this study took the position that pass-on is done in their workplaces to be fair to all employees. Although they may sympathise with the union's frustrations, many employers engage in pass-on to keep the rest of the workforce happy. However, one employer openly admitted to pass-on as a tactic to keeping union density low.

Finance Employer agreed that the ERA's provisions have not actually helped the situation with pass-on. This employer claimed that it might have helped the union movement, but has not helped employers because employers are still being "threatened with it all the time when all you're trying to do is make sure that everyone is treated fairly.” The majority of this employer's workforce does not belong to a union, yet the

\footnotetext{
${ }^{412}$ Interview with Robert Reid, NDU General Secretary (Julie Polakoski, 15 June 2010) transcript held by author.

${ }^{413}$ Interview with Omar Hamed, Unite Organiser (Julie Polakoski 19 July 2010) transcript held by author.
} 
terms and conditions reached by the collective will be passed-on to the entire workforce. "We know, as an employer, that we will have to offer pay increases at a certain level unless we want all of our staff to go work for our competitors.” When asked whether he thought the employees would simply join the union if passing on were banned, this employer responded,

Maybe. If they didn't get the pay increases, they would either leave or join the union. Some people don't like to join the union for various reasons. If more people here started joining the union, it wouldn't bother us too much.

While he could sympathise with FinSec's frustrations over pass-on, the situation seemed equally frustrating for this employer. ${ }^{414}$

Merchandise employer stated that while pass-on does occurs in its worksite, it will not overtly pass-on without first engaging with the union about it. This employer has agreed with the union to pass-on wages and other terms and conditions of employment to non-union members, but still maintains some differences between the two. This employer stated that because they sit down and discuss the implications of pass-on with the NDU beforehand, there have not been significant issues with the behaviour. ${ }^{415}$

Naturally, Paul Mackay with Business New Zealand could relate to the employers' dilemma with regards to pass-on.

It's hard for anyone to argue that there should be a distinction between unionised and non-unionised workers when they're all doing exactly the same job, so an employer says, 'Well, I've got a workforce of 50 people and 10 of them belong to the union who've come along to bargain collectively for them', and the union then argues that whatever they've reached in settlement of collective bargaining can't then be given to everybody else. And the employer says, 'I've got 50 people. They all have to work together on the same ventures doing the same jobs, and I'm not going to pay them differently just because the law says I can’t pass on.'

\footnotetext{
${ }^{414}$ Interview with Finance Employer (Julie Polakoski, 27 July 2010) transcript held by author.

${ }^{415}$ Interview with Merchandise Employer (Julie Polakoski, 29 September 2010) transcript held by author.
} 
Mackay commented that the law recognizes the reality that pass-on will take place and in fairness, employers will pass-on the same terms and conditions to their entire workforce. ${ }^{416}$

Hospitality Employer stated that although there is some fairness reason for passon, it is more likely that pass-on is a

strategic move by the employer to keep the bulk of the union out of the workplace. So workers are a lot less likely to approach them if they're already getting the benefits passed on.

He added that when the union raised pass-on as a claim against the employer, they were able to get "around it somehow." Here, the employer fully acknowledged that it passedon to undermine the union. ${ }^{417}$

\section{(c) Conclusion regarding passing-on}

Although some employers could sympathise with the problems unions face regarding pass-on, employers and unions held very different perspectives regarding the practice of pass-on. Most unions see the practice as undermining their authority in the workplace and also undermining their role in gaining better wages and conditions for their members. While some trade unionists recognise the benefits in spreading the benefits of a collective agreement to all workers, they did agree that the issue should be addressed. Employers cited issues of fairness but also strategic tactics to undermine the union in admitting to pass-on.

Pass-on is a problem to the labour movement in New Zealand for many reasons. First, pass-on has negative implications for building union support and membership. For younger generations entering the workforce who have had less exposure to the role of unions in employment, it is unlikely that members of these generations will ever realize the role of unions when they continue to reap the benefits of unions without joining.

\footnotetext{
${ }^{416}$ Interview with Paul MacKay, Manager of Employment Relations Policy of Business New Zealand (Julie Polakoski, 27 September 2010) transcript held by author.

${ }^{417}$ Interview with Hospitality Employer (Julie Polakoski, 5 August 2010) transcript held by author.
} 
Second, pass-on is a problem because it gives benefits to an entire workforce with the cost of those benefits being sustained by only a small portion of workers. Resources that could be used to organise on a broader level are lost to the non-union members freeloading. Additionally, in not being able to prevent the practice of freeloading, unions lose some credibility among disgruntled union members who condone the practice.

Pass-on is one area explored in this study that should be addressed by future legal reform. As the law stands now, the parties to an employment relationship are experiencing further industrial unrest and tension due to the practice. From the standpoint of promoting industrial peace and stability, pass-on should be addressed to incorporate both sides' issues with the practice. By addressing the issues surrounding pass-on, legislators would strengthen the duty to engage in good faith behaviour because it continues to be a significant issue of dispute in many workplaces among employees, unions, and employers.

\section{E. Bargaining Fee Arrangements}

If non-union members and the employer agree, the union and employer are permitted to include a bargaining fee arrangement in their collective agreement to require non-union members (whose work falls under the coverage clause of a collective agreement but chose not to join the union) to be given the same terms and conditions of employment as the union-members for a fee paid to the union. ${ }^{418}$

The parties to this study were asked about their opinions regarding pass-on, and accordingly, some volunteered information about negotiating a bargaining fee arrangement. These interviews indicate that it has not been common for unions to be able to reach a bargaining fee arrangement with employers.

Robert Reid with the NDU commented that the union was able to reach a bargaining fee arrangement once. Reid acknowledged that this provision to allow bargaining fee agreements is quite difficult to achieve because non-union members have

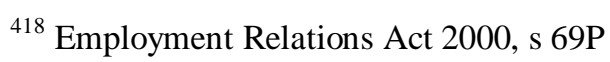


to not only vote, but also must vote in favour of the arrangement. In his experience, nonunion members simply will not bother to vote. ${ }^{419}$

Andrew Campbell from FinSec was not satisfied with the provisions added in the Amendment Act regarding bargaining fee arrangements. He stated that the provision simply has not been a realistic remedy to the problem of pass-on.

Well I don't know what they thought that amendment would actually achieve. I mean it ignores all reality in terms of bargaining, and how a rational employer would behave. Who would actually in their right mind think that by passing a piece of law that says the way to which you to stop freeloading to put up a claim at bargaining asking the employer to hold a bargaining fee ballot which they can say no to and there is no obligation for them to say yes to would resolve that issue? It just blatantly doesn't....

For start, one, the employer has to agree in terms of the bargaining fee which is the mechanisms the act sets up to deal with it.... Well, they can simply refuse to. Secondly, you then have to have a ballot, which you then would have to go run a campaign to win. And then thirdly, even if you win, there is an opt-out provision.

Campbell cited a case in which a union and employer agreed to a bargaining fee arrangement, only to find that the employer the next day put up posters in all the employee tearooms "explaining the provisions for how people opt out of the bargaining fee arrangement." So to FinSec, "the clause is so toothless, it is simply not worth pursuing, particularly...for unions which have less than majority density.” Because much of the private sector has such low density, not being able to negotiate a bargaining fee arrangement will be a common problem. ${ }^{420}$

Alastair Duncan with the SFWU commented that a bargaining fee arrangement was reached with them, the NZNO, and a public sector employer. The union attempts to convince workers paying a bargaining fee that since they are already paying, they might as well opt to also gain the benefits of having full union representation. ${ }^{421}$

\footnotetext{
${ }^{419}$ Interview with Robert Reid, NDU General Secretary (Julie Polakoski, 15 June 2010) transcript held by author.

${ }^{420}$ Interview with Andrew Campbell, FinSec Campaigns Director (Julie Polakoski 11 June 2010) transcript held by author.

${ }^{421}$ Interview with Alaister Duncan, SFWU Central Region Secretary (Julie Polakoski, 17 September 2010) transcript held by author.
} 
Finance Employer was also sceptical of the effectiveness of bargaining fee arrangements as a remedy to the problems with passing-on. He added, "I don't think it's worked, and I don’t think that many employers or unions really use it.” However, this employer also commented that he did not know what the answer could be to this issue. ${ }^{422}$

Overall, parties were unsettled about the effectiveness of the bargaining fee provisions in the 2004 Amendment Act. In practice, the provisions have not been effective in providing a realistic remedy for pass-on. Bargaining fee arrangements have been reached with public sector employers that the union has established a good working relationship and high union density.

\section{F. Requirement to Conclude a Collective Agreement}

The Employment Relations Amendment Act of 2004 attempted to strengthen good faith in collective bargaining by requiring that the union and employer conclude a collective agreement unless there are 'genuine reasons', based on 'reasonable grounds', not to. Grounds that have been defined as unreasonable include opposing the principle of collective agreements or disagreeing over the inclusion of a bargaining fee clause in a collective agreement. $^{423}$

To determine whether or not this provision has been successful in safeguarding collective bargaining, several participants to this study were asked whether or not the requirement to conclude a collective agreement has been helpful, effective, or meaningless.

A representative from the Department of Labour Mediation Services believes that the requirement to conclude an agreement was a positive addition to the ERA. In his

\footnotetext{
${ }^{422}$ Interview with Finance Employer (Julie Polakoski, 27 July 2010) transcript held by author.

${ }^{423}$ Employment Relations Amendment Act 2004, s 33.
} 
experience, this requirement made under the 2004 Amendment strengthened good faith because before, there was an even higher risk that the parties would not conclude an agreement and bargaining would be fruitless. ${ }^{424}$

\section{Employer Opinions Regarding the Duty to Conclude an Agreement}

Employers held the opinion that this requirement has not significantly altered the parties' behaviour at the collective bargaining table. If the parties have a hostile relationship, that relationship will extend for some time. Additionally, this requirement has a loophole that employers believe can and will be used to avoid the conclusion of an agreement.

A financial sector employer commented that the provisions added by the Amendment Act in 2004 including the duty to conclude an agreement were not helpful, and "probably made things more uncertain." This employer thinks that the system worked better with the basic framework set forth in the original ERA enacted in 2000. With regards to the obligation to conclude a collective agreement, this employer's representative stated that he did not think that it made much of a difference. He stated that he thinks "people are mindful of it" and it may have made "a difference in some ways.” For instance, if bargaining reaches a standstill, he said that the parties will typically remind each other of this obligation. ${ }^{425}$

Business New Zealand believes that, "In an ideal world, the employer organisations, ourselves included, would say that you should work in good faith towards an agreement, but if you can't, you can't.” Business New Zealand stated that if an employer does not want to have a collective agreement, reasons for not having one can still be found without being in breach of this requirement to conclude a collective.

...why bother putting that there unless you are to go to the full Monty and say, if a union initiates bargaining and lays claims for one, you shall conclude a collective

\footnotetext{
${ }^{424}$ Interview with Mediation Services (Julie Polakoski, 14 October 2010) transcript held by author.

${ }^{425}$ Interview with Finance Employer (Julie Polakoski, 27 July 2010) transcript held by author.
} 
agreement based on your resolution of those claims. But as long as you provide a loophole, people will use the loophole.

Business New Zealand takes the position that defining a philosophical objection as not being reasonable grounds to conclude a collective agreement will not prevent employers fundamentally opposed to unionisation from covering up their motive for withholding at the bargaining table from concluding. ${ }^{426}$

Zane Fulljames with NZ Bus commented that provisions such as this will not prevent the process from taking a very long time if the parties have a difficult relationship. Parties can still "fall into a vicious cycle of escalated conflict” despite the good faith requirement to conclude. ${ }^{427}$

\section{Union Opinions Regarding the Duty to Conclude an Agreement}

The union participants have had limited success with this duty to conclude in their experiences with collective bargaining. However, the legitimisation of bargaining that such a duty provides has been valuable for unions.

Andrew Campbell with FinSec stated that he has not seen a lot of evidence that employers have changed their behaviour at the bargaining table with regards to this requirement under the Employment Relations Amendment Act 2004. In fact, Campbell has not had positive experiences with this provision.

If anything, what is means is that we might be at the table a bit longer, that they will do things to make sure that they cover their asses in relation to that clause. So they will be clear that they formally respond to each of the claims and give their justification and rationale and all of those sorts of things.

Campbell commented that employers are superficially happy to continue meeting over bargaining, but rarely their positions will change. Campbell has experienced employers to

\footnotetext{
${ }^{426}$ Interview with Paul MacKay, Manager of Employment Relations Policy of Business New Zealand (Julie Polakoski, 27 September 2010) transcript held by author.

${ }^{427}$ Interview with Zane Fulljames, Chief Operating Officer of NZ Bus (Julie Polakoski, 5 August 2010) transcript held by author.
} 
now be "quite expert" in ensuring that their minimum obligations are met under good faith without engaging in meaningful bargaining. Instead of taking a blatant take-it-orleave-it approach, employers are simply doing so in effect; the means for FinSec to get employers to change their offers has been through industrial action, running a campaign, etc., as opposed to relying on good faith. ${ }^{428}$

For the NZNO, union density is a better indicator of whether or not bargaining will conclude with an agreement as opposed to this requirement under the law to conclude. In bargaining with "an overtly savagely anti-union” employer in the past, the NZNO stated that the process took three years and still the parties did not get anywhere. While the employer dragged out bargaining, the union's membership numbers declined because the employer made the union's role in the workplace less and less relevant by engaging in undermining tactics. The employer sent personnel to bargain with the union who had no knowledge of the process or the workings of the sector. This particular employer dealing with the NZNO treated collective bargaining as a joke; the requirement to conclude an agreement unless reasonable grounds not to exist did not ensure an outcome because the employer was so anti-union, it found reasons for years to drag out the process. ${ }^{429}$

The PSA has also encountered similar problems in bargaining and overall, has not seen this requirement to conclude an agreement as a particularly efficient catalyst for an outcome. PSA union organizer Jim Jones commented that, "at the end of the day, the parties have to voluntarily come to an agreement” and although industrial pressure is an option to achieve this goal, good faith has not been, in his experience, a guarantee that the union will be able to reach a collective bargaining agreement with an employer. ${ }^{430}$

When asked if the requirement to conclude has been helpful to the TEU, organiser answered, “I don’t think so, no, because if they don’t want to be agreeable with you, it

\footnotetext{
${ }^{428}$ Interview with Andrew Campbell, FinSec Campaigns Director (Julie Polakoski 11 June 2010) transcript held by author.

${ }^{429}$ Interview with NZNO officials (Julie Polakoski, 14 June 2010) transcript held by author.

${ }^{430}$ Interview with Jim Jones, PSA Organiser (Julie Polakoski, 20 July 2010) transcript held by author.
} 
gives them just another line of defence.” Similar to his union colleagues’ opinions, whether or not the union has a good relationship with an employer is a better indicator of an outcome than this requirement under the Act. ${ }^{431}$

CTU President Helen Kelly commented that the ERA and the Amendment Act are process-focused, not outcome-focused laws. Thus, Kelly did not agree with negative comments from the union-side about this requirement to conclude a collective agreement; Kelly takes the position that provisions such as these are progress for the union movement. $^{432}$

The SFWU was appreciative of the amendment to conclude an agreement. Alistair Duncan expressed that it was a positive change in the law.

I think what it does is it usefully sends a signal that collective bargaining is a statutory right remembering that for ten years in the 1990s, it was silent on it. And it gives you the opportunity to engage with an employer and say in principle, 'What are you here to do?' Now, a clever employer and a clever advocate will say to you, 'Well of course I am here to conclude a collective agreement...'

Although Duncan emphasised that the terms and conditions in the collective agreement really are the focal point of the whole collective bargaining process, the inclusion of this obligation under the law to conclude can only be an improvement from the ECA days. ${ }^{433}$

Robert Reid from the NDU commented that although the union was supportive of the amendment, it's difficult to know if it has helped. Although his experience with this requirement “certainly hasn’t been negative”, the union has yet to see it make a substantial difference. Reid believes that it's only been a small part of the law in trying to reinforce the process of collective bargaining. ${ }^{434}$

\footnotetext{
${ }^{431}$ Interview with TEU Union Organiser (Julie Polakoski, 17 June 2010) transcript held by author.

${ }^{432}$ Interview with Helen Kelly, CTU President (Julie Polakoski, 16 July 2010) transcript held by author.

${ }^{433}$ Interview with Alaister Duncan, SFWU Central Region Secretary (Julie Polakoski, 17 September 2010) transcript held by author.

${ }^{434}$ Interview with Robert Reid, NDU General Secretary (Julie Polakoski, 15 June 2010) transcript held by author.
} 


\section{Conclusion Regarding the Duty to Conclude an Agreement}

Both employers and unions expressed some dissatisfaction with the duty to conclude a collective agreement unless reasonable grounds exist not to. By itself, this requirement has not in practice been very effective in pushing the collective bargaining process along. For instance, some Unions have found that a good relationship with the employer and/or high union density in a worksite are better indicators that collective bargaining will conclude than this duty under the Act. The employers and unions who had established good working relationships with their bargaining counterparts did not contribute about this provision; one reason could be that the good relationship has not necessitated the parties to rely on this requirement.

\section{G. Post-Bargaining Requirements}

Section 62 of the ERA requires an employer to tell new employees that a collective agreement exists and that the type of work the employee will be engaging in is covered under that agreement, in addition to other details about the union should the employees decide to join the union. Furthermore, section 63 provides that for the first 30 days of employment, the new employee will be given the same terms and conditions as the collective agreement, as well as any additional terms and conditions negotiated by the employee and employer that are not inconsistent with the collective.

Andrew Campbell from FinSec stated that employers do follow the "minimum legal requirements" in giving new employees information about the union and explaining that for the first 30 days of their employment, they are covered by the collective agreement. However, in Campbell's experience, most managers are quick to point out to these new employees that they do not have to join the union to get these same terms and conditions of employment. Campbell added,

we think of it as really undermining the good faith provisions immediately, because actually, it is our assessment of those provisions that they have to take a much more neutral stance on that, and that's quite a positional stance from day 1. 
Campbell also reported that FinSec has a lot of issues with employers not passing on a new employee's information who has chosen to have his or her information given to the union. Campbell stated, "we never get the information of people actually seeking for their information to be passed onto the union, so another clear breach.” FinSec will "continually" raise this issue with employers, but in a few weeks, they will stop providing the information again. It has been a "constant battle" for FinSec to get employers to comply with this good faith provision. ${ }^{435}$

Robert Reid from the NDU has found this good faith provision to be quite helpful when employers comply with it. Reid commented that employers will "never" automatically provide the union with the new employee's information once they've made the request to have the information passed along. However, once the employer and the union have gotten past their disputes and established a good working relationship, they will comply with these good faith provisions. ${ }^{436}$

Omar Hamed with Unite has had difficulties with employers complying with this provision. Because Unite organises industries with such high turnover rates like fastfood restaurants, this can be particularly problematic for the union. Employers will typically just give the department the new employee is working in who has requested the union be given their contact information. The union might not be given their contact details, an email address, or a phone number. With some employers, the employer will give the new employee a form asking if they would like to join the union and Unite will then be given those forms, which has been very helpful. ${ }^{437}$

The respondents to this question all seemed to appreciate the requirement for employers to give notice to new employees of their right to join the collective. The practice has been helpful for unions when employers comply with the requirement in good faith.

\footnotetext{
${ }^{435}$ Interview with Andrew Campbell, FinSec Campaigns Director (Julie Polakoski 11 June 2010) transcript held by author.

${ }^{436}$ Interview with Robert Reid, NDU General Secretary (Julie Polakoski, 15 June 2010) transcript held by author.

${ }^{437}$ Interview with Omar Hamed, Unite Organiser (Julie Polakoski 19 July 2010) transcript held by author.
} 


\section{H. Breach of Good Faith Remedies}

\section{Seeking a Legal Remedy}

There have only been a small number of cases that have gone on to test what good faith is since the ERA was enacted in 2000. The interviews conducted for this study revealed several reasons for this. In general, the parties to bargaining are not overtly litigious in New Zealand. Many parties cited a reluctance to engage their collective bargaining counterparts in legal action when a dispute arose regarding good faith.

Most union interviewees commented that any issues will typically be raised with the employer first before pursuing a legal remedy. For instance, in their interview, Finsec stated that, in attempting to not be litigious about these issues, they understand that "one of the good faith obligations is to use low-level resolutions." So they will speak to the employer first before trying to get the Employment Relations Authority involved. ${ }^{438}$

However, just because unions attempt to resolve these issues with the employer first without seeking assistance from the Employment Relations Authority does not necessarily mean that this is an effective means of reaching an outcome. FinSec claimed that when they do raise issues with an employer, the employer will generally attribute the behaviour as just the on-site issue with a particular manager as opposed to something that they can control. ${ }^{439}$

A legal remedy is also an undesirable route for both sides because it is not actually an effective remedy for either party. As stated by FinSec,

The best we can do is raise it [the breach of good faith] after the fact. But then it's also for something like that, the damage is already done....we sue them a few months down the track, they issue a thing saying that email we sent a while ago was a breach of good faith...I mean, the effect was that it stopped people feeling

\footnotetext{
${ }^{438}$ Interview with Andrew Campbell, FinSec Campaigns Director (Julie Polakoski 11 June 2010) transcript held by author.

${ }^{439}$ Ibid.
} 
comfortable about talking about joining the union on the day, but I mean the damage had already been done.”

Because of the high cost associated with pursuing a legal remedy, doing so after the damage is done is not ideal. ${ }^{440}$

Employers also typically have more resources going into court than a union. According to Robert Reid with the NDU,

Employers employ legal companies, union busting companies to take the law to its extreme and what they can get away with in each case. And we try not to be litigious as a union. We're prepared to have a go and fight when we need to fight, but also if we get a good relationship with the employer, then we'd actually rather solve all those issues within that relationship rather than running off to a court all the time to make decisions for either us.

Establishing a good relationship is a more desirable remedy for breaches of good faith and difficult bargaining than getting judicial body involved because then, the employer and union can work together for a better collective bargaining agreement in the future. ${ }^{441}$

To the NZNO, winning a case against an employer for a breach of good faith is not as valuable as the union being able to increase density at a worksite. In achieving their desired outcomes in collective bargaining

what matters is density, and the current legislation has not helped us to build density at all in the sector.

The union commented that relying on high union density is more dependable for the union to achieve their desired bargaining outcomes than resorting to legal action. ${ }^{442}$

Employers also cited a reluctance to get the Employment Relations Authority involved when they believe the union has breached the duty of good faith. Their reasoning for not pursuing a legal remedy were similar to that of the union side.

\footnotetext{
440 Ibid.

${ }^{441}$ Interview with Robert Reid, NDU General Secretary (Julie Polakoski, 15 June 2010) transcript held by author.

${ }^{442}$ Interview with NZNO officials (Julie Polakoski, 14 June 2010) transcript held by author.
} 
Finance Employer commented that they filed a case for a breach of good faith against the union before, but ended up settling the matter out of court. Finance Employer also agreed that once the breach of good faith has occurred, the damage is already done. "You can go to court, but they already achieved their purpose. And they would probably say the same thing about us...you can’t undo [the damage].”, the employer stated. ${ }^{443}$

Merchandise Employer also took the position that seeking a legal remedy for a breach of good faith is not desirable.

Often it's a commercial decision and sometimes it's quicker to get on little things rather than front up the money to take a point of view or set a precedent or act upon principal only to try and take it to a point where maybe case law might come out of it. It seems expensive and not worthwhile and not necessarily a good commercial decision to do so.

Merchandise Employer suggested this as the reason why there has not been much case law on good faith in New Zealand, and also possibly as well that no one really understands what good faith means. ${ }^{444}$

Kevin McFadgen with the NZDHB added that he thinks costs and time are reasons why the parties do not pursue legal remedies for a breach of good faith. However, where there have been multiple breaches of good faith, then it is a more realistic remedy. ${ }^{445}$

Overall, the interviewees expressed a reluctance to take their collective bargaining counterparts to the Employment Relations Authority for a breach of good faith because of the costs associated with the process, the increased tensions it may cause, and that a decision cannot change the fact that the damage is already done.

\footnotetext{
${ }^{443}$ Interview with Finance Employer (Julie Polakoski, 27 July 2010) transcript held by author.

${ }^{444}$ Interview with Merchandise Employer (Julie Polakoski, 29 September 2010) transcript held by author.

${ }^{445}$ Interview with Kevin McFadgen, DHBNZ Employee Relations Specialist (Julie Polakoski, 3 August 2010) transcript held by author.
} 


\section{Analysis}

\section{A. Common Themes}

A general trend that emerged from all the surveys conducted for this study was that good faith is not the best determinant that collective bargaining will go smoothly or that the union and the employer will have productive relationships. Additionally, the responses to these interviews revealed that the good faith requirements alone were not a strong determinant that the parties’ collective bargaining rights will be preserved. Rather, a good relationship between an employer and union and high union density at a worksite are better determinants that collective bargaining will be productive and meaningful. The following are the two most common trends cited by respondents in explaining when good faith is effective.

\section{Good Relationship Significant Factor for Collective Bargaining}

The parties who reported the least amount of issues surrounding compliance with the good faith provisions had established good relationships with their bargaining counterparts. Although good faith was enacted to facilitate good employment relationships, all parties who had good relationships with their employment counterpart agreed that such relationships were established independent of good faith. Parties who have struggled to maintain good terms with their bargaining counterparts cited the most breaches of good faith.

Unsurprisingly, an employer with the goal of keeping the union out of its worksite is unlikely to utilize good faith to promote a productive relationship with its union counterparts. Organizer Omar Hamed with Unite observed that good employers,

"talk back about good faith and use it to create an employment relationship that works for everyone. But nasty employers will tangle you up in good faith and attempt to use it to undermine collective bargaining....so good faith, I think, is useful when you're dealing with good employers, but when you reach a nasty employer it doesn't mean anything because they'll do any dirty trick in the book. And even decent employers, if they want to, they will ignore it." 
Hamed has found good faith to be utilised the most by employers who "want their workplace to be a good place to work." Hamed's experience was not unique to the Unite union. $^{446}$

On the other hand, unions will also breach the duty of good faith when the collective bargaining relationship is hostile. According to Zane Fulljames with NZ Bus, when the parties at the bargaining table do not have a good relationship with one another, it has been his experience that good faith is rarely used as a tool to help ease tensions and resume productive bargaining. This employer stated that good faith has, in some instances, been used as a "lever to create industrial conflict" and historically in some environments, it’s been a device "to kick off a dispute.” In his experience, good faith has been "real easy to throw it around" as a weapon when the parties are not in agreement, not a source for resolution. ${ }^{447}$

Organiser Jim Jones from the PSA agreed with this trend, adding that these "core factors....probably influence outcomes...regardless of the environment.” Kevin McFadgen from the NZDHB cited the least amount of bargaining problems with the NZNO, a union with whom the employer has established a good working relationship. The Meatworkers Union and its Meat Industry Employer bargaining counterpart both reported that the good faith reforms neither hurt nor helped collective bargaining for them mostly because the parties had established a good working relationship with one another long ago. ${ }^{448}$

Accordingly, where the parties to collective bargaining have not yet been able to establish a good working relationship with one another, the duty of good has had minimal impacts on the facilitating the bargaining process and ultimate outcome. However, where the parties are already on good terms and perhaps even engaging with one another in good faith, the law again has had minimal impacts on behaviour.

\footnotetext{
${ }^{446}$ Interview with Omar Hamed, Unite Organiser (Julie Polakoski 19 July 2010) transcript held by author.

${ }^{447}$ Interview with Zane Fulljames, Chief Operating Officer of NZ Bus (Julie Polakoski, 5 August 2010) transcript held by author.

${ }^{448}$ Interview with Jim Jones, PSA Organiser (Julie Polakoski, 20 July 2010) transcript held by author.
} 


\section{High Union Density Significant Factor for Collective Bargaining}

High union density was also cited as a significant factor in whether the parties were able to engage in efficient and meaningful collective bargaining. Most interviewees who were bargaining with an employer with high union density also had established a good working relationship with their collective bargaining counterpart. Alternatively, where unions have high union density, they have been better able to achieve their collective bargaining goals without the assistance of good faith. Employers are perhaps more compliant with the union's demands when the threat of a strike exists for the majority of their workers. On the other hand, where a union has high density and a poor rapport with the employer, the relationship can be quite volatile in light of the severe industrial action capabilities of the union.

(a) Union Opinions of the Benefits of High Density to Collective Bargaining

The advantages for a union with high density and the power balance it is able to achieve were explained by the NZNO.

Good faith works fine where we've got density so that we can enforce a reasonable request by industrial action if we have to in bargaining.

While the NZNO argues that the current legislation has not been helpful for the union to achieve higher density due to problems with pass-on, the union is able to rely on the same strategies it always has.

The thing that's helped us build density is the same old same old; it's having people in workplaces at night and in the weekends when the boss isn't there, talking to them, signing them up, looking for an issue that we can have a victory on, making the union relevant, establishing relationships with workers in the workplace so that people trust us and are willing to work with us and can see the benefit of working with us.

Devoting resources and time towards organising in order to establish high density has been far more valuable for the NZNO than the duty of good faith. ${ }^{449}$

\footnotetext{
${ }^{449}$ Interview with NZNO officials (Julie Polakoski, 14 June 2010) transcript held by author.
} 
Andrew Campbell of FinSec also stated that it's difficult to enforce the good faith provisions when the union has low density at a worksite. Yet, with pass-on being so common in the private sector, it is unlikely that density will rise. ${ }^{450}$

The Meatworkers Union also agreed that high density is more helpful in combination with a good relationship with an employer in achieving a productive collective bargaining relationship than purely relying on the good faith provisions. ${ }^{451}$

\section{(b) Employer Opinions of the Benefits of High Density to Collective Bargaining}

Some employers also held the opinion that having high union density in a workplace results in smoother collective bargaining than if there is a clear split between unionised workers and non-unionised workers.

Merchandise Employer admitted that he thinks it would "be better there to have it all on one camp or all on the other rather than trying to handle two different camps.” Additionally, he added, from a practical standpoint, communications with employees would be less complicated if they were all unionised or non-unionised. ${ }^{452}$

Kevin McFadgen from the NZDHB also commented that it is more difficult to deal with a workforce that, instead of being heavily unionised, is split between unionised and non-unionised. However, if the majority of the workforce is unionised, they have much more power if they go on strike. ${ }^{453}$

Zane Fulljames with NZ Bus stated that his company is "running a pro-union strategy" because there is "very much a need for unions" in their industry. Because of

\footnotetext{
${ }^{450}$ Interview with Andrew Campbell, FinSec Campaigns Director (Julie Polakoski 11 June 2010) transcript held by author.

${ }^{451}$ Interview with Dave Eastlake, NZ Meat Workers Union General Secretary (Julie Polakoski, 21 September 2010) transcript held by author.

${ }^{452}$ Interview with Merchandise Employer (Julie Polakoski, 29 September 2010) transcript held by author.

${ }^{453}$ Interview with Kevin McFadgen, DHBNZ Employee Relations Specialist (Julie Polakoski, 3 August 2010) transcript held by author.
} 
the type of work involved and the types of workers the busy industry attracts, Fulljames believes that strong advocacy from a union is essential; perhaps this is why 95 per cent of its workforce belongs to the union and has traditionally had high union density. Fulljames added that it prefers having high union density at its worksite if only because the workers need strong representation. ${ }^{454}$

Meat Industry Employer stated that the less people the employer has to bargain with, logistically the better it is. Because Meat Industry Employer has several unions representing its workforce, having so many different people at the bargaining table with so many different agendas can complicate the process. ${ }^{455}$

\section{(c) Conclusion Regarding High Union Density}

All unions participating in this study cited high union density as being a helpful factor in their ability to achieve their collective bargaining goals. At the same time, some employers have added that having high union density in a worksite is preferred more than having a workforce that is split. Most importantly, however, the interviewees to this study revealed that high union density is a better indicator that collective bargaining will go smoothly than the duty of good faith.

\section{Conclusion}

One of the major goals of the ERA was to promote collective bargaining through the duty of good faith. ${ }^{456}$ This study investigated the progress New Zealand has made to achieve this goal in the first 10 years of the ERA from the perspective of those bound to the duty of good faith in collective bargaining. While the reasons for a continued decline in collective bargaining density are complex, the law is an important factor. Accordingly, this study focused solely on the impacts of the good faith reforms on promoting and protecting collective bargaining.

\footnotetext{
${ }^{454}$ Interview with Zane Fulljames, Chief Operating Officer of NZ Bus (Julie Polakoski, 5 August 2010) transcript held by author.

${ }^{455}$ Interview with a Meat Industry employer (Julie Polakoski, 9 September 2010) transcript held by author.

${ }^{456}$ Employment Relations Act 2000, s 3.
} 
The interviewees to this study revealed that the duty of good faith as set forth in the ERA and subsequent legislation has had very limited success in protecting and promoting the collective bargaining rights of workers. This finding affirms the thesis of this study that the protective strength of the duty of good faith is insufficient to promote and protect collective bargaining alone.

This study is in no way, shape, or form suggesting that good faith should be abolished in New Zealand employment law. There was a consensus among the interviewees that the ERA has been an improvement from the ECA and the duty of good faith is a valuable addition to the law. Further, no one expressed a desire to move back to compulsory arbitration or the ECA. Thus, it should be gathered that New Zealand is moving towards providing a more balanced system of industrial relations. Good faith is indeed crucial to achieving the objective of the ERA to promote collective bargaining.

What this study does suggest is that the parties to collective bargaining believe that the good faith reforms have not lived up to expectations. While the ERA represented a change in philosophy than the ECA, the degree of the impacts expected with this change have been limited, particularly in light of declining collective bargaining coverage. The 2004 Amendments have had even less success. In discussing their experiences with good faith in the collective bargaining process, the interviewees’ comments imply that further legislative reform is potentially necessary to strengthen the duty of good faith.

Most of the interviewees to this study agreed that the good faith provisions would be valuable if the parties complied with their requirements in a meaningful way. Both sides of the employment spectrum had problems with the good faith provisions being "toothless."

Good faith has helped most parties increase the flow of information at the bargaining table and put pressure on parties to continue a dialogue towards a collective 
bargaining outcome; however, these benefits only occur when the provisions are followed. Other provisions, as discussed earlier such as the duty to move onto other topics once an impasse is reached on one, are good in theory, but have provided little assistance in practice during bargaining.

As other academic scholars have argued, ${ }^{457}$ this study has also found that while the ERA provides legal support for both unions and collective bargaining, such support is only meaningful where the parties have established a good working relationship and unions have been able to develop a strong membership at the worksite. ${ }^{458}$ The interviewees revealed that the duty of good faith has been complied with most commonly where the parties have been able to establish a good working relationship with one another. However, most parties revealed that the good relationship with their collective bargaining counterpart was established independent of the good faith provisions. Additionally, where the parties have established a good working relationship with one another, the ERA changed little regarding their bargaining.

Where the parties have a hostile collective bargaining relationship, the duty of good faith has done little to ease tensions around the bargaining table or facilitate the process. Instead, the duty of good faith is often used as a tool to kick off a dispute.

Unions have cited high density and a good rapport with an employer as being the two best indicators that collective bargaining will go smoothly and result in a fair collective agreement. For logistical purposes, some employers agreed that having high union density would facilitate bargaining for them. Employers that have established a good relationship with the union also agreed this to be the best indication that bargaining will be efficient and effective.

Part of the problem could be that the New Zealand labour movement has not fully adjusted to operating in a system of competitive unionism. For most of New Zealand

\footnotetext{
${ }^{457}$ Gordon Anderson and Geoff Davenport have suggested this in the articles they have written on the subject.

${ }^{458}$ Anderson, above n 2, at 69.
} 
history, unions did not have to rely on their own organising strength to ensure their existence and membership numbers. Perhaps it is still the case the unions are struggling to exist in a legal system that does not guarantee collective bargaining will occur without the union's ability to organise in a not-spectacularly union-friendly environment.

Another issue may be that New Zealand has not fully learned from the North American experience with the duty of good faith in collective bargaining. In his research, Davenport recommended that mechanisms be put in place to strengthen the duty of good faith, such as arbitration to ensure a settlement for first time collective bargaining partners. He also encouraged New Zealand to impose financial penalties and tailored remedies that could potentially help with the interviewees' concern that the good faith provisions are "toothless.” New Zealand could learn more from Davenport's research suggesting that good faith needs to be strengthened through tailored remedies and harsher penalties.

Pass-on remains a significant reason cited by unions as a cause for declining collective bargaining rates throughout New Zealand. The DoL's study in 2009 found this to be true ${ }^{459}$, and the interviews conducted in this study affirm that this practice remains a problem for unions attempting to increase collective bargaining in New Zealand. As long as pass-on continues in the large numbers that it has been reported to occur, it seems unlikely that the ERA's goal to promote collective bargaining will be realized. Pass-on will also continue to undermine collective bargaining because it allows employers to essentially discourage workers from joining the collective employment agreement.

If legislators are concerned with strengthening the good faith requirements, additional mechanisms will be needed to limit pass-on. As a remedy, a bargaining fee could be imposed every time a term and condition of employment is passed-on. Other mechanisms could be put in place to make it easier prove that pass-on has occurred; for example, the threshold could be lowered to no longer require the employer's intent be

${ }^{459}$ Department of Labour, The Effect of the Employment Relations Act on Collective Bargaining (July 2009) at 6. 
proved when pass-on has occurred after a collective employment agreement has been concluded when bringing a case for a breach of good faith.

Additionally, anyone who has worked in employment relations understands that the law can often have minimal impacts on employment behaviours and relationships. In other words, an anti-union employer will still harbour these sentiments in its relations with the union regardless of the law. However, what the law can do is create an environment which legal mechanisms in place to promote collective bargaining to flourish. Although New Zealand attempted to do this, the ultimate goal does not appear feasible under the current legislation.

Overall, this study has shown that good faith has had little impact on the parties' substantive behaviour during bargaining with even more limited impacts on collective bargaining outcomes. As it currently stands under the law, good faith cannot be relied upon to remedy an uneasy bargaining relationship, resolve a bargaining dispute, or reach a fair bargaining agreement. However, where the parties have established a good working relationship and the union has achieved high density, good faith is followed and the parties are productive. Thus, this study stands for the notion that, in order to strengthen the duty of good faith, perhaps more should be done legislatively to strengthen the environment in which unions and employers can establish good relationships and unions can achieve higher union density. The parties' responses indicate that under the current legislation, the protective strength of the duty of good faith is poor and more should be done to strengthen the provisions. 


\section{Bibliography}

\section{Statutes:}

Employment Relations Act 2000

Employment Contracts Act 1991.

Industrial Conciliation and Arbitration Act 1894.

Freedom of Association and Protection of the Right to Organise Convention ILO C87, 31st conf, (1948)

Right to Organise and Collective Bargaining Convention ILO C98, 32nd conf, (1949)

\section{$\underline{\text { Official Publications }}$}

Department of Labour In Good Faith (June 2005).

Department of Labour Union Membership Return Report 2009 (2009).

Department of Labour The Effect of the Employment Relations Act on Collective Bargaining (July 2009).

Statistics New Zealand. (2008). Labour Market Statistics: 2008. Wellington: Statistics New Zealand.

Swain, Paul Code of Good Faith for Collective Bargaining (prepared for the Department of Labour 2005).

Waldegrave, Tony, Anderson, Diane and Won, K Evaluation of the Short Term Impacts of the Employment Relations Act (Department of Labour 2003).

\section{Cases:}

Assn of University Staff Inc $v$ Vice Chancellor of the University of Auckland [2005] 2 NZELR 277, [2005] 2 (1) NZLR 277.

Christchurch City Council v Southern Local Government Officers Union [2007] 2 NZLR 614 at 623

NUPE v NZ Customs Service [2004] 1 ERNZ 237. 
NZ Amalgamated Engineering Printing and Manufacturing Union $v$ Independent Newspapers Ltd [2001] 6 NZELC 96.

NZ Amalgamated Engineering Printing and Manufacturing Union $v$ Independent Newspapers Ltd [2001] 6 NZELC 96.

National Distribution Union Inc. v General Distributors Ltd [2007] 4 NZELR 215, [2007] 4(1) NZELR120.

The New Zealand Public Service Association v Secretary for Justice [2010] 11 NZEMPC WRC 54/09.

Griffin v Attorney-General [1995] 4 NZELC (digest) 98, 317 (EC)

New Zealand Air Line Pilots Assn IUOWv Air New Zealand Ltd [1998] 3 ERNZ 332.

\section{Books:}

Anderson, Gordon "New Zealand” in R. Blanpain (ed) International Encyclopaedia of Laws (Kluwer Law International, Alphen aan den Rijn, 2006].

Blumenfeld, Stephen "Collective Bargaining” in Erling Rasmussen (ed) Employment Relationships: Workers, Unions, and Employers in New Zealand (new ed, Auckland University Press, Auckland 2010) 40 - 55.

Blumenfeld, Stephen, Ryall, Sue and Kiely, Peter Employment Agreements: Bargaining Trends and Employment Law Update 2009/2010 (Victoria University of Wellington Industrial Relations Centre, Wellington, 2010).

Burton, Barbara "Employment Relations 2000 - 2008: An Employer View” in Erling Rasmussen (ed) Employment Relationships: Workers, Unions and Employers in New Zealand (new ed, Aukland University Press, Auckland, 2010) 94-115.

Dannin, Ellen J. Working Free: The Origins and Impact of New Zealand's Employment Contracts Act (Auckland University Press, Auckland, 1997).

Davenport, Geoff and Brown, Judy Good Faith in Collective Bargaining (LexisNexis Butterworths, Wellington, 2002).

Engels, Chris and Brooks, Brian Trade Unions in the 1980's: Some Lessons for the Future (Industrial Relations Monograph Series, The University of New South Wales, 1990).

Gross, James A. Workers' Rights as Human Rights (Cornell University Press, Ithica, 2003). 
Rasmussen, Erling Employment Relations in New Zealand (2nd ed, Pearson, North Shore (New Zealand), 2009).

Rudman, Richard Employment Law Guide (2010 ed, CCH, Auckland, 2010).

Vranken, Martin Death of Labour Law: Comparative Perspectives (Melbourne University Press, Melbourne, 2009).

Journal Articles:

Anderson, Gordon ““The Sky Didn’t Fall In’: An Emerging Consensus on the Shape of New Zealand Labour Law? (2010) 23 Australian Journal of Labour Law 94 - 120.

Anderson, Gordon "Transplanting and Growing Good Faith in New Zealand Labour Law" (2006) 19(1) Australian Journal of Labour Law 1-29.

Anderson, Gordon "The Individual and the Employment Relations Act" (2001) 26(1) New Zealand Journal of Industrial Relations 103-118.

Anderson, Gordon "Just a Jump to the Left? New Zealand's Employment Relations Act 2000" (2001) 14 Australian Journal of Labour Law 62-88.

Anderson, Gordon "Collective Bargaining and the Law: New Zealand's Employment Contracts Act Five Years On" (1996) 9 Australian Journal of Labour Law 103-134.

Anderson, Gordon and P Walsh "Labour's New Deal: A bargaining framework for a new century?" (1993) 18(2) New Zealand Journal of Industrial Relations 163-176.

Anderson, Gordon "Developments in the Legal Regulation of Collective Bargaining in New Zealand" (1990) 3(3) Australian Journal of Labour Law 227-246.

Anderson, Gordon "The Employment Contracts Act 1991: An employers charter?" (1991) 16 New Zealand Journal of Industrial Relations 127-142.

Anderson, Gordon and Brosnan, P. "Freedom of Association: New Zealand and ILO Convention 87." (1984) New Zealand Law Journal 307-310.

Dannin, Ellen J. “We Can’t Overcome? A Case Study of Freedom of Contract and Labor Law Reform” (1995) 16(1) Berkeley J. Empl. \& Lab. L. 3 - 168.

Davenport, Geoff "The Legal Obligation to Bargain in Good Faith in the New Zealand Labour Market: Rhetoric or Reality” (1999) 24(2) NZJIR 119-158. 
Davenport, Geoff "Approach to Good Faith Negotiations in Canada: What Could be the Lessons for Us?” (2003) 28 (2) New Zealand Journal of Industrial Relations 150 -156.

Foster, Barry and McAndrew, Ian "Growth and Innovation Through Good Faith Collective Bargaining: An Introduction to the Conference Collection” (2003) 28(2) New Zealand Journal of Industrial Relations $118-121$.

Latornell, Jamie "Uncovering the Origins of New Zealand's Employment Relations Act 2000: A Research Framework” (2006) 31 (3) NZJER 88 - 100.

Walsh, Pat "The Employment Contracts Act" in Jonathan Boston \& Paul Dalziel (eds) The Decent Society? Essays in Response to National Economic and Social Policies (Oxford University Press, Auckland, 1992).

Wilson, Margaret “The Employment Relations Act: A Framework for a Fairer Way" (2001) 26 (1) New Zealand Journal of Industrial Relations 9 - 20.

\section{Interviews}

Interview with Andrew Campbell, FinSec Campaigns Director (Julie Polakoski 11 June 2010) transcript held by author.

Interview with NZNO Union Officials (Julie Polakoski, 14 June 2010) transcript held by author.

Interview with Robert Reid, NDU General Secretary (Julie Polakoski, 15 June 2010) transcript held by author.

Interview with PSA Legal Advisor (Julie Polakoski, 17 June 2010) transcript held by author.

Interview with TEU Union Organiser (Julie Polakoski, 17 June 2010) transcript held by author.

Interview with Andrew Casidy, FinSec General Secretary (Julie Polakoski 28 June 2010) transcript held by author.

Interview with Helen Kelly, CTU President (Julie Polakoski, 16 July 2010) transcript held by author.

Interview with Omar Hamed, Unite Organiser (Julie Polakoski 19 July 2010) transcript held by author. 
Interview with Jim Jones, PSA Union Organiser (Julie Polakoski, 20 July 2010) transcript held by author.

Interview with Finance Employer (Julie Polakoski, 27 July 2010) transcript held by author.

Interview with Paul McKay, Manager of Employment Relations Policy of Business New Zealand (Julie Polakoski, 27 July 2010) transcript held by author.

Interview with Business New Zealand Official (Julie Polakoski, 27 July 2010) transcript held by author.

Interview with Kevin McFadgen, DHBNZ Employee Relations Specialist (Julie Polakoski, 3 August 2010) transcript held by author.

Interview with Hospitality Employer (Julie Polakoski, 5 August 2010) transcript held by author.

Interview with Zane Fulljames, Chief Operating Officer of NZ Bus (Julie Polakoski, 5 August 2010) transcript held by author.

Interview with Government Agency Employer (Julie Polakoski 31 August 2010) transcript held by author.

Interview with Meat Industry Employer (Julie Polakoski, 9 September 2010) transcript held by author.

Interview with Paul Tolich, EPMU National Industry Organiser (Julie Polakoski, 16 September 2010) transcript held by author.

Interview with Alaister Duncan, SFWU Central Region Secretary (Julie Polakoski, 17 September 2010) transcript held by author.

Interview with Nick Kelly, Wellington Tramways Union President (Julie Polakoski, 28 September 2010) transcript held by author.

Interview with Mediation Services (Julie Polakoski, 14 October 2010) transcript held by author,

\section{Electronic Resources:}

District Health Boards New Zealand

$<$ http://www.dhbnz.org.nz/Site/DHBNZ/Default.aspx>.

EPMU < http://www.epmu.org.nz/>. 
FinSec <http://www.finsec.org.nz>.

New Zealand Bus < http://www.nzbus.co.nz/who-are-we.php>.

New Zealand Council of Trade Unions <http://union.org.nz/about/ctu-affiliates>.

New Zealand Meat Workers and Related Trades Union Inc. < http://www.nzmeatworkersunion.co.nz/our_history.html>.

New Zealand Nurses Organisation <http://www.nzno.org.nz/about_us>.

New Zealand Public Services Association <http://psa.org.nz>.

Marcela Escauriaza “New Zealand: Unite Takes on Minimum Wage” (2010) Green Left $<$ http://www.greenleft.org.au/node/43155>.

Service and Food Workers Union Nga Ringa Tota <http://www.sfwu.org>.

Tertiary Education Union <http://teu.ac.nz/about/history/>.

Unite <http://www.unite.org.nz/node/165>. 